\begin{tabular}{|c|l|}
\hline Title & Hydrography of the A rctic Ocean with Special Reference to the Beaufort Sea \\
\hline Author(s) & KUSUNOKI, Kou \\
\hline Citation & Contributions from the Institute of Low Temperature Science, A 17, 1-75 \\
\hline Issue Date & 1962-12-20 \\
\hline Doc URL & http://hdl.handle.net/2115/20226 \\
\hline Type & bulletin (article) \\
\hline File Information & A17_p1-75.pdf \\
\hline
\end{tabular}

Instructions for use 


\title{
Hydrography of the Arctic Ocean with Special Reference to the Beaufort Sea*
}

\author{
by \\ Kou KUSUNOKI \\ 楠宏 \\ Oceanographic Section, The Institute of \\ Low Temperature Science
}

Received August 1962

\section{Contents}

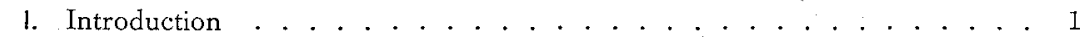

II. General background of the oceanographical studies in the Arctic Ocean . 2

III. General account of the ice islands . . . . . . . . . . . . 7

IV. Instrumental and observational aspects of the work at Ice Island T-3 in $1959-1960 \ldots \ldots \ldots \ldots \ldots$

V. Distribution of temperature ................... 13

VI. Distribution of chlorinity and density . . . . . . . . . . 32

VII. Distribution of chemical elements . . . . . . . . . . . . . 38

VIII. Water masses in the Arctic Ocean . . . . . . . . . . . . . . 49

IX. Circulation in the Arctic Ocean . . . . . . . . . . . . 63

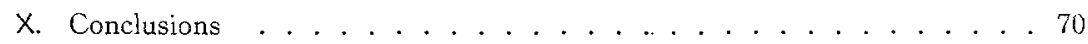

Acknowledgments . . . . . . . . . . . . . . 73

References ......................... 73

1. Introduction

This paper is intended to provide a knowledge of the Arctic oceanography, particularly of the northern portion of the American continent where the oceanographic data are still extremely sparse, especially winter observations. Actually the Arctic Ocean held a number of unsolved problems when H. U. SvERDRUP (1950) prepared his review of physical oceanography in 1950. He emphasized the poverty of information concerning the character of waters which had been studied only on the Siberian. European side of the Arctic Ocean. Since the late 1940's oceanographic observations in the Arctic Ocean have become very active with the aid of aircraft landed on the Arctic pack ice. The shipboard observations were inevitably constrained within the coastal waters.

In former days oceanographic observations in the central part of the Arctic Ocean were made from icebound ships, some of which were caught in the ice with deliber-

* Contriubtion No. 628 from the Institute of Low Temperature Science. 
ation, such as the drift of the Fram in 1893-1896. Since World War II a number of expeditions with the aid of aircraft have been sent to the central part of the Arctic Ocean to work in parallel with the shipboard observations at the coastal waters. Drift stations on the ice floes which have served as oceanographic research vessels have been established in the central Arctic. Putting aside the activities of these stations in the early part of 1950 's, the situation during the International Geophysical Year will be worthy of note. Four drift stations on ice were in operation during the IGY, of which two were on the Arctic pack ice and two were on the "ice island" with greater thickness than the pack ice. The Soviet maintained two stations (designated SP-6 and SP-7)* while the United States established Drift Station Bravo on "Ice Island T-3:"

The present writer spent two periods on Ice Island T-3 during 1959 and 1960 and carried out oceanographic observations in the Beaufort Sea. The $\mathrm{T}-3$ drifted from $72.5^{\circ} \mathrm{N}, 130^{\circ} \mathrm{W}$ to $71.9^{\circ} \mathrm{N}, 160.3^{\circ} \mathrm{W}$ between May 1959 and January 1961 . A total of 35 oceanographic stations for subsurface observations were occupied during this period, and 183 bathythermographic observations were made. Taking the drift speed of $\mathrm{T}-3$ into consideration, the subsurface observations were initially planned to be made at about two weeks' intervals. Unfortunately several winch breakdown precluded adherence to this schedule, and a final breakdown of cable drum occurred while occupying Station 10 on September 1959. A replacement winch was put into operation on November 19, 1959 and Sation 11 was obtained.

On the basis of the results of observations made at $\mathrm{T}-3$ the oceanographic features of the northern waters of the American Continent will be discussed. It is regrettable that the available oceanographic data in the central Arctic are very few, despite the fact that the Soviet has sent many parties to the central Arctic. At the time of the preparation of this paper the available Russian data were those from the SP-2 in 1950-1951 and others which have appeared in the Russian" literature.

\section{General Background of the Oceanographical Studies in the Arctic Ocean}

The Arctic ocean has an area of about $14 \times 10^{6} \mathrm{~km}^{2}$ which is approximately the size of the United States. From the viewpoint of oceanography the term "Arctic Basin" which is bounded by the continental slope is frequently used. In a broad sense the Arctic Ocean is the area surrounded by the Eurasian Continent, American Continent, and Greenland. The most part of the Arctic Ocean is covered with pack ice and even in the marginal seas, such as Barents, Kara, Laptev, East Siberia, Chukchi, and Beaufort, sea ice develops in the winter season. The ice concentration of the central Arctic is not less than $8 / 10$ or $9 / 10$ in summer and it attains nearly $10 / 10$ in winter. The Arctic pack ice is consisted of winter ice and perennial ice. The thickness of the ice varies from 2 to 4 meters, in some places where the ice is rafted and hum-

* Abbreviated from "Severnyy Polyus" (North Pole). SP-6 was on an ice island. 
mocked the thickness attains to about 30 meters. The Arctic Ocean covered with the vast ice field plays an important role in the heat budget of the planet earth. Not only from the viewpoint of the heat budget, but for the water and vapor balance study of the Arctic Ocean is badly needed. It is weli known that the drifting stations in the Arctic Ocean were established to attack these problems as a part of the program of the IGY.

The Arctic Ocean is sometimes compared with the Atlantic Mediterranean because its main outlet to the North Atlantic Ocean is the area between Greenland and Svalbard (Spitzbergen). The Greenland Sea is the uniqe place where the major water-mass transfer takes place between the Arctic and the Atlantic ocean. Studies in the Bering Sea, Bering Strait, and the Chukchi Sea have indicated that the water exchange through the Bering Strait is considerably less than that through the Greenland Sea. The water exehange through the channels between the islands in the Canadian Arctic Archipelago is believed to be very small.

The Arctic Ocean has been considered as an extensive and deep depression with a depth of more than 4000 meters since the drift of the Fram led by F. NANSEN (1902) in 1893-1896. The specially designed ship Fram was intentionally allowed to be caught in the ice to the north of the New Siberian Islands from where the ship drifted across a previously unexplored area, finally escaped to the north of Svalbard. Although NANSEN could not reach the geographic North Pole, a great deal of information concerning the Arctic Ocean was collected. The discovery of the character of the wind-driven ocean currents is well know. From the expedition of the Fram the three main water masses in the Arctic Ocean were identified; the Arctic Surface Water, the Atlantic Water, and the Arctic Bottom Water.

In 1925-1928 the Norwegian expedition with the Maud was unable to duplicate the drift of the Fram, being prevented by the adverse ice condition on the Siberian shelf. But this expedition made an outstanding contribution to the hydrography of the Siberian shelf waters, the movement of polar pack, tide and currents, and physical properties of sea ice. In 1931 the submarine Nautilus made a few observations at the north of Svalbard, even though she failed to penetrate into the central part of the Arctic Ocean beneath the pack ice. The Nautilus expedition confirmed the theory of NANSEN which suggested the intrusion of Atlantic Water with high temperature and high salinity under the Arctic Surface Water from the Greenland Sea. In these years, the hypothesis of Harris on the existence of land at the north of Alaska was denied, because the tidal records obtained by the Maud gave no evidence of the existence of land. No land but ice only was seen during the flight of the AmundsenEllsworth-Nobile airship expedition in 1926.

In 1937-1940 the Russian icebreaker Georgy Sedov drifted roughly parallel to the path of the Fram. Soundings and oceanographic observations were made. At the same time a party led by I. D. Papanin landed on the ice floe near the North Pole and drifted to the east of Greenland at an average speed of $9.1 \mathrm{~km} /$ day between May 
21, 1937 and February 19, 1938. This expedition was recently designated "Severnyy Polyus-1." Summarizing the soundings taken during these expeditions, it has been generally accepted that the central part of the Arctic Ocean is an extensive depression. These paths of drift however did not cover the greater part of the Arctic Ocean, extending between $150^{\circ} \mathrm{E}$ and $70^{\circ} \mathrm{W}$.

In the spring of 1946 several landings on ice floes were made by the Russian plane $N-169$, covering several sites in the region so-called "pole of relative inaccessibility." Occupying each site for several days, scientists made oceanographic observations and other geophysical studies. The bottom topography of the Arctic Ocean was still not clear in those years.

Since 1948 the Soviet have continued to send out "High-Latitude Airborne Expeditions"; they have established drift stations in the central Arctic. Making comparison of the temperature of deep layers obtained by the Sedov and N-169, the Russian researchers came to postulate an upheaval of ocean bottom between the meridians of $140^{\circ} \mathrm{E}$ and $175^{\circ} \mathrm{E}$. The bottom temperatures were $-0.78^{\circ} \mathrm{C}$ and $-0.38^{\circ} \mathrm{C}$ at the stations of Sedov and $N-169$ respectively. However this conjecture on the existence of an underwater range was brought to the attention of the present writer by recent Russian literature (TIMOFEYEV 1960). So far as the present writer is aware, the Russian activities since 1939 were first publicized in 1954. It should be worth noting that WORTHINGTON (1953) infered the existence of an underwater range in the central Arctic from the Project Skijump in 1951 and 1952. Subsequent Russian expeditions, particularly in post-war years, were rewarded by the discovery of an underwater range (Lomonosov Range) having a length of about $1800 \mathrm{~km}$. The shallowest depth was 954 meters (GoRdrYEnKo and LAKTIONOV 1960). The Russian drift stations are : SP-2 (1950-1951), SP-3 (1954-1955), SP-4 (1954-1957), SP-5 (1955-1957), SP-6 (1956-1959), SP-7 (1957-1959), SP-8 (1959-1962), SP-9 (1960- ) ), SP-10 (1961- ) ). It was reported that the thickness of SP-6 (ice island) was between 3 and 20 meters.

The bottom configuration of the Arctic Ocean revealed greatly by the Russian is presented in Fig. 1.

Fig. 1 shows the huge underwater range which divides the Arctic Ocean into two depressions; the Nansen Deep in the North Eurasian Basin and the Beaufort Deep in the North Canadian Basin. The Marvin Ridge running in parallel to the Lomonosov Range was revealed by the observations on $\mathrm{T}-3$ and at Drift Station Alpha. In the present paper the terms "Atlantic side" for the North Eurassian Basin and "Pacific side" for the North Canadian Basin will be used.

According to the Russian researchears the maximum depth of 4689 meters was measured in the Beaufort Basin. The Makarov Depression, with depths of over 4000 meters, exists within the area between the Lomonosov Range and the Mendeleyev Ridge and the northern spurs of the Marvin Ridge. The Litke Depression lies in the Atlantic side with a maximum depth of 5449 meters at $82^{\circ} 24^{\prime} \mathrm{N}$ and $19^{\circ} 31^{\prime} \mathrm{E}$. During 1955 and 1958 Russian ships sounded the area between Greenland and Svalbard. The ex- 


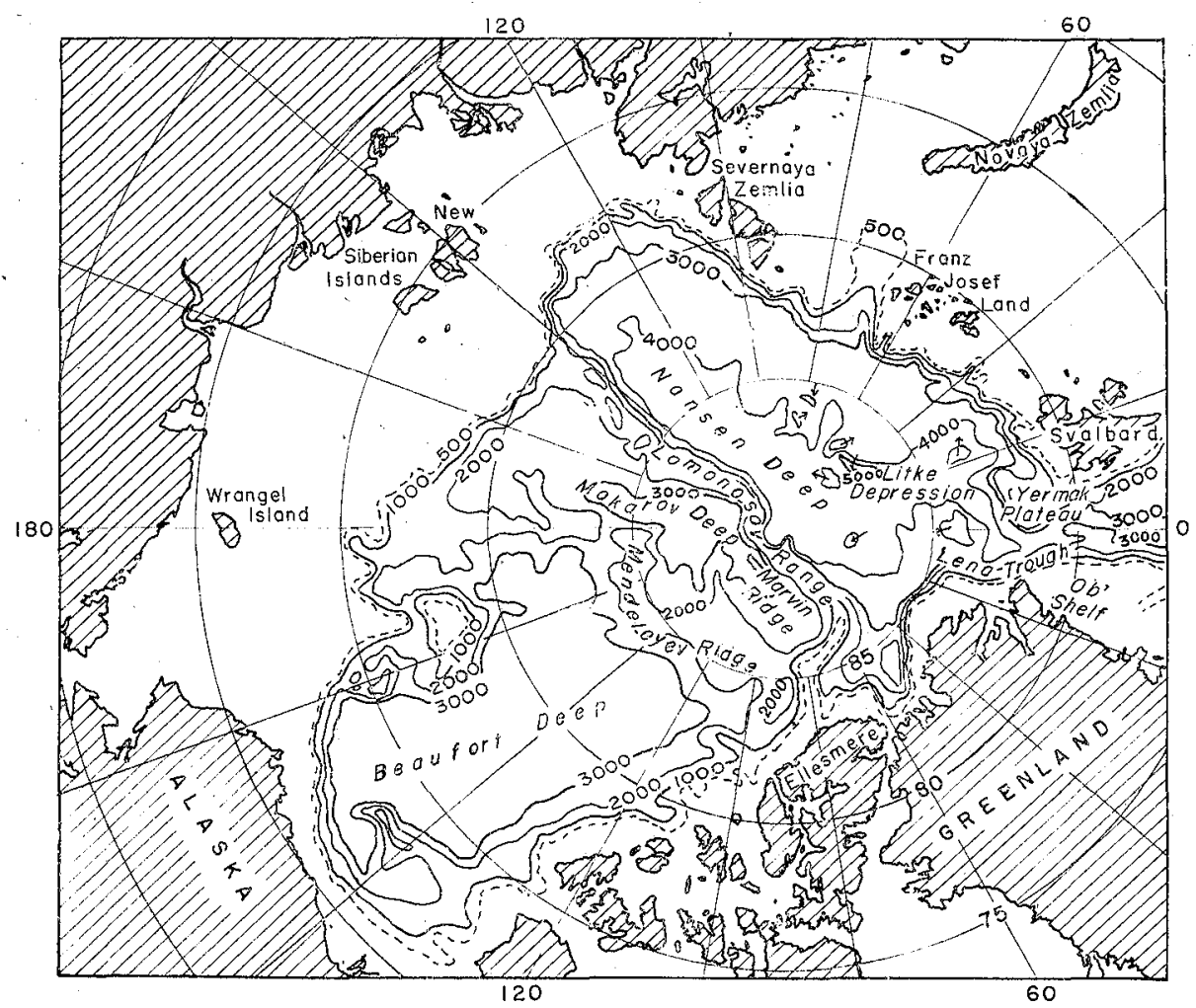

Fig. 1. Bathymetric chart of the Arctic Ocean.

istence of the continuous Nansen Sill was denied. The Nansen Sill, foremerly believed to be about 1300-1400 meters deep, is cut through by a deep-water trough (the Lena Trough) with depths of 3100-3400 meters in the northern part and 3500-3900 meters in the southern part (LAKTIONOV 1959). However the depth-soundings in the Arctic Ocean are still few in number, and it is certain that many minor bottom configuration, such as submerged valleys, canyons, troughs, rises, and sea-mounts, will be discovered by future observations. As an example of recent activity in this line, it will be noted that a minimum depth of $1462 \mathrm{~m}$ was recorded at $85^{\circ} 03^{\prime} \mathrm{N}, 171^{\circ} 00^{\prime} \mathrm{W}$ on the Mendeleyev Ridge by the soundings taken from Drift Station Alpha.

In contrast to the oceanographic exploration in the Atlantic side, the investigations in the Pacific side have made slow progress. In 1951 and 1952 oceanographic observations under Project Skijump were made at various points on the Pacific side by the use of aviation. As mentioned before, analyzing the temperatures in deep layers, WORTHINGTON (1953) postulated the existence of a ridge with a sill depth of less than 2300 meters. In the mean time SP-2 (1950-1951) drifted in the western part of the Pacific side along the meridian of about $175^{\circ} \mathrm{W}$, between $76^{\circ} \mathrm{N}$ and $81^{\circ} \mathrm{N}$. This station (abandoned) was found in April 1954 to the north of Wrangel Island $\left(75^{\circ} 04^{\prime} \mathrm{N}, 172^{\circ}\right.$ 
$20^{\circ}$ ) and it was conjectured that the SP-2 had drifted clockwisely in the Pacific side.

In the post-war years, shipboard observations have been made in the coastal waters along the American Continent. Some ships thus penetrated into the pack ice as far as to $75^{\circ} \mathrm{N}$ and also the observations in the waters of the Canadian Arctic Archipelago became active in recent years. The following names of the Canadian and American vessels may be cited: Atka, Burton Island, Cancolin, Cedarwood, Eastwind, Eldorado, Labrador, Nereus, and Northwind.

The drifting stations established by the United States provide useful means for oceanographic research of the Pacific side of the Arctic Ocean. The paths of drift of ships and stations on ice floes suggest the scheme of the surface circulation of the Arctic Ocean. The subsurface observations made at those stations and ships reveal the physical, chemical, biological, and geological features of the Arctic Ocean. In Fig. 2 the paths of drifts are represented; in it the drift of ice islands in the Pacific

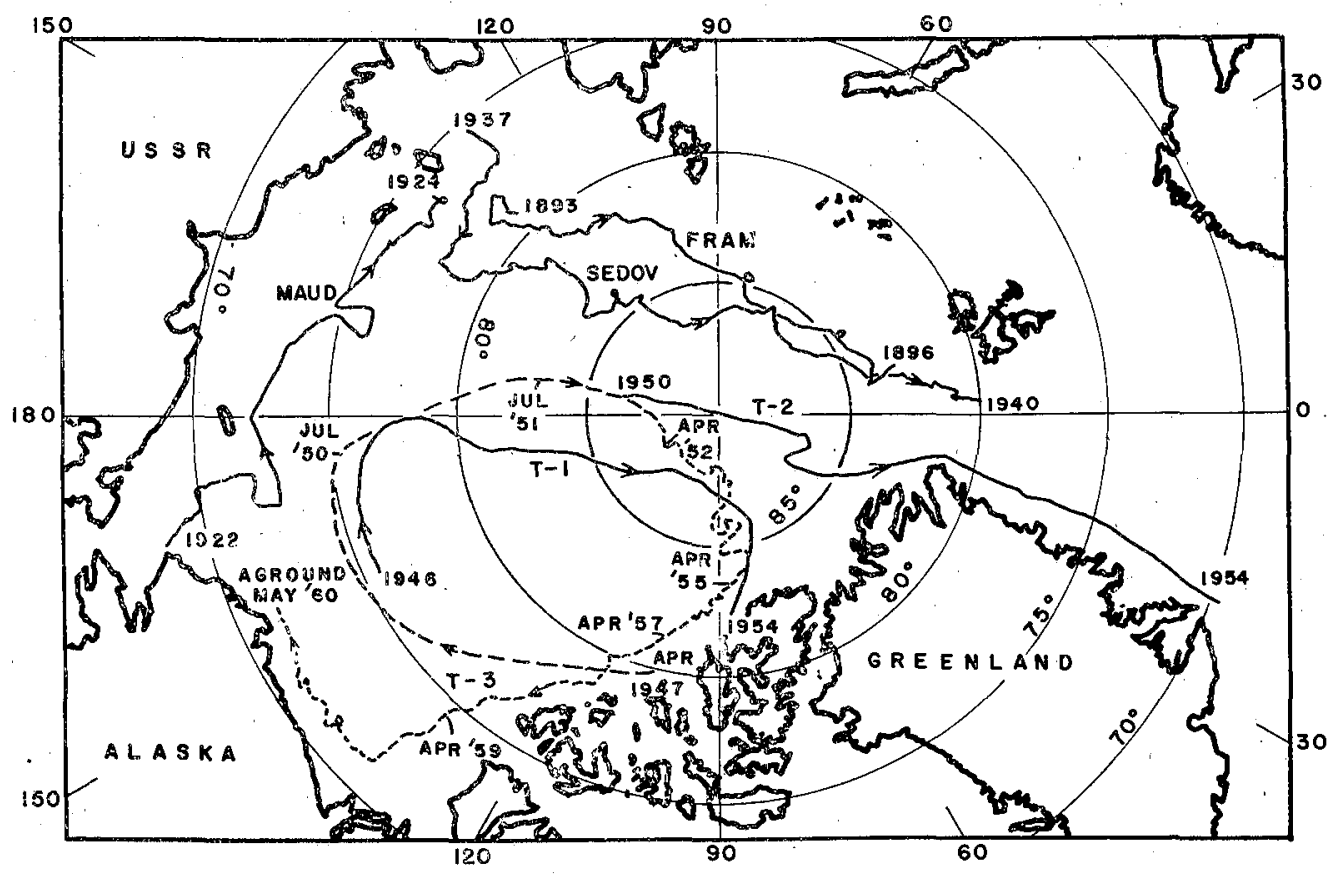

Fig. 2. Drift paths of ships and ice islands.

side is emphasized. A very large anticyclonic vortex is to be noted from Fig. 2. More detailed information on the paths of drift stations and icebound ships may be obtained in many publications; e.g., in the "Oceanographic Atlas of the Polar Seas, Part II, Arctic" (U.S. NAYY HYDRGGRAPHIC OFFICE 1958). 


\section{General Accout of the Ice Islands}

On August 14, 1946 an enormous mass of floating ice among the polar pack was discovered less than 300 miles* north of Point Barrow, Alaska by an aircraft of the U. S. Air Force. This was originally recognized by means of the radar in the aircraft, hence designated "Target $\mathrm{X}$ " or "T-1" in later dates. In the succeeding years the movement of $T-1$ has been traced by radar and visual observation. The $T-1$ had an area of about $600 \mathrm{~km}^{2}$ and its surface was even with a broad undulation. Many conjectures have been made as to the thickness, the location of calving, growth mechanism, surface topography, inner structure and so forth. An extensive search for other ice islands was commenced in May 1950 and led to the discovery of $T-2$ and $T-3$ in the Pacific side of the Arctic Ocean. Also a number of small islands were found among the channels in the Canadian Archipelago. The $T-2$ with an area of $800 \mathrm{~km}^{2}$, the largest one ever found, was located at $84^{\circ} 40^{\prime} \mathrm{N}, 167^{\circ} 00^{\prime} \mathrm{E}$ on July $19,1950$.

Ice Island $\mathrm{T}-3$ was first sighted at $75^{\circ} 24^{\prime} \mathrm{N}, 173^{\circ} 00^{\prime} \mathrm{E}$ on July. 29,1950 . This island was later identified as having already been photographed on April 27, 1947 at $79^{\circ} 50^{\prime} \mathrm{N}, 104^{\circ} 00^{\prime} \mathrm{W}, 30$ miles north of Isachsen Peninsula in Ellef Ringes Island. The three Ts had an enormously large mass different from the ordinary polar floes and surface of the islands was surprisingly smooth at the time of discovery. The examination of past publications led to the opinion that these ice islands were very likely the so-called "disappeared islands in the Arctic Ocean." (KoENig et al, 1952, KusunokI $1955 \mathrm{a}, 1960$ b).

In the meantime, the Russians reported that the existence of ice islands was first discovered by the pilots of High-Latitude Airborne Expeditions and ice reconnaissance flights. They designated those islands as the Kotov (discovered in March 1946), the Mazuruk (1948), and the Perov (1950) after the names of the pilots. So far as the present writer is aware, the identity between those islands and the three Ts is ambiguous. Setting aside the problems of priority of discovery, subsequent observations of the position of the ice islands have enabled one to estimate the surface circulation in the Arctic Ocean, particularly of the Pacific side. The clockwise path of drift of $\mathrm{T}-3$ illustrated in Fig. 2 indicates that it has taken about ten years to complete the circular motion in the Pacific side. The average speed of drift was $0.8 \mathrm{~km} /$ day.

The scientific work at T-3 was initiated in April 1952 when a small party led by J. O. Fletcher made the first landing to establish the scientific station. Thereafter the island has been occasionally called "Fletcher's Ice Island" or "Fletcher's Ice Island T-3". The scientific observations at ice islands can be divided into two catagories. In the first category, observations on meteorology, oceanography, gravity, earth magnetism, and aeronomy are included. For the sake of these observations the ice island serves as a convenient means, just like a research ship. The second category includes

* Nautical miles are used in the present paper. $1 \mathrm{n}$. mile $=1852 \mathrm{~m}$. 


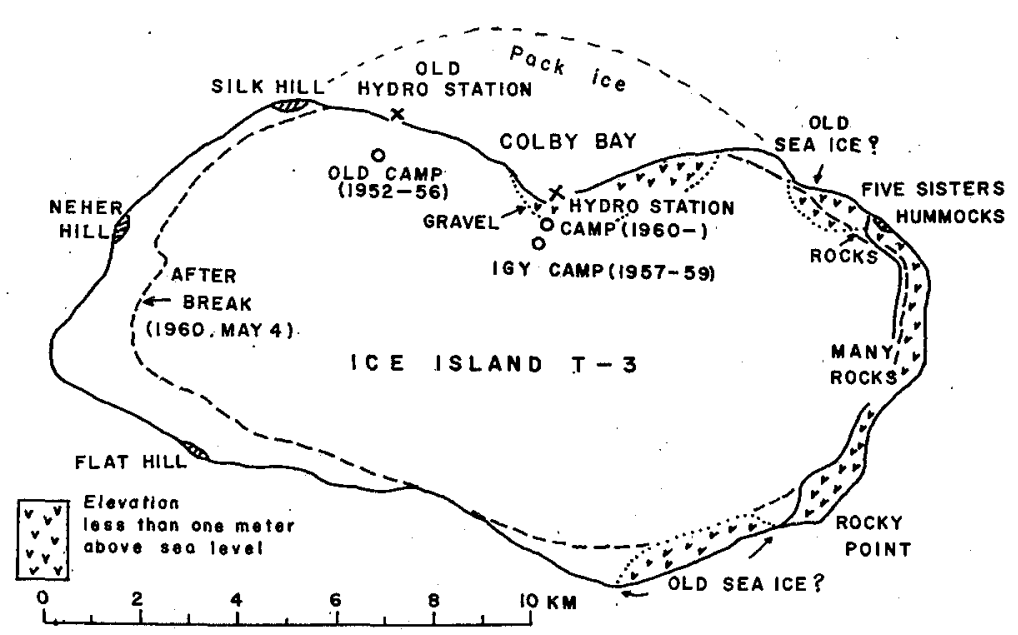

Fig. 3. Map of Ice Island $T-3$.

studies of the ice island itself: its surface and subsurface morphology, ice structure, fauna and flora, inorganic deposits, and other related subjects.

In Fig. 3 a sketch map of Ice Island $T-3$ is illustrated. The $T-3$ has a size of $7 \times 15 \mathrm{~km}$ with a thickness of 50 meters on the average. Since the occupation of T-3 in 1952 there has been no apparent change in its shape which was under the influence of ice pressures by the surrounding. Arctic pack. In the early part of May 1960 when it was in proximity to Point Barrow, the $\mathrm{T}-3$ was grounded in shallow water and a part of it was broken off but the main part was left without any remarkable deformation or cracking. It was reported that $T-3$ was refloated in the spring of 1962.

A very broad trough and ridge system develops on the surface of $\mathrm{T}-3$ and a drainage system also develops in troughs and lower places in the summer season. To traverse the surface in the summer season is fairly difficult. In the winter the rugged surface is smoothed out by the drifted snow. The average surface elevation above the sea level was 7 meters when CRARY and others (1952) made the survey in 1952. As shown in Fig. 3, in some places the surface elevation is nearly at sea level. Many rocks and much gravel were found at the periphery of the island. In the summer season the surface of $\mathrm{T}-3$ is covered with fine mud deposited on the ice surface and in the subsurface layers. The available rock specimens from $T-3$ and Ellesmere Island point to the possible origin of $\mathrm{T}-3$ as the northern shore of Ellesmere Island where the Ellesmere Ice Shelf develops. Fauna and flora specimens collected on the $\mathrm{T}-3$ were used to locate the birthplace and their radiocarbon dating indicated that the $T-3$ and Ellesmere Ice Shelf were formed definitely later than the end of the Wisconsin ice age some 11,000 years ago. It was reported that the growth of the ice island started about 5,500 years ago, that the last accumulation period began about 1,600 years ago and lasted for about 400 years ago, and that the present ablation period then started. 
The date of calving of $\mathrm{T}-3$ from Ellesmere area was estimated by examining the plant specimens and mosses found on both $\mathrm{T}-3$ and Ellesmere. It was deduced that the T-3 left from the shore of Ellesmere Island at a time not earlier than 1935. These conjectures are based upon the observations at T-3 during 1952 and 1955 and upon surveys at the northern shore of Ellesmere Island, in paralell with laboratory studies. During these years the station at T-3 was evacuated in May 1954 when the island drifted into the proximity of the land weather stations of the Canadian Arctic. A party re-occupied T-3 during the period April to September in 1955. CRARY (1956, 1958, 1960) sumarized his studies on T-3 and Ellesmere region.

Prior to the period of the IGY the oceanographic observations on $T-3$ had been carried out at the "Old Hydro-Station" near the "Old Camp". An ice-hole opened in the perennial sea ice attached to the T-3 was used for the oceanographic work. In Colby Bay area, between Silk Hill and Five Sisters Hummocks, many-wintered polar ice with a thickness of about 5 meters existed. Between 1952 and 1955 eleven stations were taken, ten in 1952-1953 and one in 1955. Biological investigations and bottom sampling were made at Old Hydro-Station. Details of the facilities of this station were described by MOHR (1959). The data of temperature and salinity during this period were presented by WORTHINGTON (1959). However, salinity values for Sts. 1-4 are not given because of the difficulty in shipping of water samples under severe Arctic environment and long transportation route.

As already mentioned, the United States established two drift stations for executing the IGY program in the Pacific side of the Arctic Ocean. The station Alpha on the ice floe was maintained between the early spring of 1957 and December 1958 when the station was evacuated due to the ice-breakup. The second one on the pack ice, designated Charlie, was set up at about 300 miles north of Point Barrow. This station was active from June 1959 to January 1960 when inevitably evacuated because of icebreakup. The icebreaker Burton Island was successful in establishing the third one, Arlis $-1^{*}$, on the pack ice in the Beaufort Sea on September 12, 1960, and this station was abandoned in the late of March 1961. A new ice island bearing rocks that are heaped about 15 meters high in places was found in late may, 1961 (Arlis-2). The. new ice island was roughly 150 miles north and slightly east of point Barrow at the time of discovery. It was reported that the new ice island is fifty feet thick, two miles wide and three miles long.

Ice Island T-3 (designated Drift Station Bravo in the IGY) drifted from $82^{\circ} 51^{\prime} \mathrm{N}$, $96^{\circ} 10^{\prime} \mathrm{W}$ on May 20,1957 (oceanographic station No. 12) to $80^{\circ} 02^{\prime} \mathrm{N}, 115^{\circ} 50^{\prime} \mathrm{W}$ on May 15, 1958 (station No. 17) during the IGY. Those oceanographic stations were numbered in a series of observations dating back to 1952 . The results of observations were presented by FARLOW III (1958) and APOLLONIO (1958) who did the biological work. Between May 26, 1958 and September 28, 1958 a total of 21 stations were

* Arctic Research Laboratory Ice Station (Arlis). 
taken by COLLIN (1958), a representative from the Canadian Fisheries Research Board.

The oceanographic work in 1959-1960 has largely in the nature of continuation from the program in the IGY. During this period a new hydro-station was established on the perennial sea ice in Colby Bay (see Fig. 3). During the summer of 1959 the present writer with the assistance of J. Muguruma, who conducted the later winter observations, carried out the observations. The preliminary results have been reported by KuSUNOKI (1960 a) and MUGURUMA (1961) for summer and winter observations respectively. In the early part of May 1961 the $\mathrm{T}-3$ grounded at about $72^{\circ} \mathrm{N}, 160^{\circ} \mathrm{W}$ and has remained in approximately the same position until the spring of 1962 . The observations between May and September 1960 were made by Muguruma and K. Higuchi. A summarized report on the observations during 1959-1960 is presented by KuSUNOKI et al. (1962).

It is to be noted that many reports on the results of observations accomplished at $\mathrm{T}-3$ during the period of 1952-1955 under various scientific disciplines are presently in course of publication (BUSHNELL 1959).

\section{Instrumental and Observational Aspects of the Work at Ice Island $T-3$ in 1959-1960}

In May of 1959 a new hydro-station was established on the old pack ice in Colby Bay and a laboratory in the main camp was equipped. At this itme the pack ice with a width of 1 to 2 miles had been attached to the island for at least several years. An ice-hole with a diameter of about 2 meters was opened through the pack ice of 5.5 meters thick with the aid of explosives. In the vicinity of the hydro-station there were erected two shelters for seismic work and underwater acoustics. The location of the hydro-station was selected on a flat-topped broad ice mound in the uneven old sea ice.

A two-section Jamesway shelter was constructed beside the ice-hole to provide a place for storing provisions and working space. A gasoline engine driven winch was set up between the Jamesway shelter and the ice-hole. An A-frame equipped with a meter wheel was set on timbers arranged in parallel crosses over the ice-hole. During the summer of 1959 troubles in the winch were experienced and on September 9 the cable drum was broken during the occupation of St. 10. A new winch was supplied on October 29 and this was installed within the shelter which had been moved onto the lower ice surface of the frozen melt water pool around the ice-hole. The transfer of the Jamesway shelter onto the lower ice surface was necessitated by the heavy ice ablation during the summer.

Until the early part of June the air temperatures were usually below $0^{\circ} \mathrm{C}$, so that an ice rind having a thickness of about $3 \mathrm{~cm}$ formed on the surface of water in the ice-hole in every day. Between June to September, the ablation of ice, both on the island and the sea ice, took place intensively. The average ablation loss over the island was estimated as $160 \mathrm{~cm}$ in ice thickness. Even on the surface of pack ice with high 
albedo the ablation was very active. The explosive dust around the ice-hole accelerated the melting of ice there.

Owing to the sub-zero temperatures in the middle layer of pack ice an accretion of ice took place on the wall-surface of the ice-hole. The diameter of the hole decreased to about $30 \mathrm{~cm}$ from May 28 to July 2. The accreted ice was dynamited, but this was not effective, and finally the melt water having a temperature of slightly above $0^{\circ} \mathrm{C}$. was channeled into the ice-hole. This water melted the newly-formed ice and the shape of ice-hole in the final stage was truncated cone. This shape was very favorable for the oceanographic cast when the cable was inclined by currents. The thickness of fresh water filled in the ice-hole was less than 6 meters even in the period of maximum discharge.

In the middle of August the formation of anchor ice in the ice-hole was frequently observed. It was believed that the anchor ice was formed at the interface between the warm fresh water and underlying saline water with low temperatures of nearly freezing point. A great amount of anchor ice was scooped out almost every day. The ice ablation ceased in the early part of September; the discharges from the streams on T-3 decreased and the melt water pools on the pack ice began to solid.

During the ablation season a heavy tent sheet was spread over the ice-hole to cut off the intensive solar radiation. The parachute cloths used for air-drop were skirted around the Jamesway shelter. However, at the end of the season, an ice rampart about 2 meters high remained in the shaded area around the ice-hole and the shelter was left on an ice mound of barely 2 meters height. The ablation was very pronounced at the main camp area which was much contaminated because of oil and dust particles. This necessitated the transfer of the main camp to a new site in the spring of 1960 (see Fig. 3).

In the winter of 1959-1960 the ice-hole was thermally insulated by a wooden frame and heavy cloths. The ice rampart which remained around the ice-hole was useful in the construction of a covered frame. An oil stove set inside the hut was enough to keep open the ice-hole even at a low temperature of $-40^{\circ} \mathrm{C}$. During this period the diameter of the hole was kept about one meter. Due to the damage to the cable, some of the casts were restricted to approximately 1,000 meters depths.

On May 4, 1960 the $\mathrm{T}-3$ ran aground at the position of $71^{\circ} 53^{\prime} \mathrm{N}, 159^{\circ} 37^{\prime} \mathrm{W}$ and has remained in approximately the same position $\left(71^{\circ} 52^{\prime} \mathrm{N}, 160^{\circ} 20^{\prime} \mathrm{W}\right)$ until 1962 , with the exception of drifts which occurred in the middle of May and July 1960. As the shelter had been set up on a low elevation, flooding on the ice floor around the hole took place in the middle of May. At a site about 15 meters from the edge of the island a new ice-hole was opened at the end of May. The new ice-hole; one meter square, was opened with chain-saw and explosives through the ice with a thickness of 5.2 meters. On this occasion, a four-section Jamesway shelter equipped with a winch was placed on heavy wooden skids and pulled over the hole. One floor panel was removed for the cast. In the middle of July, heavy ablation occurred around the 
shelter, but a small hand winch sufficed for carrying on the observation, rather than operating the heavy gasoline-driven winch inside the shelter set on the ice mound. At the end of August, soon after the third grounding of the island, the program was suspended due to the breakup of the pack ice in Colby Bay and the shelter was removed onto the island. Fortunately the pack ice around the ice-hole was not broken off, so that the observation was made by means of the hand winch through the uncovered ice-hole.

In 1959 electric power was supplied from an electric generator driven by a gasoline engine which was set up near the shelter. In the spring of 1960 the main camp was moved to a new site and electric transmission lines were installed to the shelters in Colby Bay area.

A description will be given on the instruments and the method of chemical analysis.

Water sampling bottles: Six Nansen type water sampling bottles each equipped with a two-thermometer frame were used at each cast. Additional Nansen bottles were found at the main camp, but due to the limitation of thermometers, only six were lowered at each cast. Bottles with protected-unprotected pairs of thermometers were placed between bottles with two-protected thermometers at each lowering. This was a necessary procedure to determine the depth of the observation layers.

Reversing thermometers: All protected thermometers were graded for low temperature range, viz., -2 to $8^{\circ} \mathrm{C}$ or -2 to $10^{\circ} \mathrm{C}$. The values of the pressure coefficients of unprotected thermometers were calibrated at depths of 500,1000, 1500, and 2000 meters when there was no perceptible inclination of sounding wire. A calibration of the meter wheel was also carried out by paying out the wire less than 20 meters. A conversion factor of 0.982 was finally adopted for readings of the meter wheel. On several occasions a separation of the mercury in the capillaries of the reversing thermometers resulted when the thermometers were lowered into the cold water.

Bathythermograph $(B T)$ : A bathythermograph was used for the observation of temperature down to about 250 meters. At each cast of the BT the temperature at 15 meters, on occasionally at 0,10 , or 15.5 meters, was read by means of reversing thermometers attached to the Nansen bottle. The surface temperatures exhibited a wide variation under the influence of summer air temperatures, solar radiation, and the local effect of the ice hole. For this reason, the temperature at 15 meters was read to correct the $\mathrm{BT}$ records. The $\mathrm{BT}$ casts were usually made on alternate days, and at the beginning and end of each subsurface serial observation. Malfunctioning was experienced during the winter of 1959-1960. The results of BT observations were presented in the appendix of the report of KUSUNOKI et al. (1962).

Water preserving bottles: Ordinary glass bottles with rubber stoppers were used for the samples for chlorinity titration. During the summer of 1959 a sufficicent number of glass bottles for complete oxygen analysis was not available; therefore, 
sampling depths were predetermined to cover the standard depths only. Polyethylene bottles, $150 \mathrm{ml}$ in content, were used for silicate-Si samples. Since the analysis was performed at the chemical laboratory at $\mathrm{T}-3$, problems such as freezing of water, evaporation, or breaking of bottles, frequently experienced in previous years during shipment, were eliminated.

\section{Method of chemical analysis}

Chlorinity: Knudsen's method modified by the use of uranin as an indicator (Fajans-Miyake's method) was adopted. All the samples, with the exception of brackish surface waters, were titrated independently by the persons until the results were in agreement with an error less than 0.01\%. In the winter of 1959-1960 titrations were performed by one person three or more times, if necessary, to achieve the required precision." The normality of $\mathrm{AgNO}_{3}$ solution was determined by the use of "Eau de mer normale" prepared by the Hydrographical Laboratory in Copenhagen. Fresh and brackish water less than $17 \%$ in chlorinity was titrated by Mohr's method.

Dissolved oxygen content: Dissolved oxygen content was measured by Winkler's method using $\mathrm{KIO}_{3}$ as the standard. The saturation percentage was calculated by the use of Fox's formula. Since the content of the oxygen bottle was $250 \mathrm{ml}$, two or more titrations were possible and results were averaged.

Silicate-Si content: The content of silicate-Si was colorimetrically determined by the method of Diénert and Wandenbulke. A Klett-Sommerson colorimeter was used for this procedure. The analyses were performed within a few hours after sampling, in order that the concentration of Si might not undergo any appreciable change due to biological activity. Since the water temperatures of the Arctic Ocean are very low, errors due to the preservation of sampled waters may be very small.

The data of the subsurface observations have been interpolated to provide standard depths and presented in the appendix of the report of KusuNOKI et al. (1962).

\section{Distribution of Temperature}

The distribution of temperature in the Arctic Ocean depends upon a number of factors, foremost among which are the amount of radiation income, the ocean currents, and the ice condition. The intensive solar radiation in the summer, almost 24 hours of daytime, accelerate the melting of pack ice and warm up the surface water. The temperature of the surface water, particularly of the open waters, sometimes exceeds $0^{\circ} \mathrm{C}$. At this time, the river discharges from the Eurasian and North American continents contribute to dilute the surface salinity and to increase the temperature. It is known that the warm Atlantic Water enters into the Arctic Basin beneath the cold surface water. The inflow of Pacific water through the Bering Strait exerts a subsidiary effect upon the temperature distribution of the Arctic Ocean, particulary of the Beaufort and Chukchi Seas. The sea ice in the Arctic Ocean plays an important role in the vertical and horizontal distribution of water temperature. In general, very 


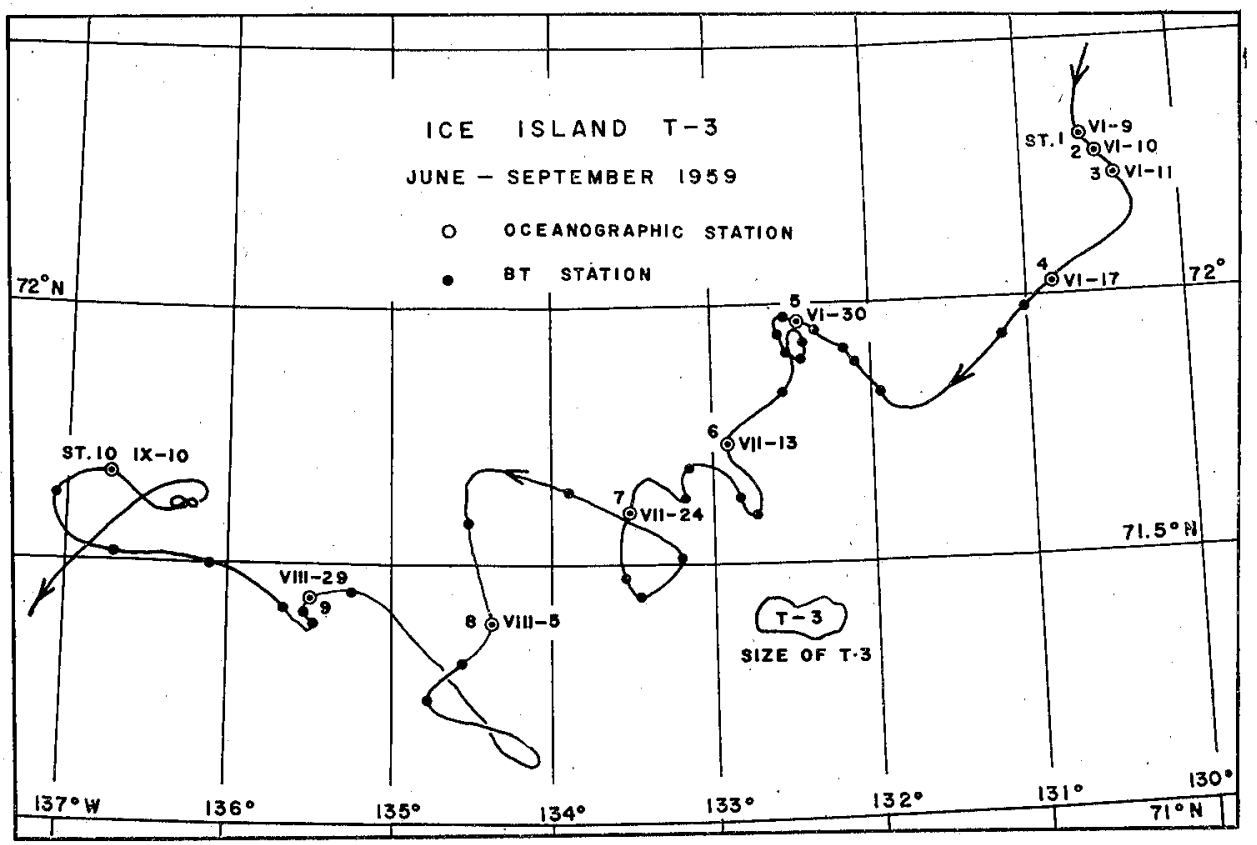

Fig. 4 a. Fath of Ice Island $T-3$ and positions of stations, June-September 1959.

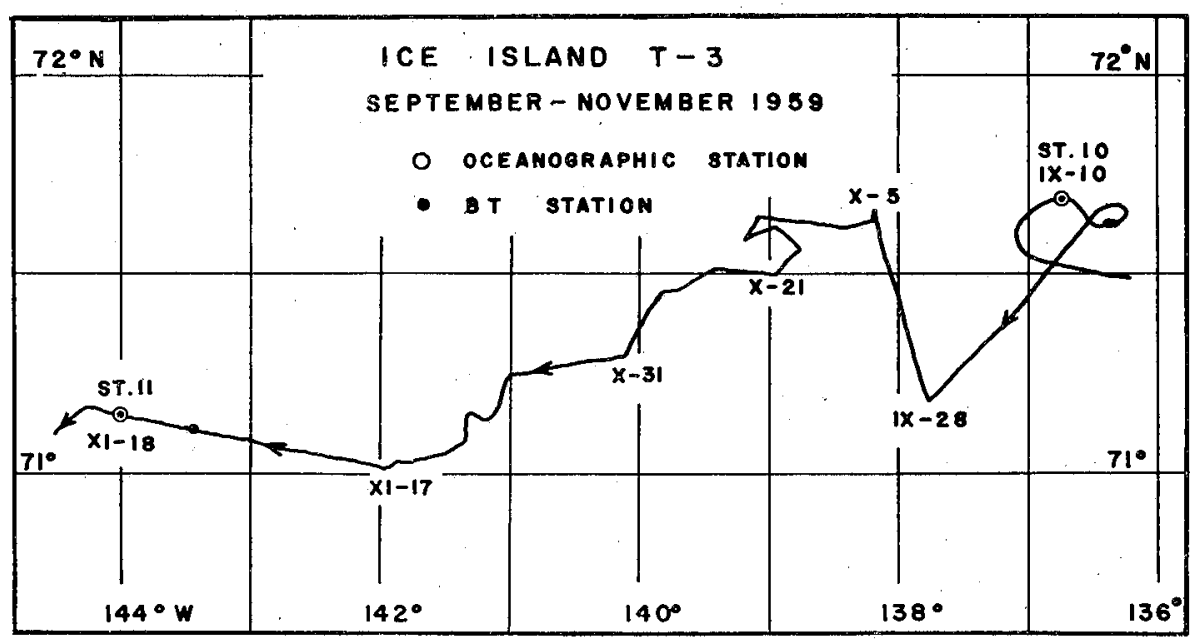

Fig. 4 b. Path of Ice Island $T-3$ and positions of stations, September-November 1959. 


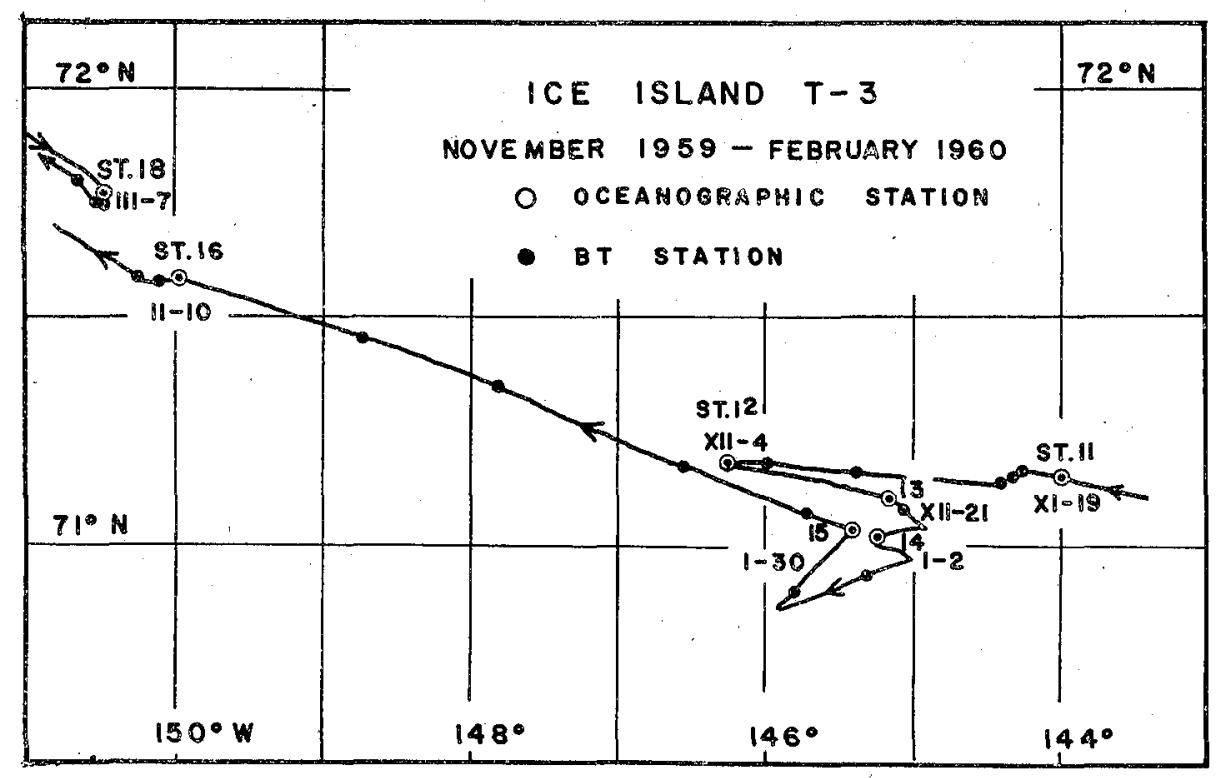

Fig. 4 c. Path of Ice Island T-3 and positions of stations, November 1959 .February 1960.

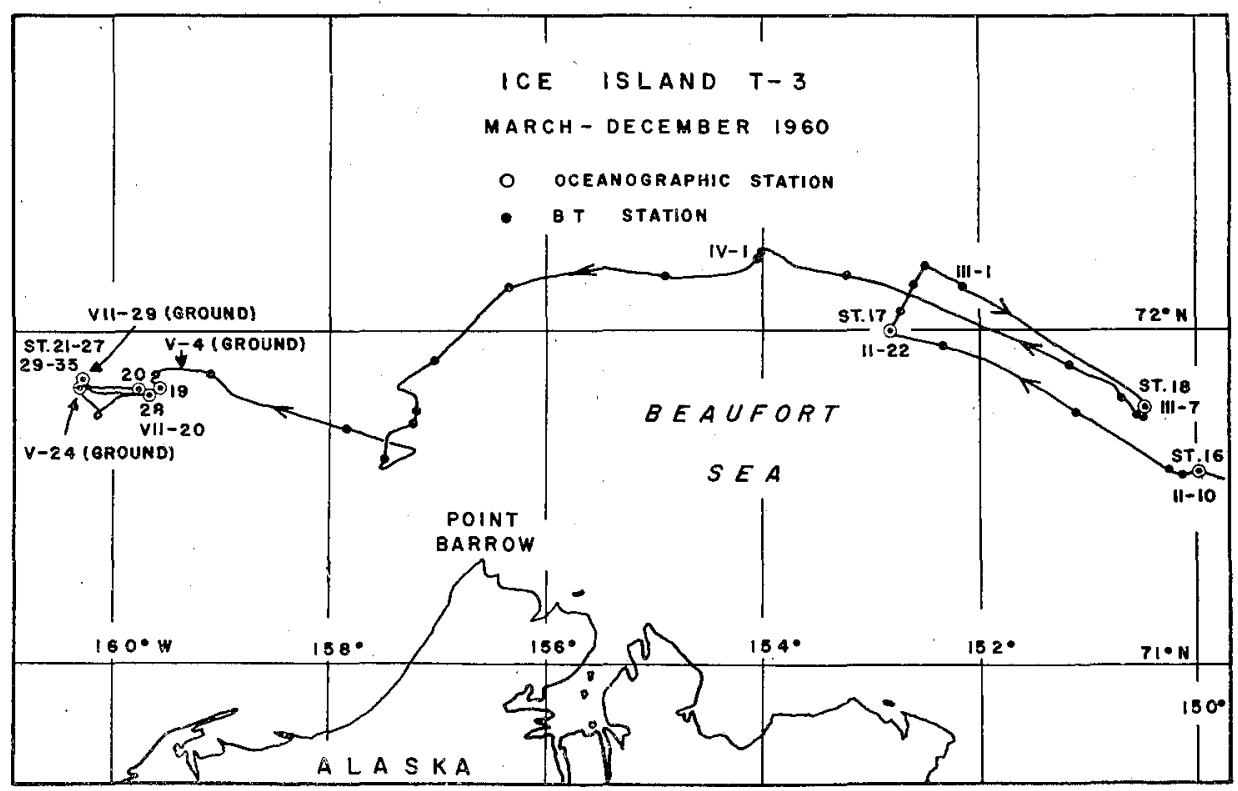

Fig. 4d. Path of Ice Island T-3 and positions of stations, February-December 1960. 
stable stratification is observed at the top layer in the summer and this stratification is eliminated by the winter vertical convection due to the formation of ice.

In order to discuss the distribution of temperature in the Arctic Ocean, particularly of the Pacific side, the data taken at T-3 during 1959-1960 will be analyzed.

The oceanographic observation stations occupied at $\mathrm{T}-3$ cover the area of the southern Beaufort Sea between $70.8-72.5^{\circ} \mathrm{N}$ and $130-160.3^{\circ} \mathrm{W}$. The locations of the oceanographic and BT stations are illustrated in Fig. 4 a, b, c, and d. These figures also indicate the path of the drift between June 1959 and September 1960. As mentioned before, the $\mathrm{T}-3$ remained at $71^{\circ} 52^{\prime} \mathrm{N}, 160^{\circ} 20^{\prime} \mathrm{W}$ between July 29,1960 and the spring of 1962. Before the grounding 18 stations were occupied during the westward drift in the southern Beaufort Sea. In the vicinity of the grounded position, Stations 19 through 35 were occupied.

In order to exhibit the general information concerning the vertical distribution of temperature, plots of the temperature data form all stations taken at $\mathrm{T}-3$ are given in Fig. 5, in which the data from Sts. 19 to 35 on the shallow shelf are shown in open circles.

With the exception of the summer values at the surface, the temperatures at the surface layers of less than 50 meters were very low. In some cases, especially at Sts. 19 to 35 , the supercooling of water to the extents of $0.05^{\circ} \mathrm{C}$ was observed in the upper layer. Similar phenomena have been observed at the estuaries on the Okhotsk sea coast of Hokkaido and a quantitative discussion on the occurrence of supercooling was given by FukuTOMI et al. (1950).

A minor maximum, more pronounced in winter stations, was observed at each station at an average depth of 75 meters. The maximum value of $-1.08^{\circ} \mathrm{C}$ was observed at St. 17 taken on February 22,1960 at about $72^{\circ} \mathrm{N}, 153^{\circ} \mathrm{W}$. The second minimum of $-1.46^{\circ} \mathrm{C}$ in average at 150 meters was recorded. A very remarkable thermocline existed throughout all stations between 200 and 300 meters. Below this level the Atlantic Water, having positive temperatures, was always found. The average upper and lower $0^{\circ} \mathrm{C}$-isotherms were at 280 and 850 meters. The average maximum temperature of the core of the Atlantic Water was $0.42^{\circ} \mathrm{C}$ at 450 meters. At depths below 900 meters the temperature decreased gradually and a temperature of $-0.43^{\circ} \mathrm{C}$ was recorded at about 2000 meters. Due to the limitation of the cable the present observations did not cover the temperature profile down to the bottom at deep stations. However the data from other sources, e.g., Project Skijump, SP-2 and the T-3 in previous years, indicate that the increase in temperature toward the bottom is at a rate of adiabatic heating. It seemed that the average minimum temperature of $-0.43^{\circ} \mathrm{C}$ occurred at a level slightly below 2000 meters in the deep layer.

The vertical distribution of temperature at each station will be recognized from Figs. $6 \mathrm{a}, \mathrm{b}, \mathrm{c}, \mathrm{d}$ and $\mathrm{e}$, in which the results of observations on chlorinity, oxygen content, silicate-Si and computed density in sigma-t are included. 


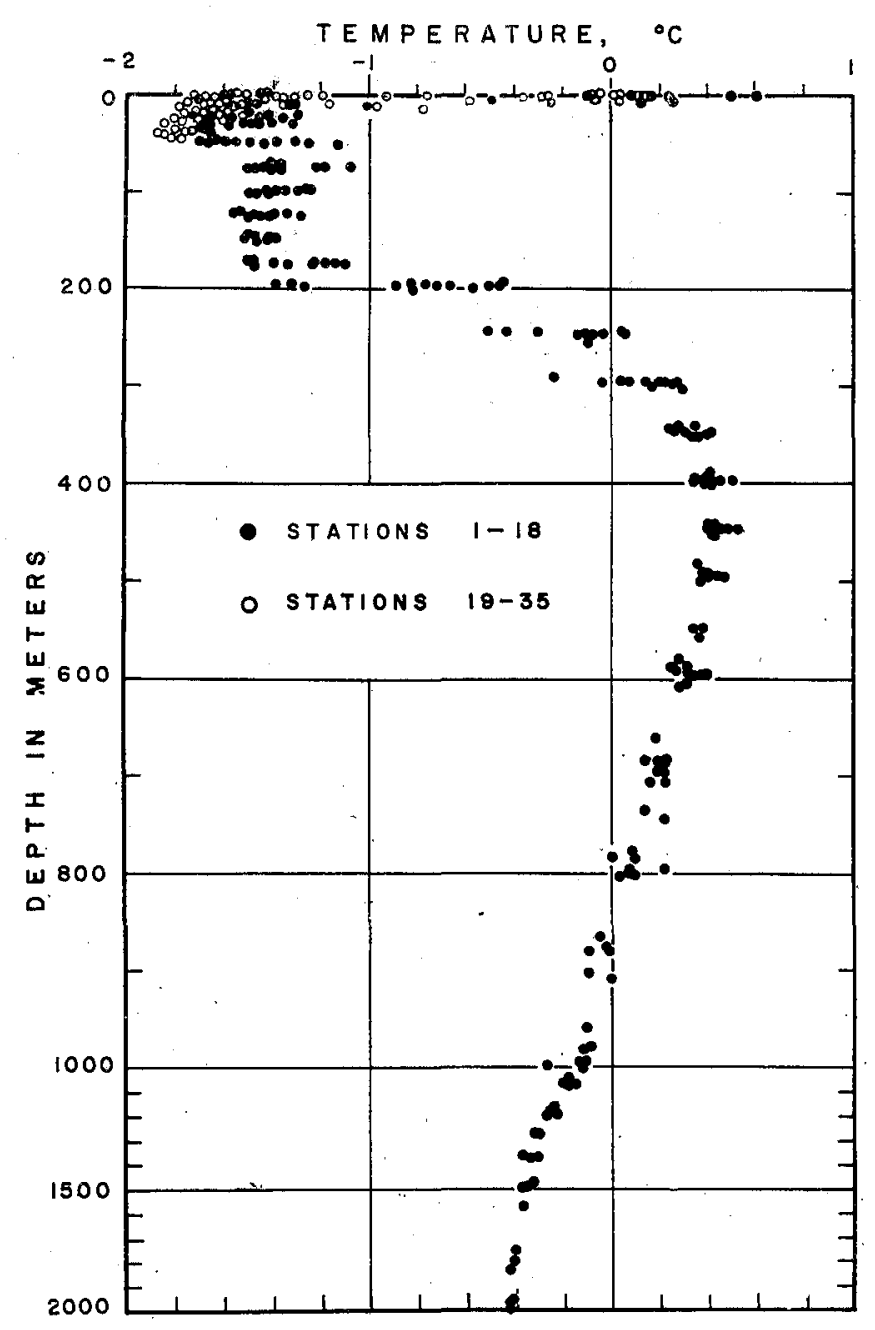

Fig. 5. Vertical distribution of temperatures observed at T-3 in 1959-1960.

Fig. 6 a represents the vertical distribution of temperature in the middle of summer, June 30,1959 . The heating of the surface layer is clearly notable. It should also be pointed out that a minor maximum in temperature was recognized at about 100 meters. As stated previously, this minor maximum was prominently observed at 75 meters depth of St. 17 (Fig. 6 c), while less pronounced at St. 11 (Fig. 6 b). The temperature in the deeper layers below thermocline at about 200 meters did not show great change from one locality to another. Figs. $6 \mathrm{~d}$ and $6 \mathrm{e}$ are shown as examples of the vertical distribution of temperature and other oceanographical elements in shallow water on the shelf. The former was occupied in the middle of May when the winter vertical convection reached down to the bottom. A very homogeneous 


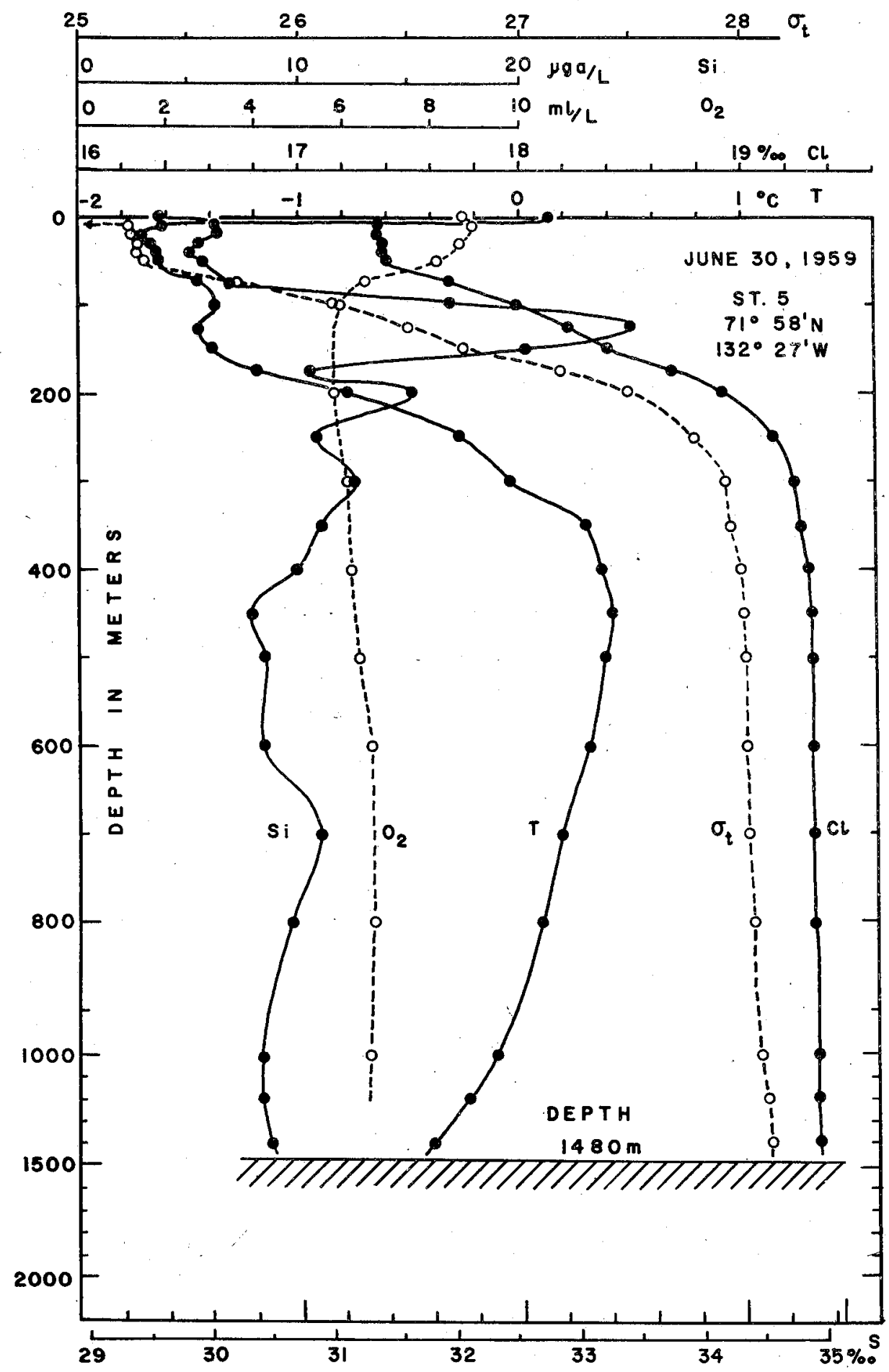

Fig. 6a. Vertical distribution of temperature, density, and chemical elements at Station 5, June 30, 1959. 


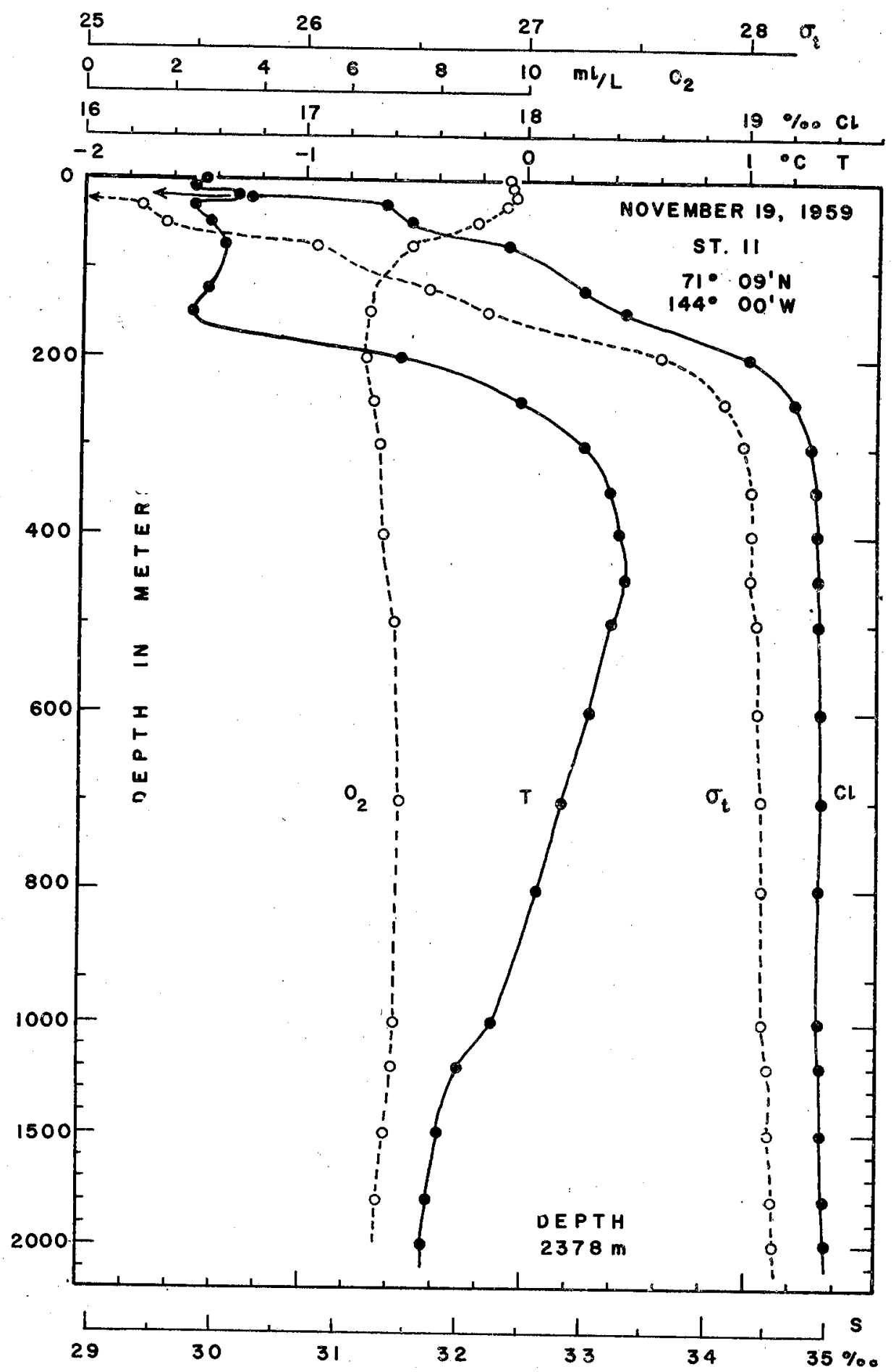

Fig. $6 \mathrm{~b}$. Vertical distribution of temperature, density, and chemical elements at Station 11, November 19, 1959. 


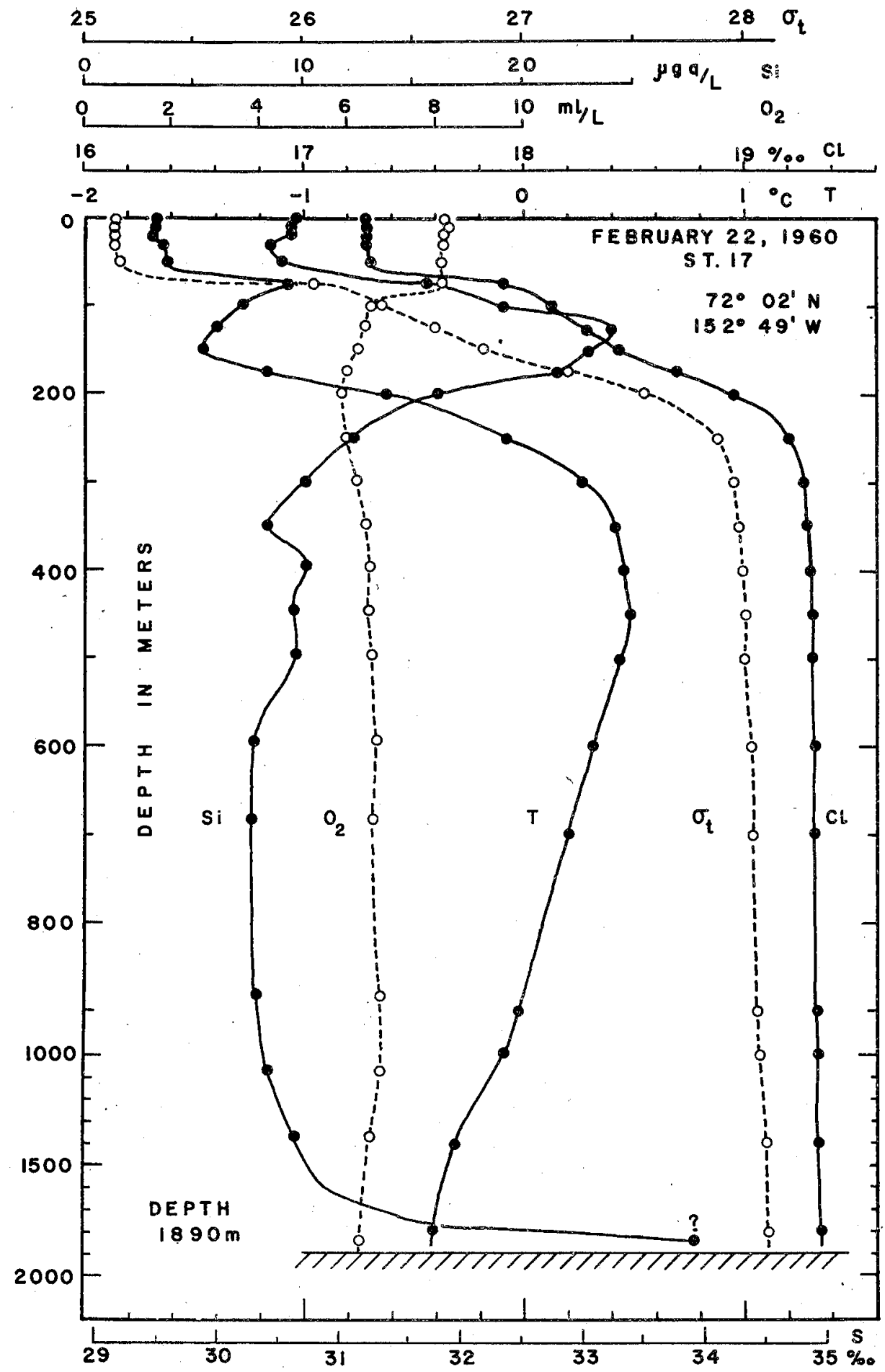

Fig. 6c. Vertical distribution of temperature, density, and chemical elements at Station 17, February 22, 1960. 


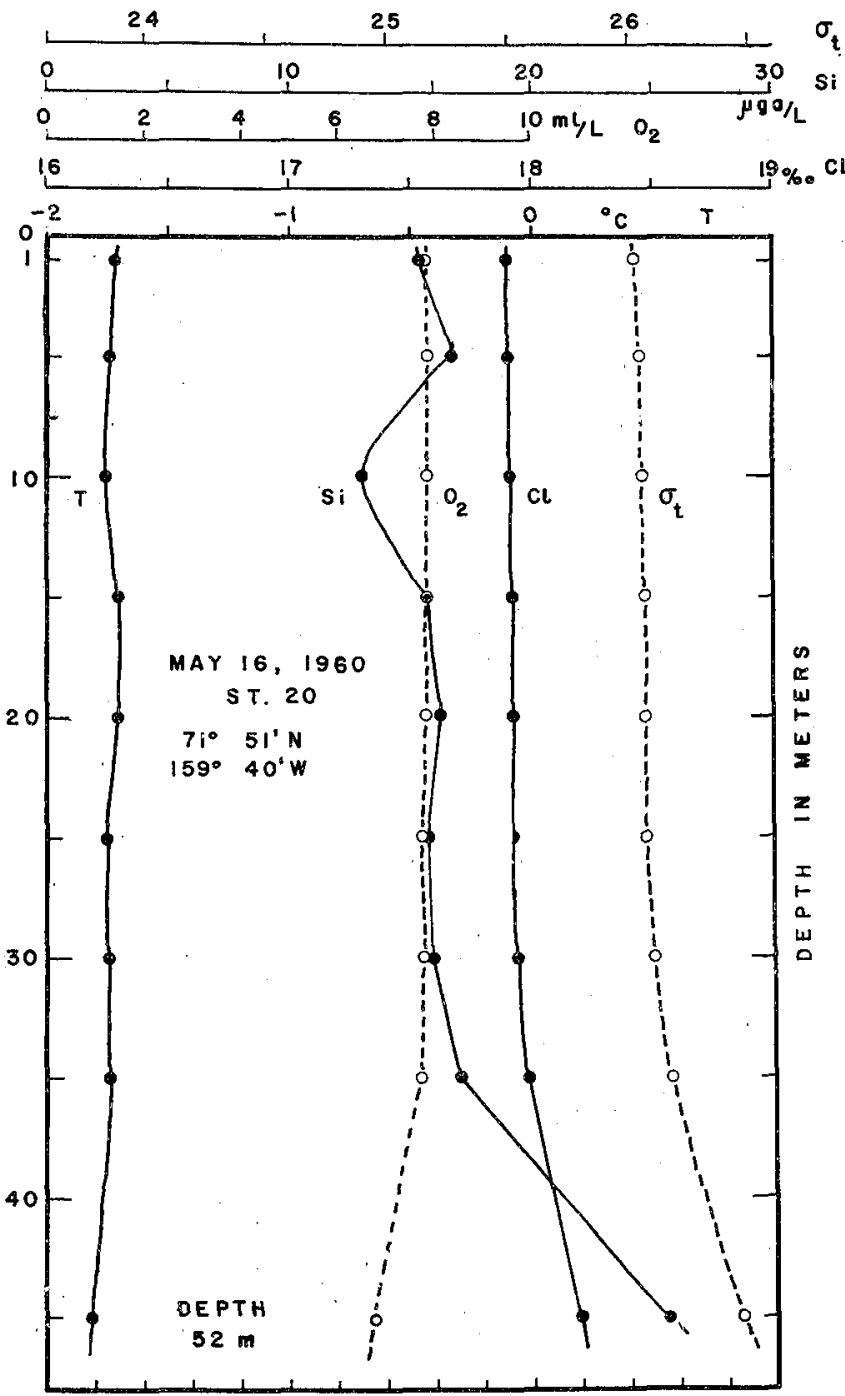

Fig. 6 d. Vertical distribution of temperature, density, and chemical elements at Station 20, May 16, 1960. 


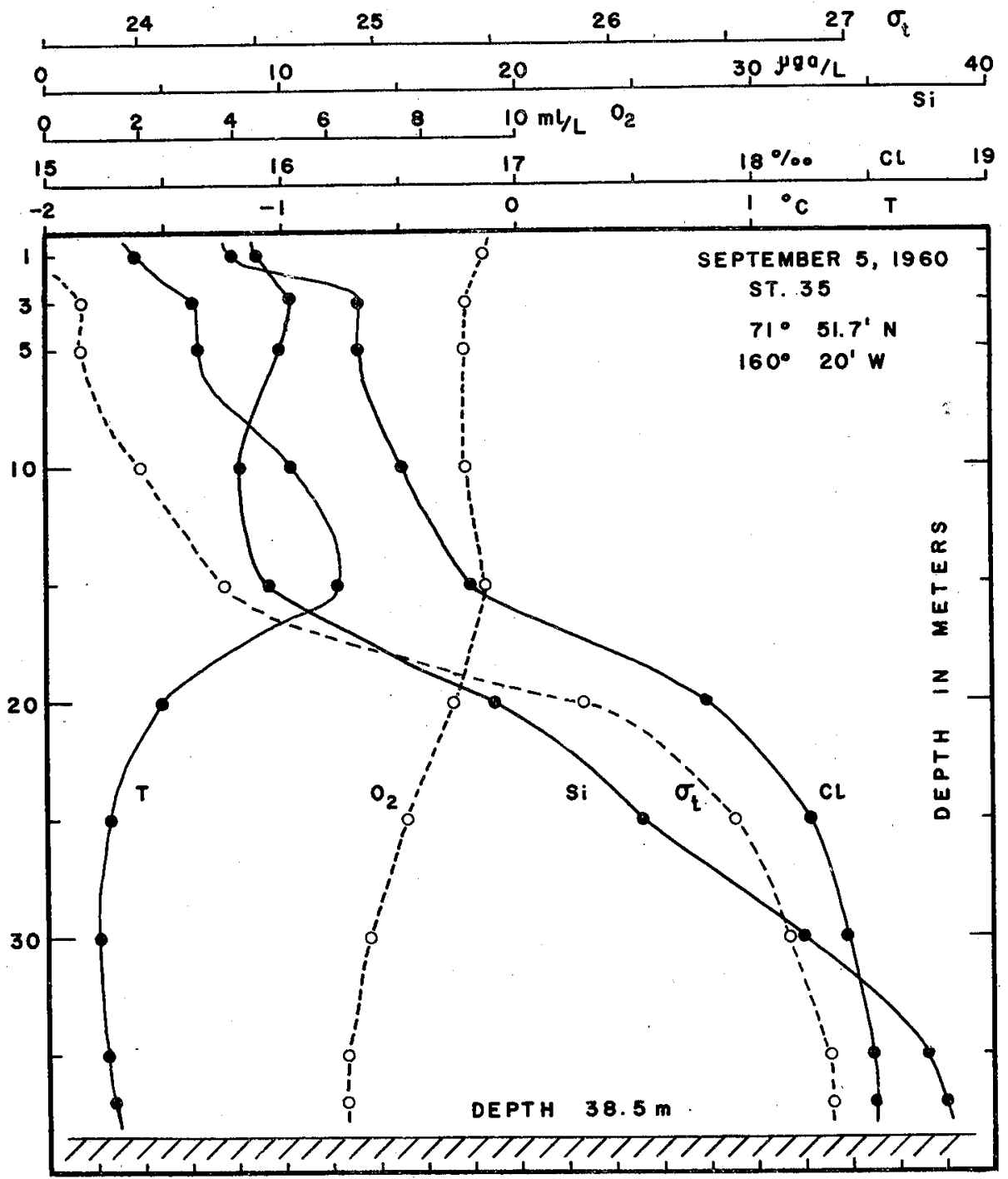

Fig. 6e. Vertical distribution of temperature, density, and chemical elements at Station: 35, September 5, 1960. 

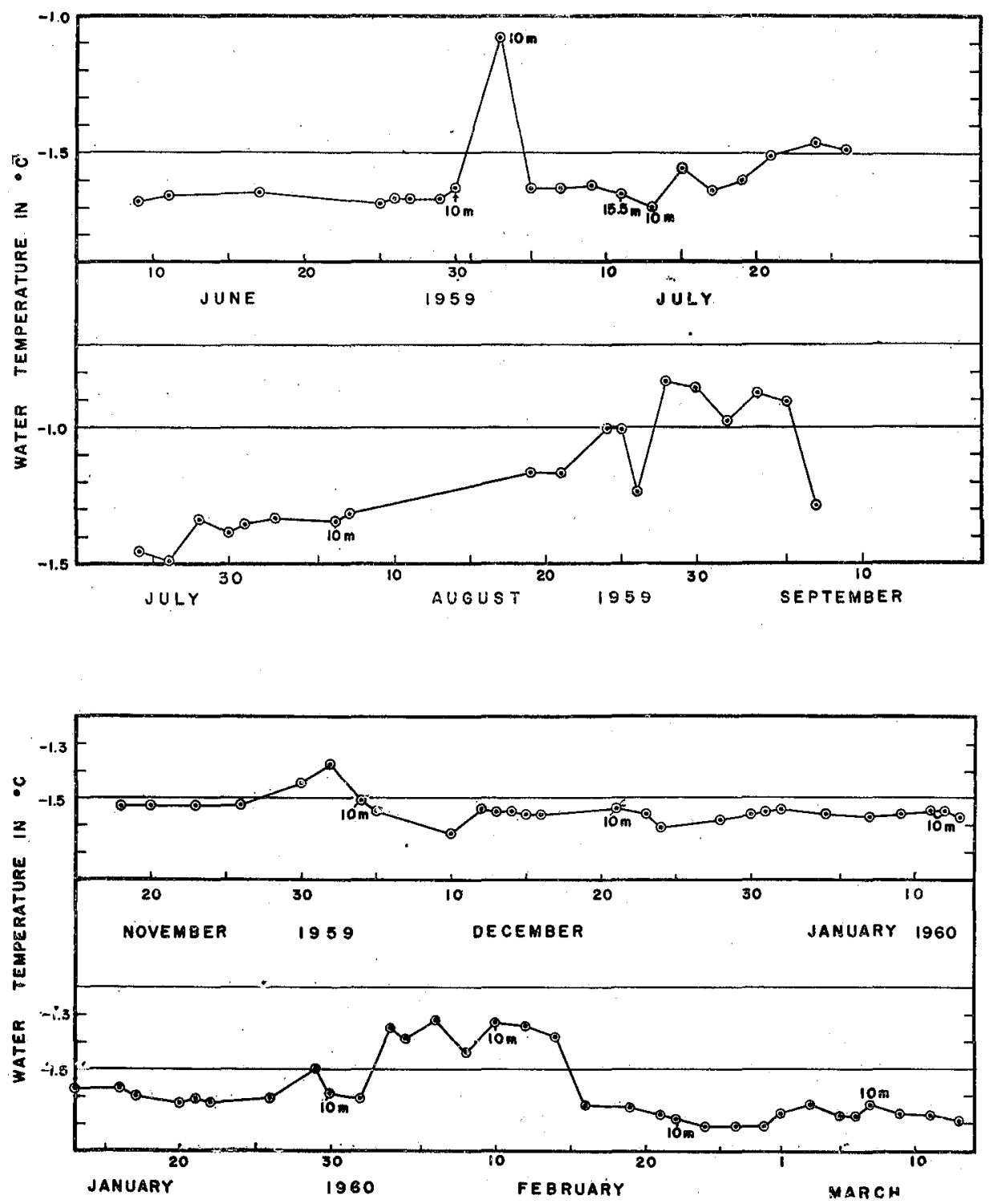

Fig. 7 a. Annual variation of temperature (at 15 meters except where noted otherwise). June 1959-September 1960. 

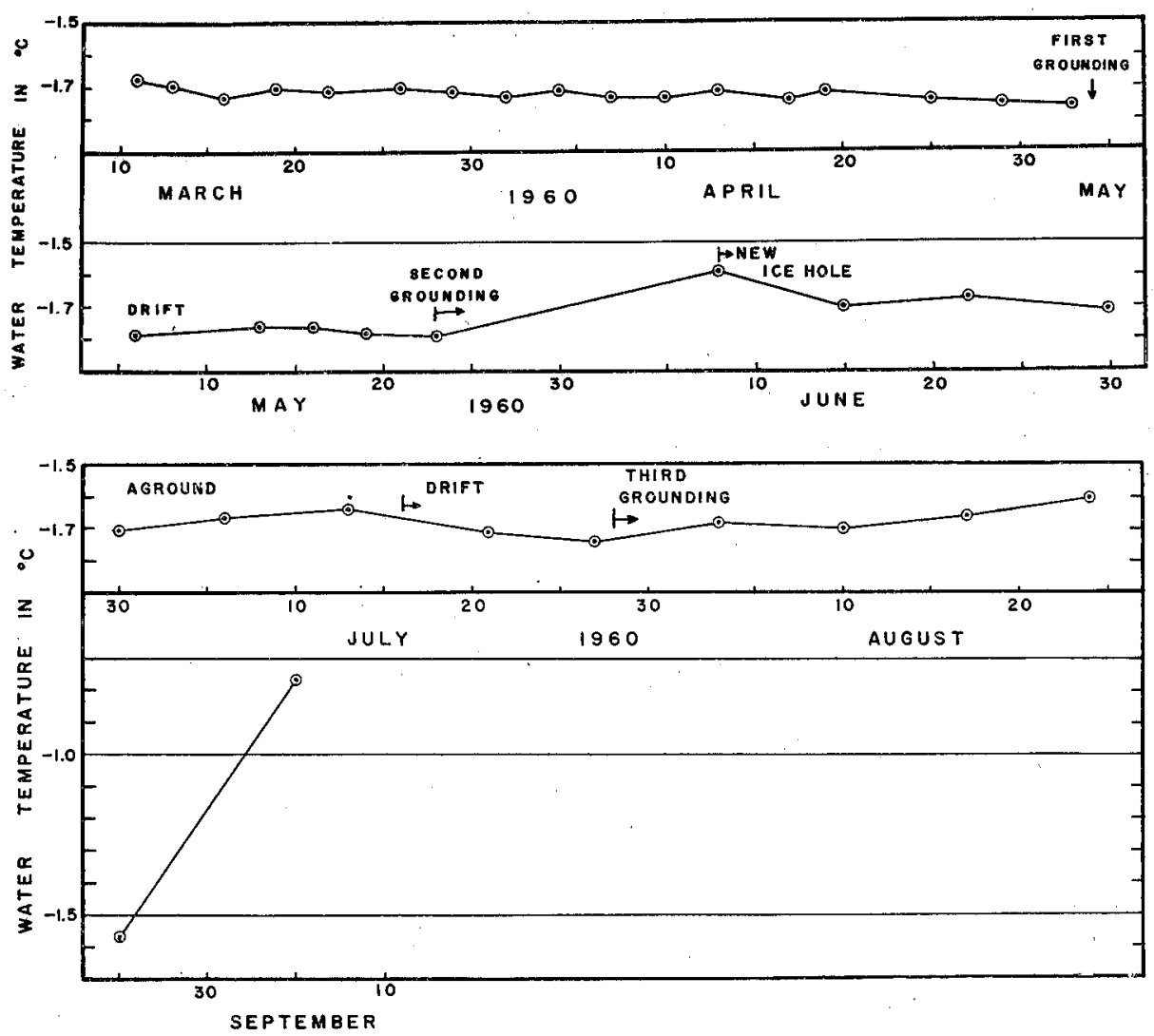

Fig. 7b. Annual variation of temperature (at 15 meters except where noted otherwise). June 1959--September 1960.

water existed from the surface to a depth of about 40 meters. The temperature of this water was quite near the freezing point and supercooling in a small amount was observed. St. 35 (Fig. 6e) was occupied at the beginning of the winter season, but the remnants of heated summer water were still recognized in the upper layers of less than 20 meters. It is to be noted that the supercooling of surface water at 1 meter was observed at this station, showing a value of $-1.62^{\circ} \mathrm{C}$ (freezing point $-1.55^{\circ} \mathrm{C}$ for $\mathrm{Cl}=15.79 \%$ ).

On the basis of the temperature data at 15 meters which were taken as the control for BT casts, the annual variation at the surface will be as presented in Fig. 7. The temperatures read at 15 meters, in some occasions at 10 or 15.5 meters, indicated an annual change of small amplitude, say, $0.2^{\circ}-0.3^{\circ} \mathrm{C}$. With the exception of the higher temperature of $-1.08^{\circ} \mathrm{C}$ recorded on July 3,1959 , when the melt water was channeled into the ice-hole, a temperature of about $-1.7^{\circ} \mathrm{C}$ in the early part of June rose to $-0.84^{\circ} \mathrm{C}$ at the end of August. As the highest mean monthly air temperature was recorded in June, the time lag of water temperature at 15 meters in response to the 
air temperature appeared to be about 2.5 months. It was likely that the melting of ice during the summer was the primary factor in the increase of temperature at 15 meters. The concentration of pack ice around the T-3 might have exerted some influence upon the temperature at surface layers. The mixing of water due to the wind and the advection of water from another source may be secondary factors which change the scheme of annual variation of temperature. During the summer of 1959, the distribution of pack ice surrounding $\mathrm{T}-3$ was not observed. So far as the visual observation within a range of few miles from the hydro-station was concerned, no remarkable open sea was recognized.

No observation of temperature was made between September and November because of the trouble with the winch. In the winter season of $1959 / 1960$ the temperature did not show any remarkable change, with the exception of small increase of a range of $0.2-0.3^{\circ} \mathrm{C}$. The temperature fluctuation shown in Fig.7 suggests that a very strong blizzard caused the intensive vertical mixing of water in the upper layers. The temperature increase during and after the blizzard was reported by MuGurUMA (1961).

With the advance of the winter the open waters are covered by the newly-formed ice. The ice concentration in the early part of 1960 seemed to be $10 / 10$, because the $\mathrm{T}-3$ drifted in the offing less than 100 miles from the coast. Consequently, the temperatures observed at 15 meters did not show any prominent change until the end of May 1960 (Fig. 7). In almost all cases the temperature remained $-1.7^{\circ} \mathrm{C}$.

In the summer of 1960, heavy melting of ice was perceived at about June 22. It should, again, be noted that the temperature observation at this occasion was carried out on the continental shelf in 50 meters of water. The ablation season of 1960 virtually ceased in the middle of August. Even within this time, no remarkable rise in temperature was observed, perhaps the vertical mixing did not reach to 15 meters. After the breaking off of pack ice from Colby Bay on August 27, a very remarkable increase of temperature to $-0.77^{\circ} \mathrm{C}$ was observed. It is quite possible that the warm surface water in the offshore intruded into the Colby Bay area after that ice breaking.

The distribution of temperature in a vertical section through St. 4 to St. 17 is shown in Fig. 8. As those stations were occupied during several months, the temperature distribution shown in Fig. 8 should be interpreted as having a dual character in terms of time and space. However, excepting the surface layer, the temperature change at subsurface layers is small in locality and in season, like the situation in the deep water of the seas in the middle latitudes. As mentioned before, the annual change of temperature at the surface layer, particularly the change due to the melting of ice, will also be recognized in Fig. 8. The effect of melting of ice on the surface temperature was clearly observed at the stations taken in the summer of 1960 . This situation is to be seen in Fig. 9, in which the occupied stations were very close together.

In Fig. 9 the temperatures measured in May showed that the winter convection took place down to the bottom of the shallow continental shelf. In the middle of the ablation season the heated surface water with positive temperatures appeared at 


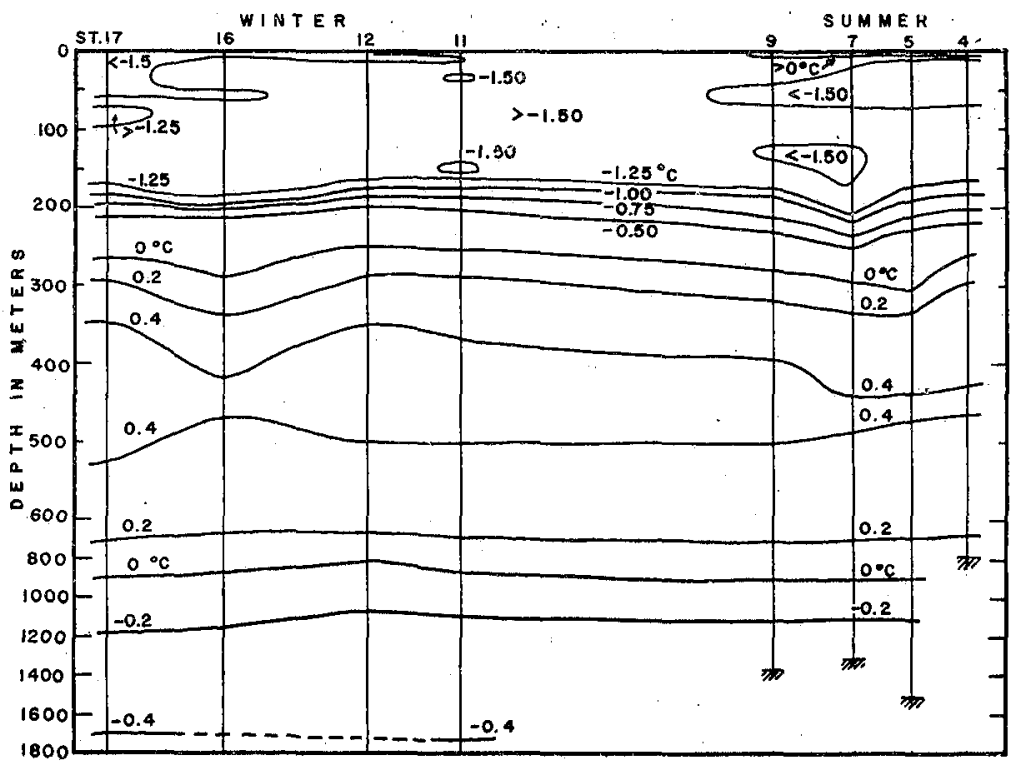

Fig. 8. Distribution of temperature in a vertical section between St. 4 and St. 17 at T-3.

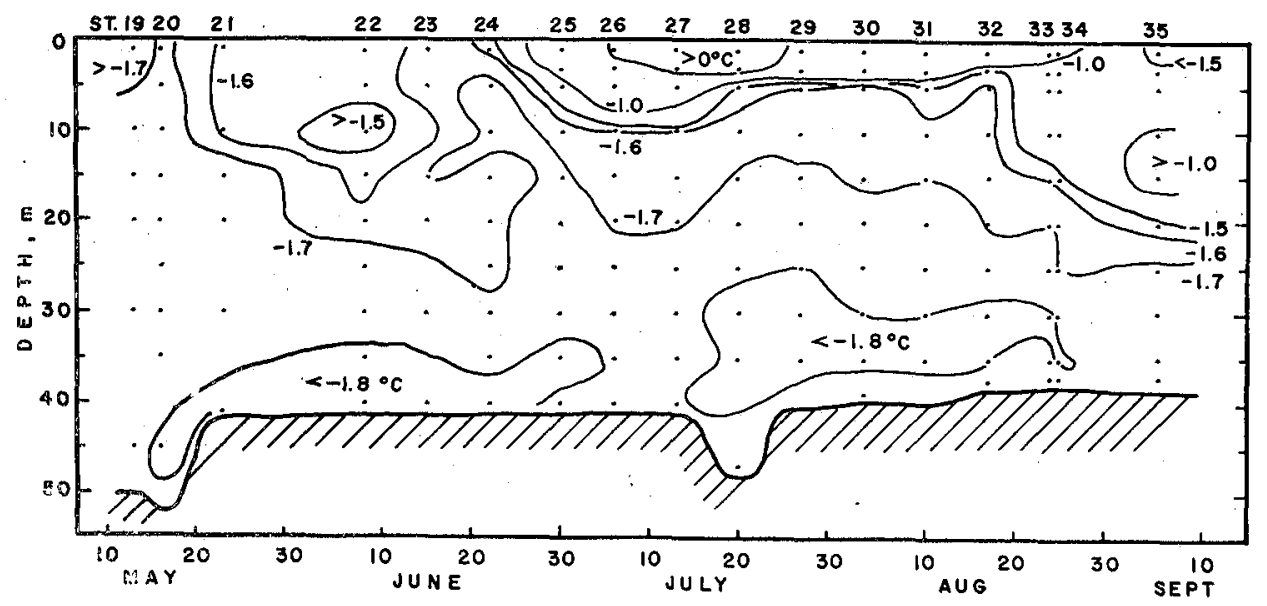

Fig. 9. Distribution of temperature in a vertical section between St. 19 and St. 35 at T-3. 
Sts. 26, 27 and 28. The slightly warm waters found at 10 meters depth of St. 22 may be attributed to the horizontal advection of warm water from another source or to the difference in the position of stations. Actually, the T-3 drifted about 17 miles between May and July during which time St. 22 was taken. It should be said, in general, that the temperatures in shallow waters are very low, with the exception of the heated top layer in the summer. The formation of this homogeneous water may undoubtedly be attributed to the intensive winter vertical convection due to the formation of winter ice. In contrast to the temperatures at 50 meters depth observed at Sts. 1-18, the bottom temperatures at the stations on the shelf are fairly low, being near at the freezing point. This suggests the presence of different water masses at a level of 50 meters at these two localities; the one is offshore and the other is a water mass positioned on the shallow shelf. A further discussion will be given in a later chapter.

It is worthy of note that a slightly warm interlayer was found at 75 meters. This has already been shown in Fig. 5 and Fig. 8. In order to examine this warm interlayer, data from other sources should be presented. In Fig. 10 the locations of oceanographic stations to be analyzed are shown. The warm interlayer was first recognized at the stations of SP-2 in $1950-1951$. Exceptionally warm water of $-0.70^{\circ} \mathrm{C}$ was found at 75 meters at St. 1 of SP-2 which was in proximity to the north of Bering Strait. The Russian researchers attributed this condition to the intrusion of warm Pacific water into the Arctic Basin, particularly of the Pacific side (GuDKOVICH 1955).

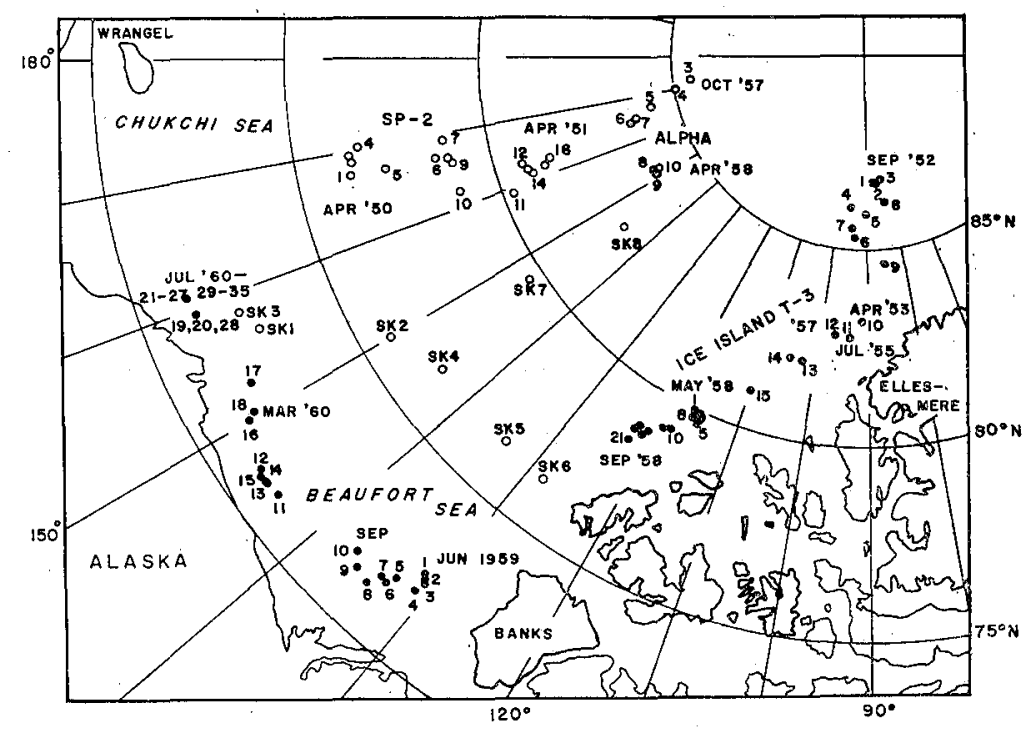

Fig. 10. Locations of oceanographic stations.

SP-2: The Soviet Drift Station "SP-2" in 1950-1951. SK : Project Skijump in 1951-1952. ALPHA: I. G. Y. Drift Station Alpha. Ice Island T-3: I. G: Y. Drift Station Bravo. 
The data collected at the stations of Project Skijump in 1951-1952 also indicated the presence of this interlayer. WORTHINGTON (1953) stated that the negative thermal gradients between 50 and 150 meters had resulted from the last remnants of a seasonal thermocline. The temperature characteristics in regard to warm interlayer observed at many stations in the Pacific side of the Arctic Ocean will be shown below.

In analyzing the oceanographic data at the stations shown in Fig. 10, the oceanographic stations were grouped into several parts in accordance with their locations and the time of occupation. The mean values of temperature maxima of interlayers found at about 75 meters in each group, with their maximum and minimum vales, were presented in Table 1 . In Table 1 the differences in temperatures $(\Delta T)$ between

Table 1. Temperature characteristics of warm interlayer (Pacific Upper Intermediate Water) in the Pacific side of the Arctic Ocean

\begin{tabular}{|c|c|c|c|c|c|c|}
\hline \multirow{2}{*}{$\begin{array}{l}\text { Expedition } \\
\text { and } \\
\text { Station Nos. }\end{array}$} & \multicolumn{3}{|c|}{ Temperatures } & \multirow[b]{2}{*}{$\begin{array}{l}\Delta \mathrm{T} \\
\left({ }^{\circ} \mathrm{C}\right)\end{array}$} & \multirow{2}{*}{$\begin{array}{c}\text { Mean } \\
\Delta \mathrm{T} \\
\left({ }^{\circ} \mathrm{C}\right)\end{array}$} & \multirow[b]{2}{*}{ Remarks } \\
\hline & $\begin{array}{c}\text { Maximum } \\
\left({ }^{\circ} \mathrm{C}\right)\end{array}$ & $\begin{array}{c}\text { Mean } \\
\left({ }^{\circ} \mathrm{C}\right)\end{array}$ & $\begin{array}{c}\text { Minimum } \\
\left({ }^{\circ} \mathrm{C}\right)\end{array}$ & & & \\
\hline $\begin{array}{c}\text { Ice Island } T-3 \\
1952-1955 \\
\text { St. } 2-9\end{array}$ & -1.19 & -1.25 & -1.32 & $0.09-0.28$ & 0.12 & $\begin{array}{l}\text { No gradient } \\
\text { at Sts. } 1, \\
10,11\end{array}$ \\
\hline $\begin{array}{c}1957-1958 \\
\text { St. } 13,13 \text { a, } \\
14,17\end{array}$ & -1.27 & -1.38 & -1.42 & $0.03-0.07$ & 0.06 & \\
\hline $\begin{array}{c}1958 \\
\text { St. } 6,8,12, \\
15,18-21\end{array}$ & $-1: 34$ & -1.37 & -1.39 & $0.01-0.09$ & 0.04 & \\
\hline $\begin{array}{l}1959 \\
\text { St. 3-9 }\end{array}$ & -1.27 & -1.38 & -1.42 & $0.03-0.18$ & 0.09 & \\
\hline $\begin{array}{l}1959-1960 \\
\text { St. } 11-18\end{array}$ & -1.08 & -1.26 & -1.44 & $0.05-0.39$ & 0.23 & \\
\hline $\begin{array}{l}\text { Station Alpha } \\
\text { St. 3-10 }\end{array}$ & -1.28 & -1.31 & -1.38 & $0.02-0.31$ & 0.16 & \\
\hline $\begin{array}{l}\text { Project } \\
\text { Skijump } \\
\text { St. } 1-8\end{array}$ & -0.92 & -1.18 & -1.34 & $0.14-0.59$ & 0.30 & $\begin{array}{l}\text { No gradient } \\
\text { at St. } 3\end{array}$ \\
\hline $\begin{array}{l}\text { SP-2 } \\
\text { St. } 1-16\end{array}$ & -0.70 & -1.07 & -1.17 & $0.26-0.74$ & 0.42 & \\
\hline
\end{tabular}

the top of gradient usually found at 75 meters and at the bottom of gradients at 100-150 meters are included.

At the stations taken at $\mathrm{T}-3$ in 1957-1958, especially in the summer of 1958 , the warm interlayer did not appear prominently (CoLlin 1959). The differences in temperature, $\Delta T$, were in a range of $0.01^{\circ}-0.09^{\circ} \mathrm{C}$ at these stations, which indicates that these values are less than that of other stations located in the western and southern part of the Pacific side. The warm interlayer appeared distinctly at the stations taken at SP-2 (1950-1951), Project Skijump (1951-1952), and at Sts. 11-18 of T-3 in 1959-1950, the maximum temperatures at these stations were $-0.70^{\circ},-0.92^{\circ}$, and $-1.08^{\circ} \mathrm{C}$ re- 
spectively. The data taken at T-3 in the earlier years, between 1952 and 1955, also indicated the penetration of a warm interlayer even in the vicinity of the North Pole. It is to be remarked that at stations taken at $\mathrm{T}-3$ in 1959 (Sts. 3-9) the temperature of the interlayer is $-1.38^{\circ} \mathrm{C}$ in average $\left(\Delta T=0.09^{\circ} \mathrm{C}\right)$ and the average temperature at Sts. $11-18$ is $-1.26^{\circ} \mathrm{C}\left(\Delta T=0.23^{\circ} \mathrm{C}\right)$. Consequently, it is very likely that the warm interlayer at 75 meters originates from the Bering Sea, moving along the Alaskan coast in the southern Chukchi Sea, that it flows northward to the area of North Pole, then is turned southward by the large anticyclonic eddy. This circulation scheme of interlayer may, of course, be changed by seasons and by years. In the course of flow, the interlayer may partly be mixed with the Arctic Surface Water and the underlying Atlantic Water. However, the very stable pyconocline existing between 100 and 200 meters will not assist in developing a mixing with the Atlantic Water.

The influence of an exceedingly warm summer should be taken into the consideration of the formation of these warm interlayers as reported by WORTHINGTON (1953). However, the penetration of warm water heated in the summer is not likely taking place in such a depth of 75 meters, because a very stable pycnocline exists between the surface and 20-30 meters. The winter vertical convection seems to be interrupted by this pycnocline and, even in a very cold winter, the depth of vertical convection will be less than 50 meters. With reference to this subject, a somewhat more detailed discussion will be offered in a later chapter.

The Atlantic Water with positive temperature is found at all deep stations shown in Fig. 10. On the basis of the same data compiled in Table 1, the temperature characteristics of Atlantic Water are shown in Table 2. The mean values of tempera-

Table 2. Characteristics of Atlantic Water in the Pacific side of the Arctic Ocean

\begin{tabular}{|c|c|c|c|c|c|}
\hline & \multicolumn{3}{|c|}{ Temperature } & \multirow{2}{*}{$\begin{array}{l}\text { Numbers of } \\
\text { Observations }\end{array}$} & \multirow{2}{*}{$\begin{array}{c}\text { Mean depth of } \\
\text { temperature } \\
\text { maxima }(\mathrm{m})\end{array}$} \\
\hline & $\begin{array}{c}\text { Minimum } \\
\left({ }^{\circ} \mathrm{C}\right)\end{array}$ & $\begin{array}{c}\text { Mean } \\
\left({ }^{\circ} \mathrm{C}\right)\end{array}$ & $\begin{array}{l}\text { Maximum } \\
\left({ }^{\circ} \mathrm{C}\right)\end{array}$ & & \\
\hline $\begin{array}{l}\text { Ice Island T-3 } \\
1959-1960 \\
\text { St. } 3,5-9\end{array}$ & 0.40 & 0.42 & 0.45 & 6 & 450 \\
\hline St. $11-18$ & 0.40 & 0.45 & 0.52 & 8 & 450 \\
\hline $\begin{array}{l}1952-1955 \\
\text { St. } 12-17\end{array}$ & 0.36 & 0.48 & 0.52 & 11 & 410 \\
\hline $\begin{array}{l}1957-1958 \\
\text { St. } 12-17\end{array}$ & 0.33 & 0.36 & 0.40 & 6 & 454 \\
\hline St. $\begin{array}{r}1958 \\
2-21\end{array}$ & 0.38 & 0.42 & 0.44 & 19 & 452 \\
\hline $\begin{array}{l}\text { Station Alpha } \\
\text { St. 3-8 }\end{array}$ & 0.40 & 0.46 & 0.50 & 6 & 432 \\
\hline Project Skijump & 0.37 & 0.46 & 0.52 & 6 & 500 \\
\hline $\mathrm{SP}-2$ & 0.52 & 0.59 & 0.68 . & 15 & 453 \\
\hline
\end{tabular}

Remark: Chlorinity is nearly. $19.3 \%(\mathrm{~S}=34.9 \%)$ and $\sigma_{t}=28.00$ at all stations cited above. 
ture maxima, the extreme values of temperature maxima in grouped stations, the numbers of observations, and the mean depths of temperature maxima are tabulated. The chlorinity values at the depths of temperature maxima were $19.3 \%$ at all stations, consequently the density in $\sigma_{t}$ was nearly 28.0 .

Table 2 indicates that the temperature maxima at $\mathrm{T}-3$ stations occupied at the western part of the Beaufort Sea (Sts. 11-18) were slightly higher than those at the eastern stations (Sts. 3, 5-9). This would support an inference that the Atlantic Water is flowing eastward, perhaps along the Eurasian and American continents, in the southern Beaufort Sea provided that the decrease in average temperatures of Atlantic Water was resulted from the advective motion during which the heat was lost by the vertical mixing. The temperatures of Atlantic Water at the stations occupied in the offings of the Canadian Archipelago are usually low, particularly at the stations taken in 1957-1958 from T-3. This will suggest that the Atlantic Water is penetrating into the Arctic Basin along the Eurasian continent, not flowing southwards along the American Continent.

In spite of the fact that the oceanographic stations of Alpha are located in the proximity of North Pole, the temperatures of Atlantic Water observed at Alpha were lower than those at SP-2. This will give added support to the explanation that the main body of Atlantic Water is circulating along the Eurasian continent and diffusing into the central part of the Pacific side, and finally goes out to the east of Greenland (East Greenland Current). Recently TimofEYev (1960) showed that the main water circulation of Atlantic Water is in a spreading and diffusing type of eastward motion, mostly along the continental slopes of Eurasia, America and Greenland to the longitude $20^{\circ} \mathrm{W}$. The average speed of the Atlantic Water was estimated to be $3.8 \mathrm{~cm} / \mathrm{sec}$. However, a question is still leff for future study whether the circulation of Atlantic Water is in a scheme described above or in a pattern proposed by WORTHINGTON (1953).

The temperatures of deep waters in the Pacific side showed minima at a depth of about 2000 meters. From this level the temperature increased to the bottom at approximately the rate of adiabatic heating; but the computed potential temperatures in these layers showed that the deep waters are in a condition of stable stratification to the bottom. Table 3 shows the computed potential temperatures at very bottom waters of deep stations in the Pacific side.

Table 3 indicates that the potential temperatures of bottom waters are in a range of -0.50 to $-0.53^{\circ} \mathrm{C}$; the value of $-0.48^{\circ} \mathrm{C}$ at SP-2 station No. 11 seems to be somewhat high. It will be concluded that water with an average potential temperature of $-0.52^{\circ} \mathrm{C}$ is occupying the bottom of the Beaufort Basin in the depths more than 2000 meters.

In connection with the origin of the bottom water in the Beaufort Basin, an analysis of bottom temperature will next be discussed. The average temperatures at 
Table 3. Potential temperatures of bottom waters in the Pacific side of the Arctic Ocean

\begin{tabular}{ccccc}
\hline $\begin{array}{c}\text { Expedition } \\
\text { designation }\end{array}$ & $\begin{array}{c}\text { Station } \\
\text { No. }\end{array}$ & $\begin{array}{c}\text { Depth } \\
(\mathrm{m})\end{array}$ & $\begin{array}{c}\text { Temperature } \\
\text { in situ } \\
\left({ }^{\circ} \mathrm{C}\right)\end{array}$ & $\begin{array}{c}\text { Potential } \\
\text { temperature } \\
\left({ }^{\circ} \mathrm{C}\right)\end{array}$ \\
\hline $\begin{array}{c}\text { SP-2 } \\
(1950-1951)\end{array}$ & 7 & 2670 & -0.35 & -0.50 \\
& 11 & 3233 & -0.28 & -0.48 \\
& 12 & 3015 & -0.34 & -0.52 \\
& 13 & 3266 & -0.32 & -0.52 \\
& 14 & 3526 & -0.30 & -0.52 \\
Project Skijump & 16 & 3816 & -0.26 & -0.51 \\
(1951-1952) & 4 & 3000 & -0.35 & -0.53 \\
Station Alpha & 5 & 2200 & -0.39 & -0.50 \\
(1957-1958) & $5 \mathrm{a}$ & 2978 & -0.35 & -0.53 \\
& 6 & 2754 & -0.36 & -0.52 \\
& 7 & 2269 & -0.40 & -0.52 \\
& 8 & 2650 & -0.38 & -0.53 \\
& 10 & 2740 & -0.37 & -0.52 \\
\hline
\end{tabular}

Table 4. Comparison of potential temperatures in the Atlantic and the Pacific side of the Arctic Ocean.

\begin{tabular}{cccccc}
\hline \multirow{2}{*}{ Depth } & \multicolumn{2}{c}{ Pacific side } & \multicolumn{2}{c}{ Atlantic side } \\
\cline { 2 - 3 }$(\mathrm{m})$ & $\begin{array}{c}\text { Temperature } \\
\text { in situ }\end{array}$ & $\begin{array}{c}\text { Potential } \\
\text { temperature } \\
\left({ }^{\circ} \mathrm{C}\right)\end{array}$ & & $\begin{array}{c}\text { Temperature } \\
\text { in situ }\end{array}$ & $\begin{array}{c}\text { Potential } \\
\text { temperature } \\
\left({ }^{\circ} \mathrm{C}\right)\end{array}$ \\
\hline 1000 & -0.11 & -0.15 & -0.25 & -0.29 \\
1500 & -0.36 & -0.43 & -0.59 & -0.66 \\
2000 & -0.40 & -0.50 & -0.74 & -0.84 \\
2500 & -0.38 & -0.52 & -0.79 & -0.92 \\
3000 & -0.34 & -0.52 & -0.75 & -0.92 \\
3500 & -0.31 & -0.53 & -0.76 & -0.97 \\
4000 & - & - & -0.70 & -0.96 \\
4500 & - & - & -0.70 & -1.03 \\
\hline
\end{tabular}

depths lower than 1000 meters in the Atlantic and Pacific sides of the Arctic Ocean were given by TIMOFEYEV (1960). On the basis of this data, the vertical distribution of potential temperature is computed (Table 4 ).

The temperatures at 1000 and 2000 meters in the Pacific side given by TIMOFEYEV are slightly higher than those of $\mathrm{T}-3$ in 1959-1960. At $\mathrm{T}-3$ stations a minimum of $-0.43^{\circ} \mathrm{C}$ at 2000 meters was obtained in average. The bottom potential temperature of $-0.53^{\circ} \mathrm{C}$ given in Table 3 and Table 4 suggests that the deep waters in the Pacific 
side correspond to the water at a depth of about 1300 meters of the Atlantic side. This will indicate that the Lomonosov Range, which divides the Arctic Ocean into two depressions, should have an effective sill depth of 1300 meters. As was shown in Fig. 1 the depths on the Lomonosov Range are less than 1500 meters in the greater portion of the range. It was reported that the shallowest depth of 954 meters was recorded (GORDIYENKO and LAKTIONOV 1960). The character of bottom temperatures, in relation to abyssal circulation, formation of bottom water, and water circulation in deep trench, has been investigated in the Pacific and the Atlantic Ocean. Sufficient data in the Arctic Ocean are not available at the present writing to draw a conclusive picture on these problems.

It is believed that the bottom water is formed in the Norwegian Sea in consequence of winter-time vertical convection. The motion of this water is also considered to be not different from the circulation of sub-surface water. Another possibility as to the formation of bottom water is that comparatively dense water may be formed at the coastal shelf region where the winter vertical convection takes place down to the bottom and may descend along the continental slope to the bottom of the basin. This process of bottom water formation is recognized in the Antarctic Ocean, especially in the Weddel Sea. 'If the same process is taking place in the Arctic Ocean, the seas on the continental slopes will prove to be the area of its occurrence. However the temperature-chlorinity relationship of the waters in this area did not show any confirmative evidence in support of this conjecture. This is to be treated in a later chapter dealing with the water masses of the Arctic Ocean.

\section{Distribution of Chlorinity and Density}

It is known that the following international relationship, Knudsen's formula, between salinity and chlorinity is not necessarily valid for highly diluted sea water widely found at the surface of the Arctic Ocean.

$$
\text { Salinity }=0.03+1.805 \times \text { Chlorinity }(\%)
$$

The chlorinity values determined by Knudsen's titration method are used in the present paper to discuss the oceanographical conditions of the Arctic Ocean. As already described, a number of fresh water samples less than $17 \%$ in chlorinity were titrated by Mohr's method. The use of chlorinity values, in a strict sense the content of chloride, will be of value when discussing the brackish surface water. Recently, MUSINA and AVDEYEVICH (1960) made chemical analyses of sea waters sampled the Kara, the Laptev, the East-Siberia, and the Chukchi Seas in regard to the chlorinitysalinity relationship. They concluded that Knudsen's formula is valid for the waters in salinity values from 4 to $35 \%$. Waters with a salinity of less than $4 \%$ are frequently encountered at the surface waters in the summer.

On account of the low temperatures of the waters in the Arctic Ocean, the density is approximately a linear function of chlorinity, especially for the waters colder than 
$0^{\circ} \mathrm{C}$. Hence, the distribution of chlorinity will be discussed in parallel with the density distribution. The values of density in sigma-t $\left(\sigma_{t}=\left(\rho_{t}-1\right) \times 10^{3}\right)$ will be used, where $\rho_{t}$ is the density of sea water at temprature $t$.

The vertical distribution of chlorinity observed at T-3 has already been presented in Figs. $6 \mathrm{a}, \mathrm{b}, \mathrm{c}, \mathrm{d}$ and $\mathrm{e}$. The surface waters at the stations occupied in the summer showed an exceedingly low chlorinity due to the melting of relatively fresh sea ice and the drainage from lakes and streams on $T-3$. The fresh and warm water at the surface is mixed under the action of winds, particularly in the early part of winter, and the thermohaline convection due to ice formation tends to cause the fresh surface layer to vanish. It was remarked that a considerable extension of ice cover existed around the hydro-station in Colby Bay of $\mathrm{T}-3$, thus a plenty of fresh water was always supplied into the ice-hole during the ablation season. Even in the case when T-3 drifted at a considerably large speed, the surface fresh water did not disappear. Complete mixing did not take place within a layer of less than 5 meters. This situation may be recognized from the distribution of temperature and chlorinity presented in Table 5 .

Table 5. Distribution of temperature and chlorinity at surface layers in the summer

(St. $5^{\prime}$, Ice Island T-3, July 9, 1959. Position $71^{\circ} 57.3^{\prime} \mathrm{N}, 132^{\circ} 3^{\prime} \mathrm{W}$ )

\begin{tabular}{ccc}
\hline Depth in meters & Temperature in ${ }^{\circ} \mathrm{C}$ & Chlorinity in \% \\
\hline 0 & 0.10 & - \\
3 & 0.11 & - \\
6 & -1.66 & - \\
9 & -1.62 & - \\
12 & -1.61 & 17.11 \\
14.5 & -1.62 & 17.11 \\
\hline
\end{tabular}

Although the analysis of chlorinity of surface layers ( 0 to 9 meters) was not made on the occasion shown in Table 5 , the temperature profile will suggest that the depth of fresh water is less than 5 or 6 meters. It should be remarked that the average thickness of pack ice in Colby Bay area was about 5 meters and an ice-hole was opened in this pack. Accordingly, the actual thickness of surface fresh water layer may be less than 5 meters at the station on ordinary Arctic Pack and in open waters.

Chlorinity values observed at $\mathrm{T}-3$ were comparatively low even in winter. At St. 11 occupied on November 29, 1959, a fairly low chlorinity of $15.05 \%$ was observed at the surface layers, when the convective mixing due to ice formation had been commenced.

In connection with this situation it should be remarked that not only the melting of ice in the neighborhood of the oceanographic station but the effect of advected waters from other sources, perhaps the run-off from the land, may have been re- 
sponsible for dilution. In the present observations, the island drifted roughly 150 miles within the period of cessation of observation from September to November 1959, during which the T-3 approached to the Alaskan coast. The run-off from the Mackenzie River, Colville River, and even the Yukon River might have exerted some influence upon the surface chlorinity. ANTONOV (1958) estimated the value of annual drainage of $430 \mathrm{~km}^{3}$ from the rivers between Ellesmere Island and Bering Strait, including the run-off from the Yukon River. A total of $1426 \mathrm{~km}^{3} /$ year of continental drainage from the North American Continet and northern Greenland is $32.5 \%$ of the total continental drainage into the Arctic Ocean $\left(4380 \mathrm{~km}^{3} /\right.$ year). Consequently the discharges from the periphery of the Arctic Ocean should not be ignored in analyzing the water, heat, and salt budget of this ocean. The average value of chlorinity at the surface layer $(10 \mathrm{~m}$ ) at the winter stations of T-3 (St. 11, Nov. 1959-St. 18, March 1960) was $16.21 \%$ and never exceeded $18.02 \%$.

The dilution due to the ice melt water in the summer was prominent at the stations taken in 1960. This situation will be recognized in Fig. 11. A very stable

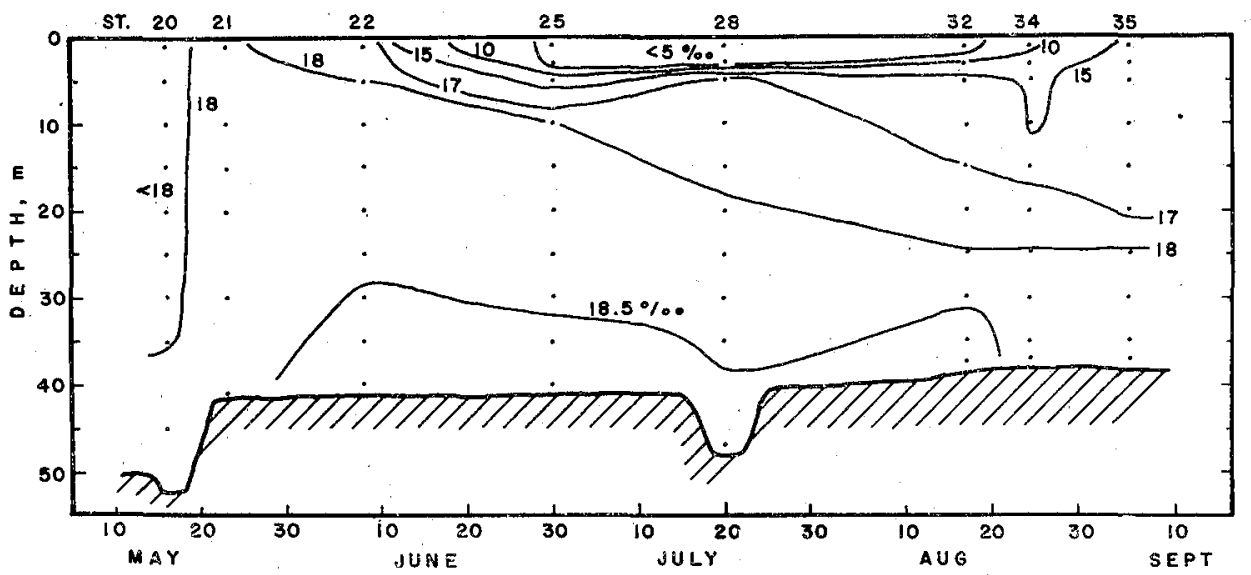

Fig. 11. Distribution of chlorinity in a vertical section between St. 20 and St. 35 at T-3.

stratification of chlorinity persisted at the stations taken in the middle of summer (Sts. 22-34). The homogeneous water found at St. 20 which was taken in the middle of May will suggest that this water appeared as a result of vertical convection which had occurred in the previous winter. The distribution of density, which shows a strong resemblance to that of chlorinity, at these stations is presented in Fig. 12. As mentioned above, the ablation season in 1960 was between late June and the middle of August.

The distribution of chlorinity at the depths below 200 meters was very similar throughout all stations and a slight increase towards the bottom was common. The values ranged at $18.9-19.36 \%$ between 200 and 2000 meters. Due to the restriction of cable observations at depths below 2000 meters could not be made, but the chlorinity 


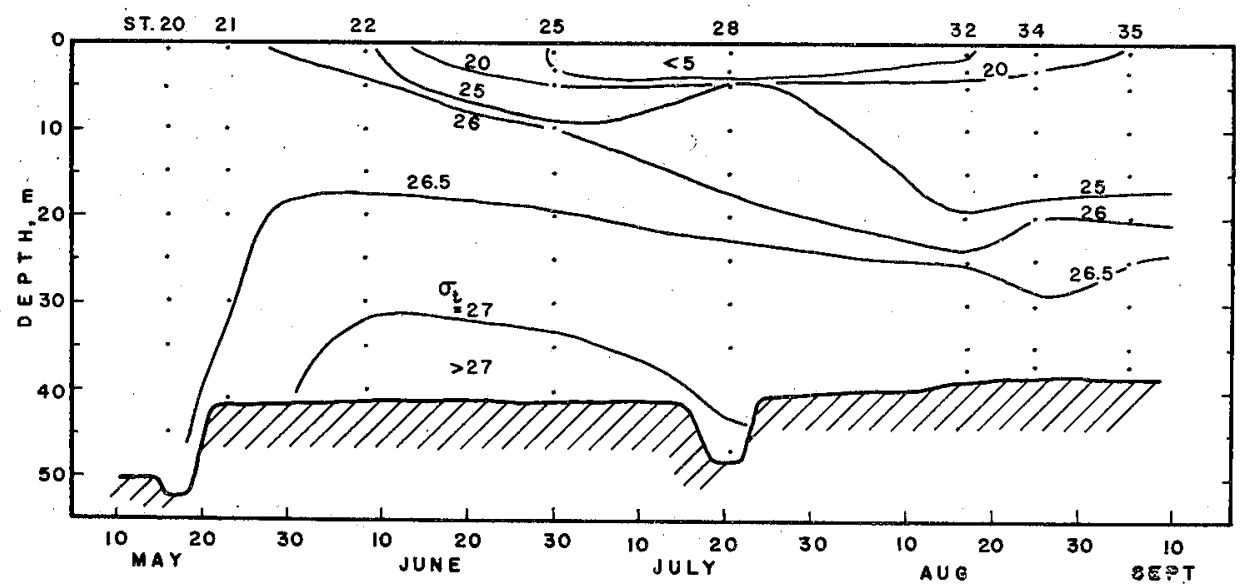

Fig. 12. Distribution of density $\left(\sigma_{t}\right)$ in a vertical section between St. 20 and St. 35 at T-3.

of very bottom waters in the southern Beaufort Sea is deduced to be $19.36 \%$ from the data obtained by other expeditions.

The vertical distribution of density at the representative stations have already been shown in Figs. $6 \mathrm{a}, \mathrm{b}, \mathrm{c}, \mathrm{d}$ and e. A noticeably large gradient in density, especially within the surface layer less than 5 meters, was always observed at stations taken during the ablation period. A large increase in density to the depths was prominent in layers less than 300 meters. Like the distribution of temperature shown in Fig.

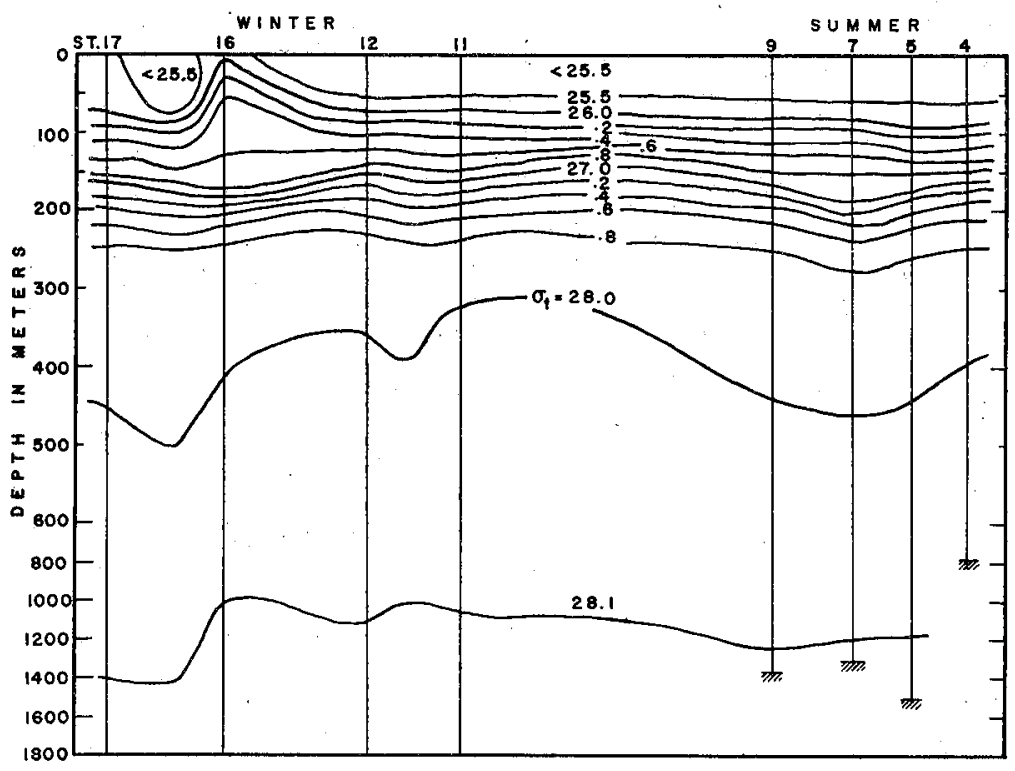

Fig. 13. Distribution of density $\left(\sigma_{t}\right)$ in a vertical section between St. 4 and St. 17 at T-3. 
8, the distribution of density at subsurface layers will be seen from Fig. 13. It should be remarked that Fig. 13 represents the dual character of temporal and spatial distribution in terms of density. The isopycnal of 28.10 is not horizontal even at a depth of 1200 meters. This may partly be attributed to the fact that the present observations were not made simultaneously. An explanation that the circulation of deep waters was in existence may also be permissible.

The vertical convection due to ice formation may be deduced from the distribution in density at St. 17 shown in Fig.6 $\mathrm{c}$ and Fig. 13. The thorough investigation on the process of vertical convection in the initial stage of ice formation was impossible because of the breaking of winch. However, when the observations at St. 11 were made on November 19, 1959, the existence of homogeneous water occupied the layers less than 10 meters deep suggested that the vertical convection had alrady been established at this time of the year. Perhaps, the vertical convection began immediately after the termination of the ablation season.

It is interesting to note that a considerable saline water with a chlorinity of more than $18 \%$ occupied the layer between the surface and 150 meters at St. 16. This situation is indicated in Fig. 13. Station 16 was occupied on February 10, 1960 after a rapid drift which lasted two days with an average speed of 18 miles/day $(38 \mathrm{~cm} / \mathrm{sec})$. This value is exceptionally larger than the average speed of 2 miles/day in the summer of 1959. The chlorinity data at stations taken before and after this drift showed that less saline water appeared in the surface layers; the surface chlorinity values (at $1 \mathrm{~m}$ ) at St. 15 (January 30) and St. 17 (February 22) were 15.6 and $17.3 \%$ respectively. The value of chlorinity at $1 \mathrm{~m}$ at St. 18 was $16.6 \%$. This station was occupied in the vicinity of St. 16 after the reverse drift from St. 17 (see Figs. 4 c, d). The homogeneous saline water at St. 16 may be interpreted as a result of intensive vertical mixing during the rapid drift of the island. It was already mentioned that increase in temperature occurred at 15 meteres depth during blizzard and persisted several days (see Fig. 7). This will also provide evidence of turbulent mixing under the action of wind.

The distance between St. 16 and St. 18 was about 15 miles (see Fig. 4 d). The difference in chlorinity of surface waters at these two stations was significantly large. This may suggest that the horizontal transport of water with a chlorinity of $16.6 \%$ took place at this locality within 25 days from February 10 to March 7 . As the homogeneous water with a chlorinity of $16.6 \%$ occupied the upper 20 meters, it is probable that strong advection took place within this layer. The origin of this desalinified water may be presumed to be remnants of ice melt water formed in other localities and/or the run-off from the coast.

The distribution of density in a vertical direction shown in Figs. 12 and 13 indicates very stable density stratification in the upper layers of less than 300 meters, particularly less than 20-30 meters. The vertical stability of water defined by Hesselberg and Sverdrup is : 


$$
E=\frac{\partial \rho}{\partial t}\left(\frac{d t}{d z}-\frac{d t}{d z}\right)+\frac{\partial \rho}{\partial s} \frac{d s}{d z}
$$

where $d \theta / d z$ is the adiabatic rate of change of temperature with depth; other notations may be self-explanatory. In discussing the stability of upper layers, the following simple equation is widely used:

$$
E^{\prime}=10^{-3} \frac{d \sigma_{t}}{d z}
$$

where $\sigma_{t}$ is the density of water.

In order to examine the scheme of density stratification in the summer and winter, the mean values of temperature and chlorinity, thus the density, were computed for Sts. 3-10 (summer) and Sts. 17-18 (winter). On the basis of these data the vertical stability was computed by equation (2). The results are indicated in Table 6 .

Table 6. Vertical stability at the stations of Ice Island $\mathrm{T}-3$ in .1959-1960

(Unit 18 $8^{8}$ )

\begin{tabular}{ccc}
\hline $\begin{array}{c}\text { Depth } \\
(\mathrm{m})\end{array}$ & $\begin{array}{c}\text { Summer (June-Sept.) } \\
\text { St. 3-10 }\end{array}$ & $\begin{array}{c}\text { Winter (Feb.-March) } \\
\text { St. 17-18 }\end{array}$ \\
\hline 0 & 244400 & -45 \\
10 & 3000 & 50 \\
20 & 1900 & 1150 \\
30 & 1150 & 1030 \\
50 & 2480 & 2940 \\
75 & 1560 & 1220 \\
100 & 1160 & 810 \\
150 & 1120 & 1540 \\
200 & 550 & 920 \\
300 & 50 & 100 \\
400 & & \\
\hline
\end{tabular}

Table 6 shows a very large value in vertical stability at the surface layer in the summer season, being 244,400 . The values are all positive at the levels above 400 meters, indicating a very stable condition. In contrast to the summer fairly small winter values of less than 1000 were obtained within the layers less than 30 meters. When intensive vertical convection took place in winter the stability was nearly zero or negative, which occurred within the layers of less than 10 meters at Sts. 17 and 18. TIMOFEYEV (1960) mentioned that the average depth of convection in the Pacific side of the Arctic Ocean was 40-45 meters and that in the Atlantic side it was less than 75 meters. Hence, the possibility of the occurrence of a warm interlayer due to the remnants of summer heated surface water is unlikely.

To evaluate the stability in the layers below 400 meters, the data of Sts. 9 and 
10 were used to obtain the representative values of temperature and chlorinity in deep water. According to equation (1) the values of vertical stability were computed as shown in Table 7 , in which the values of $E^{\prime}$ are also included.

Table 7. Vertical stability of deep waters in the Pacific side of the Arctic Ocean

\begin{tabular}{cccccc}
\hline $\begin{array}{c}\text { Depth } \\
(\mathrm{m})\end{array}$ & $\begin{array}{c}\text { Temperature } \\
\left({ }^{\circ} \mathrm{C}\right)\end{array}$ & $\begin{array}{c}\text { Salinity } \\
(\%)\end{array}$ & $\begin{array}{c}\text { Density } \\
\left(\sigma_{t}\right)\end{array}$ & $10^{8} \mathrm{E}$ & $10^{8} \mathrm{E}^{\prime}$ \\
\hline 400 & 0.42 & 34.85 & 27.99 & 19.3 & 10 \\
600 & 0.32 & 34.89 & 28.01 & 11.7 & 30 \\
800 & 0.11 & 34.90 & 28.04 & 16.0 & 30 \\
1000 & -0.10 & 34.92 & 28.07 & 9.7 & 8 \\
1500 & -0.34 & 34.96 & 28.11 & 4.0 & 2 \\
2000 & -0.41 & 34.98 & 28.12 & &. \\
\hline
\end{tabular}

Table 7 indicates that the positive values of stability present evidence that the deep water is still in stable stratification despite of the intrusion of warm Atlantic Water. The values obtained by the practical equation (2) are fairly in good agreement with those computed by equation (1). It should be remembered that the inversion of temperature gradient due to warm Atlantic Water between 150 and 450 meters gives negative stability in the temperature term of equation (1). But the contribution of the salinity term in equation (1) is far greater than the temperature term in this layer. The vertical stability of deep waters in the Atlantic side may not differ greatly from that in the Pacific side shown in Table 7.

\section{Distribution of Chemical Elements}

\section{Oxygen Content}

The distribution of dissolved oxygen content and the percentage saturation observed at $\mathrm{T}-3$ is plotted in Fig. 14. The values at Sts. 20-35 are shown by the open circles. The percentage saturation computed by Fox's formula showed supersaturation at the surface layers. It will be seen that the distinct maximum in oxygen appeared always at the surface whilst the minimum of about $6.0 \mathrm{ml} / 1(74 \%)$ was characteristic at about 225 meters. The details of the vertical profile at representative stations will be recognized from Figs. $6 \mathrm{a}, \mathrm{b}, \mathrm{c}, \mathrm{d}$, and e.

The results of oxyged determination in the summer of 1958 at $\mathrm{T}-3$ indicated the occurrence of oxygen minimum at 150 meters with an average value of $6.1 \mathrm{ml} / 1$ while at the bottom it was about $6.4 \mathrm{ml} / 1$ (COLLIN 1959). The data at the stations of SP-2 showed a minimum of $6.2 \mathrm{ml} / 1(74 \%)$ at 200 meters and at SP-4 it was $6.1 \mathrm{ml} / 1(71 \%)$ at 150 meters (MUSINA 1960). The depths of those oxygen minima are fairly close to those at $T-3$ in 1959-1960. It should be kept in mind that there exists difference in locality of observation station with different years. An additional statement should 


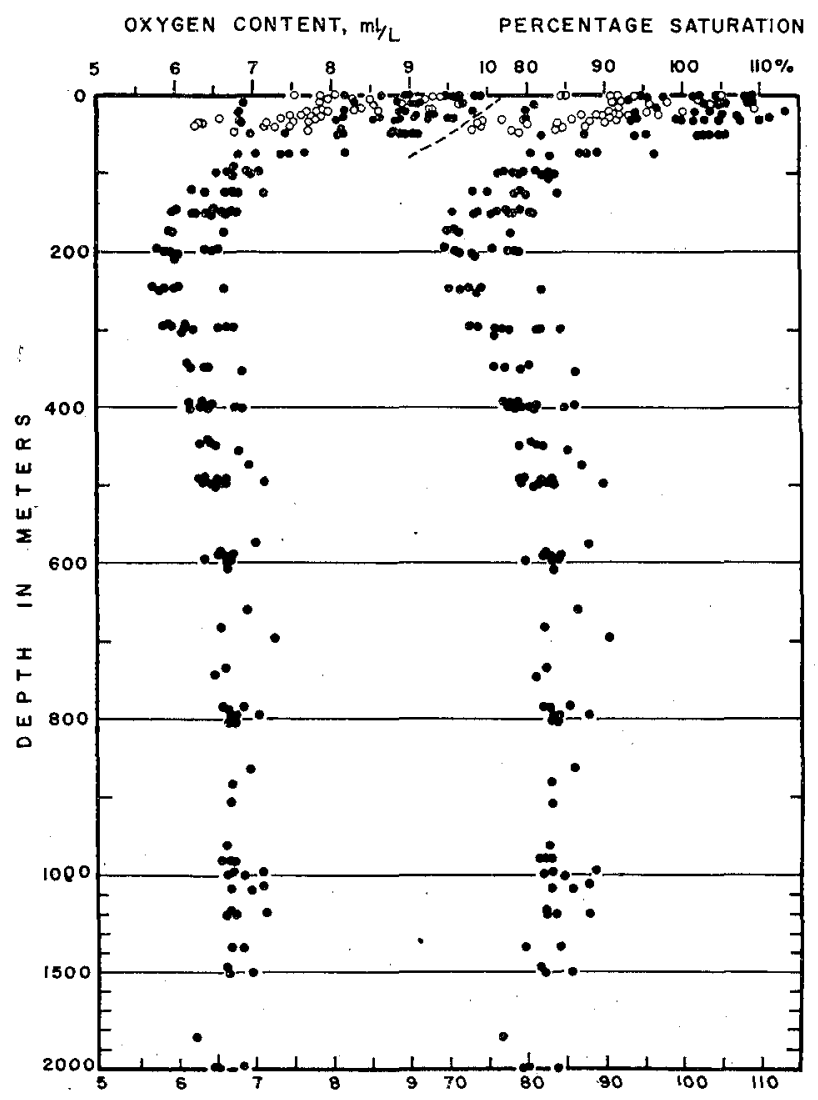

Fig. 14. Vertical distribution of dissolved oxygen content $(\mathrm{ml} / 1)$ and percentage saturation (\%) observed at $\mathrm{T}-3$. Open circles indicate the values at Sts. 20-35.

be made on the distribution of $\mathrm{pH}$; a minimum of 7.6 appeared at 150 meters at $\mathrm{T}-3$ in 1958 and the same feature was observed at SP-2 and SP-4. The observation made on the heterotrophic bacteria at SP-3 in 1954 indicated the maximum accumulation of them at about 100-200 meters (KRISS 1955). At this occasion the penetration of Pacific waters was discernible near the geographic North Pole from microbiological observations. It is likely that the oxygen minimum had resulted from the oxydation process between the relatively warm Pacific and the underlying water. The stable stratification in density will interrupt the rapid sinking of oxygen consuming materials down to the bottom.

Figure 14 also indicates a very slight increass in oxygen content below the minimum layer; a minor maximum of about $6.9 \mathrm{ml} / 1(85 \%)$ is likely to exist at about 800 meters. The same distribution was observed from SP-2 and SP-4 at about 1000 meters with secondary maxima of $6.8 \mathrm{ml} / 1(84 \%)$ and $6.9 \mathrm{ml} / 1(84 \%)$ respectively. Below this level the content decreased gradually towards the bottom where the value 
attained to $6.5 \mathrm{ml} / 1(81 \%)$.

The vertical distribution of oxygen content along the section through St. 4 and St. 17 is shown in Fig. 15 . At St. 9 an oxygen content of $9.90 \mathrm{ml} / 1$ was recorded

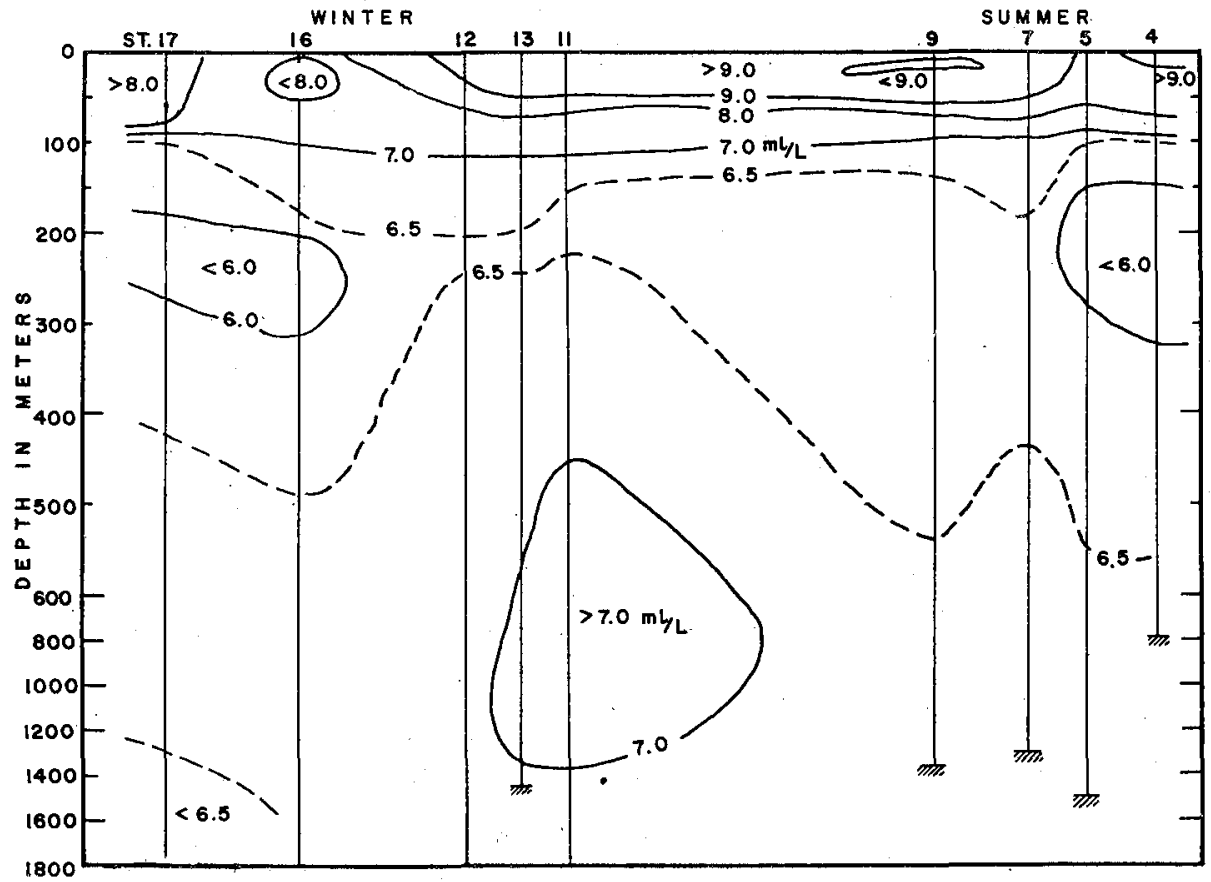

Fig. 15. Distribution of oxygen content $(\mathrm{m} / \mathrm{l})$ in a vertical section between St. 4 and St. 17 at T-3.

at the surface at the end of August, this might be resulted from the high temperature of fresh water. A noticeably small amount of oxygen less than $6.0 \mathrm{ml} / 1$ was observed at the oxygen minimum layer in the spring (Sts: 4 and 5) and late winter stations (Sts. 16 and 17). At depths below 250 meters the content of oxygen at the winter stations was somewhat larger than that of the summer, particularly the contents at the levels of $500-1300$ meters at Sts. 11 and 13 were about $7.0 \mathrm{ml} / 1$.

The distribution of oxygen at the stations on the shallow shelf is illustrated in Fig. 16. The surface layer in the summer season is heated and highly diluted, thus the content of oxygen should be increased. The blooming of plankton will evolve oxygen in the summer season; that may take place above the level of the compensation depth of perhaps less than 30 meters. It is to be noted that the measurements of net photosynthesis by means of the Carbon-14 method at T-3 during the summer of 1957 were made by APOLLONIO (1958). He obtained an average primary production of $0.01 \mathrm{gC} / \mathrm{m}^{2} /$ day over the period of 20 June to 20 August. This is a very low rate of production in comparison with that in the other oceans. The fresh water from the melting of snow and ice will be prohibitive of blooming of phytoplankton. Hence, 


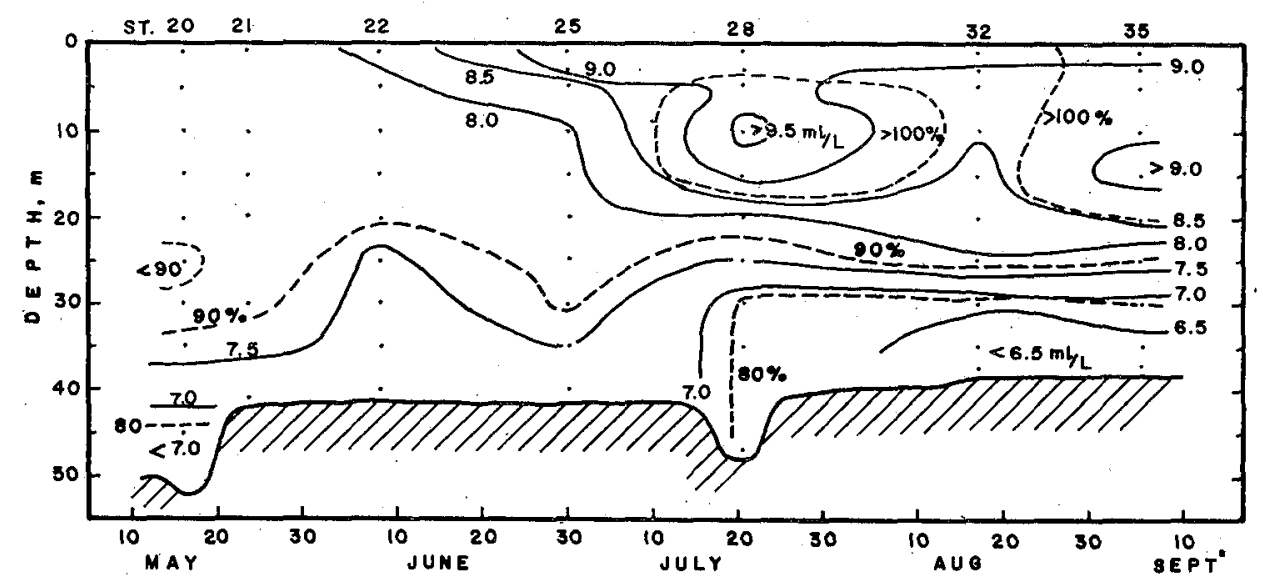

Fig. 16. Distribution of oxygen content $(\mathrm{m} / 1)$ and percentage saturation in a vertical section between St. 20 and St. 35 at T-3.

the increase in oxygen content observed at the stations taken in summer may largely be attributed to physical effects. In view of the intensive solar radiation in tne Arctic summer, the increase in oxygen content due to biological activity should not be ignored however, particularly in the areas free from ice cover.

A considerably small amount in oxygen less than $6.5 \mathrm{ml} / 1$ appeared at the bottom waters of Sts. 32 and 35 on the shelf. That was presumably caused by the advective transport of water from another locality or the creep-up of water at about 200 meters on the shelf.

In connection with the characteristics of water masses and their circulation in the Arctic Ocean, an additional source of information concerning the distribution of oxygen content will be analysed. Plots of density-oxygen relationship are presented in Fig. 17 , in which the density $\left(\sigma_{t}\right)$ on the ordinate should also be interpreted as the chlorinity because of low water temperature. It is to be seen that the waters observed at Sts. 19 to 35 on the shallow shelf have a somewhat greater amount of oxygen than the waters less than 200 meters at the stations occupied in the off-shore area. This will suggest that the water on the continental shelf originated from another source. The waters in the subsurface layers deeper than 300 meters are plotted in a group centered at $6.8 \mathrm{ml} / 1$ oxygen content and 28.1 density. This group represents the Atlantic Water and deep water to a depth of 2000 meters covered by the present observations on $\mathrm{T}-3$.

It has been observed that the oxygen content in the deep layers of the seas in middle latitudes decrease all the way down to the bottom. The Pacific, Atlantic, and the Antarctic oceans have an amount of $3-4 \mathrm{ml} / 1$ in oxygen in the bottom water. In contrast to these small values, the bottom water of the Arctic Ocean contains more than $6 \mathrm{ml} / 1$, even at depths below 3000 meters. As mentioned before, the oxygen 


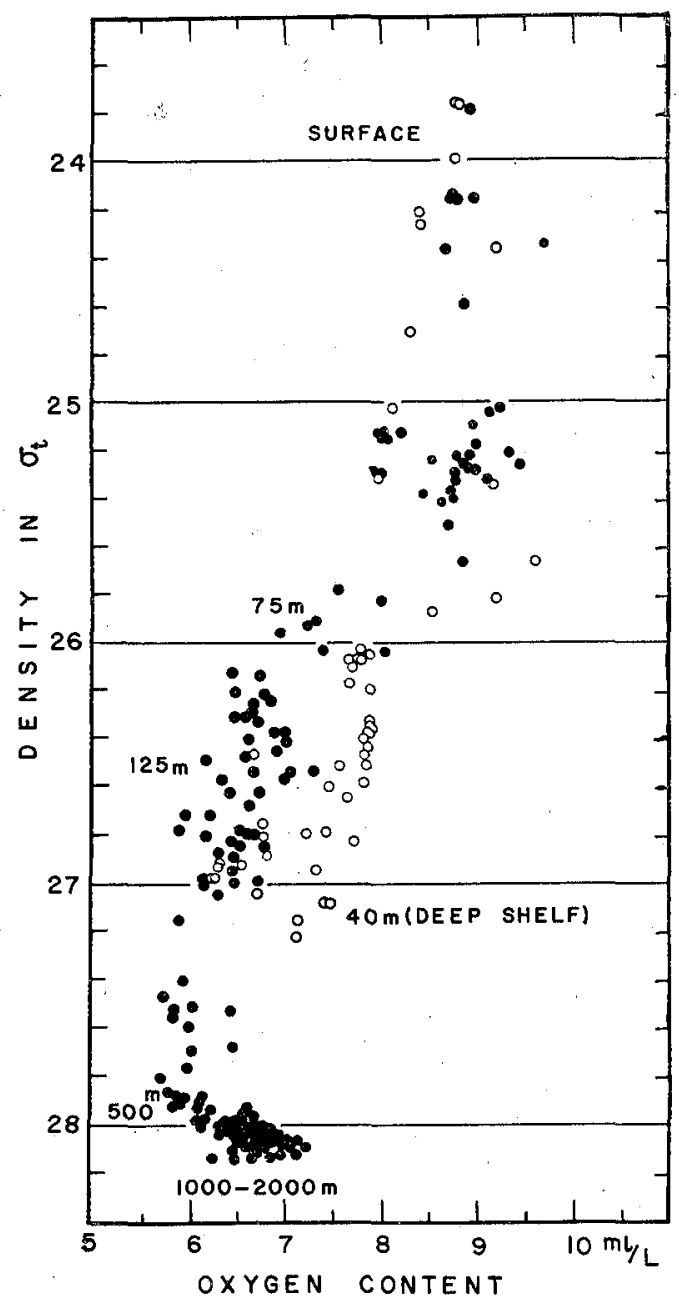

Fig. 17. Density $\left(\sigma_{t}\right)$-oxygen relationship from data obtained at $\mathrm{T}-3$.

content of very bottom water in the southern Beaufort Sea may not differ greatly from $6.5 \mathrm{ml} / 1$. This may lead to postulate that the Arctic Bottom Water formed in the Norwegian Sea moves in a fairly large rate and the consumption rate of oxygen in deep layers is far less than that in the other oceans.

Fig. 18 presents the plots of temperature-oxygen relationship. The graphs shown in Figs. 17 and 18 are convenient for use in analyzing the water masses and movement of waters in subsurface layers. The surface water is always rich in oxygen with an amount of more than $8 \mathrm{ml} / 1$. The oxygen content of the very bottom water deeper than 2000 meters may be estimated on Figs. 17 and 18, that is, the value of $6.5 \mathrm{ml} / 1$ may be reasonable. In Fig. 18 three water masses are indicated: the Arctic Surface Water, the Deep Shelf Water, and the Atlantic Water. 


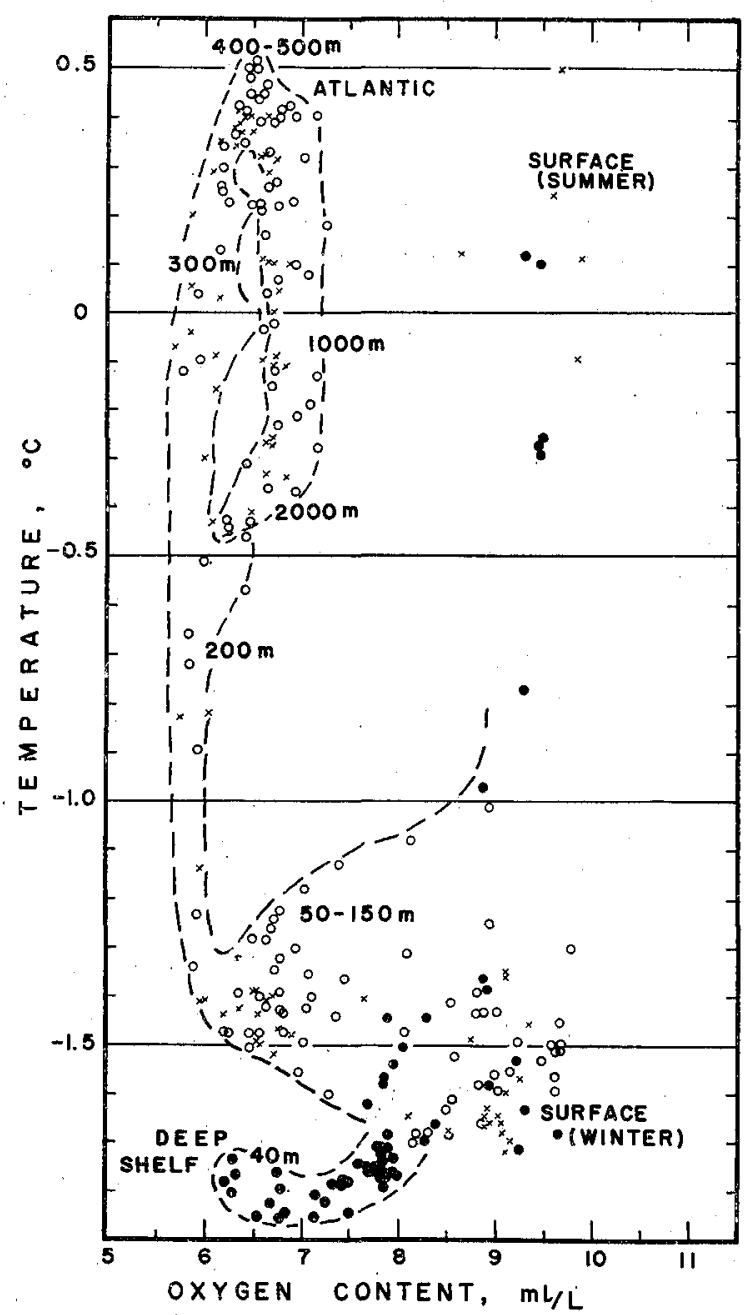

Fig. 18. Temperature-oxygen relationship for stations at $T-3$. Crosses: Sts. 4-10 (Summer). Open circles: Sts. 11-18 (winter). Closed circles: Sts. 20-35 (on the shelf).

Silicate-Silicon

The vertical distribution of silicate-Si is illustrated in Fig. 19, in which the data taken on the shallow shelf are included. In the oceans in middle latitudes the amount of silicon increases down to the bottom, which fact is ascribed to the dissolving of soluble silicates. In the deep waters of the Pacific and the Antarctic the value below 1000 meters was more than $140 \mathrm{\mu g}$-atoms/l (SVERDRUP et al 1942). Low values at the surface layer may reasonably be attributed to the depletion of the silicon due to biological activity and the sinking of organisms or of their skeletal remains. The pronounced maximum of about $25 \mu \mathrm{g}$-at $/ \mathrm{l}$ at about 150 meters will indicate the 


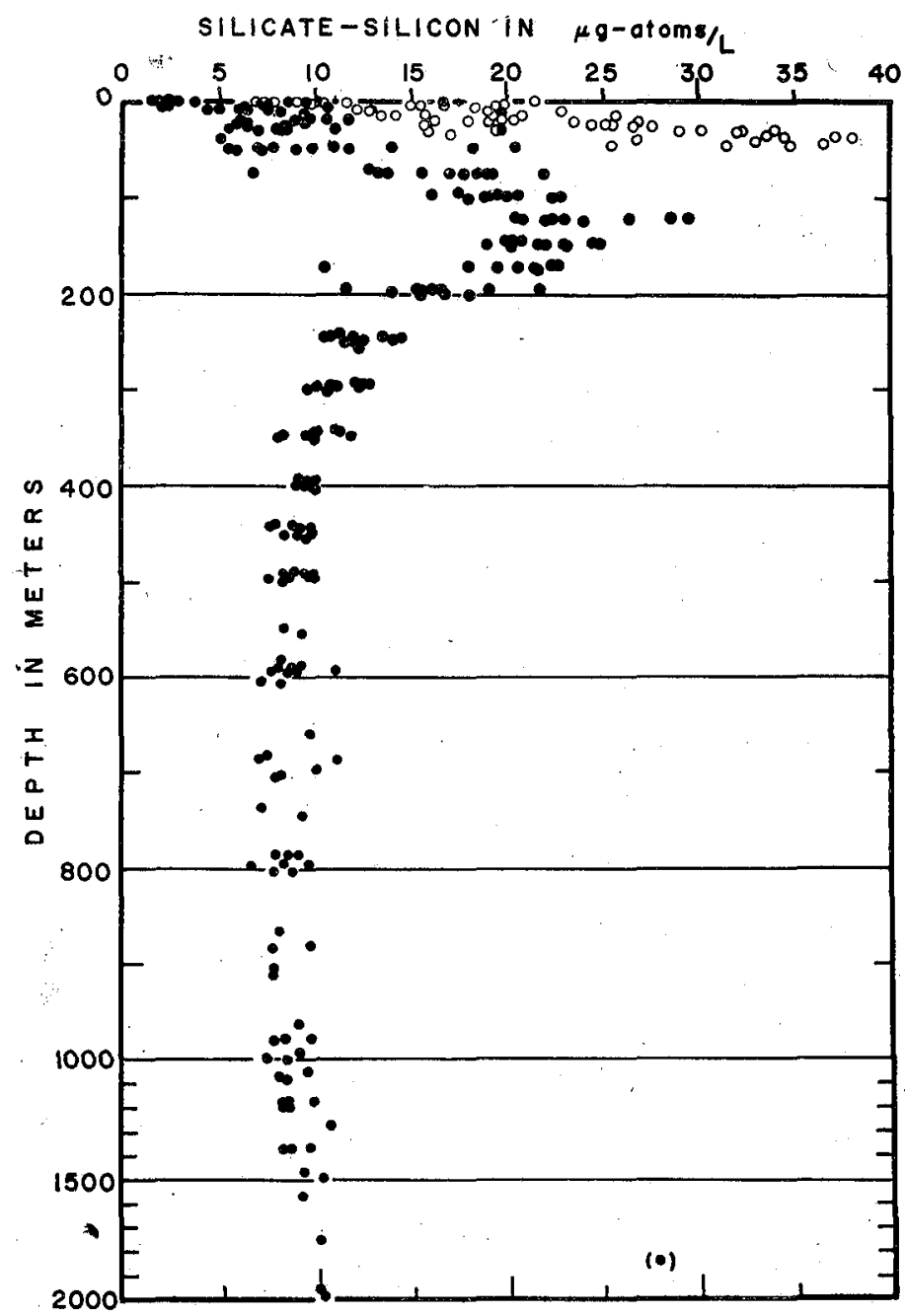

Fig. 19. Vertical distribution of silicate-silicon ( $\mu \mathrm{g}$-atoms/l) observed at $\mathrm{T}-3$ in 1959-1960. Open circles indicate the values at Sts. 20-35.

re-solution of silicon from skeletal material. The remarkable pycnocline to the depth of 200 meters seems to have a very close relation to the re-solution of silicon from sinking skeletal remains. Another explanation on the occurrence of silicon maxima at 150 meters is that the horizontal transport of silicon-rich water is taking place, that is, the penetration of Pacific water into the Arctic Ocean. It is to be noted that the silicon content at the stations taken on the shelf was considerably high (open circles in Fig. 19).

A minor minimum of less than $10 \mu \mathrm{g}$-at $/ 1$ seems to exist at about 800 meters, 
which corresponds to a minor maximum in oxygen content. A gradual increase towards the Lottom is to be recognized in Fig. 19. An exceptionally large value of $28 \mathrm{gg}$-at/l at about 1840 meters resulfed from the fact that the sampled water contained kottom mud. Prokably the silicon content of the very bottom water in the Pacific side of the Arctic will be found not to exceed $20 \mu \mathrm{g}$-at $/ \mathrm{l}$.

The silicon content in the section through St. 5 to 17 is presented in Fig. 20. The vertical distritution of silicon at exch staticn will be recognized in Figs. $6 \mathrm{a}, \mathrm{c}$, $d$, and $e$. The content in the upper layers increased with the advance of winter

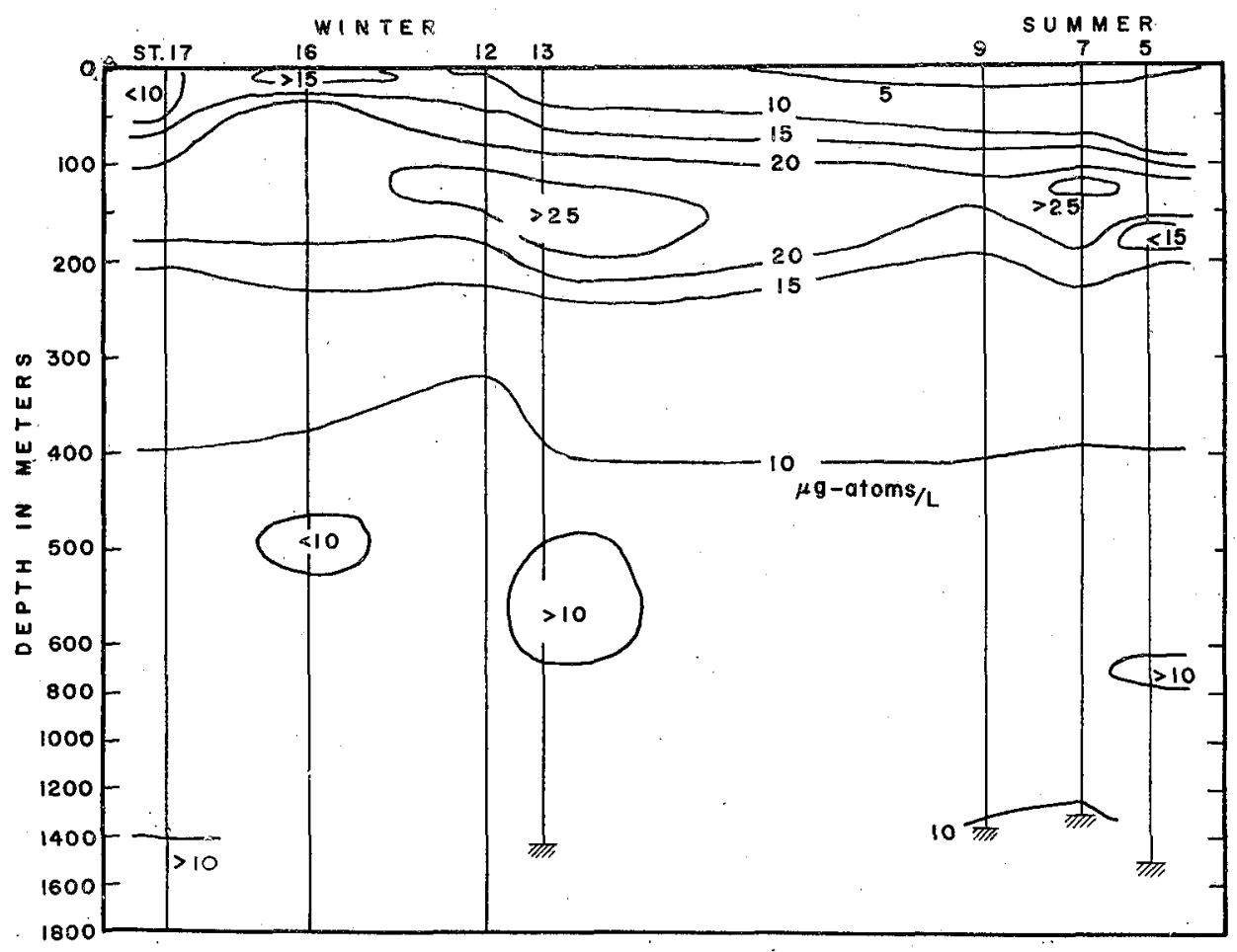

Fig. 20. Distribution of silicate-silicon $(\mu g$-atoms/1) in a vertical section between St. 5 and St. 17 at T-3.

season; the highest values occurred during the mid-winter. This seasonal change is just opposite to the annual cycle in the oxygen content. The annual cycle in the silicon observed at $\mathrm{T}-3$ is in accord with the observations at middle latitudes.

Figure 21 exhibits a typical example of annual variation in silicon in the shallow waters. On account of the utilization of silicon by organisms in the euphotic layer, depletion of the silicon was observed in the mid-summer. The content of more than $15 \mu \mathrm{g}-a \mathrm{t} / 1$ at the surface of $\mathrm{St} .28$ was observed in the middle of the summer. This may te ascribed to the horizontal transport of silicon-rich waters from other sources, perhaps the river waters. Another conjecture on this point is the silicon-rich discharges 


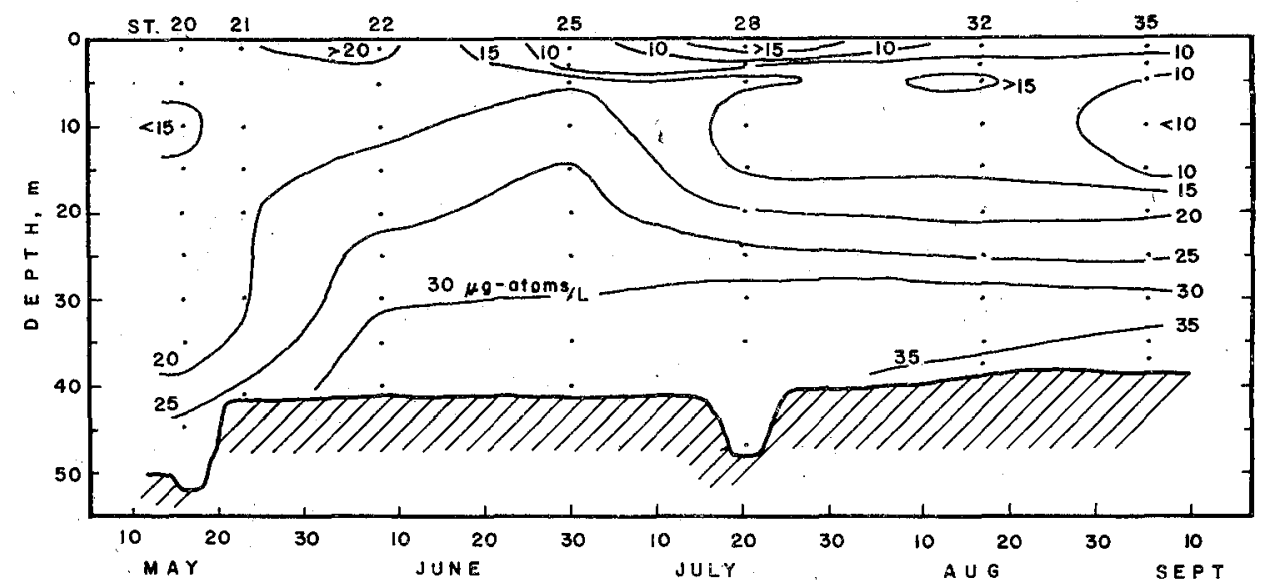

Fig. 21. Vertical distribution of silicate-silicon ( $\mu$ g-atoms/1) in a vertical section between St. 20 and St. 35 at $\mathrm{T}-3$.

from $\mathrm{T}-3$. The covering of dirt on $\mathrm{T}-3$ is drained off during the ablation season, but the amount of silicon dissolved into the drainage may be far less than that of river water. Also the short ablation season of about two months does not give an ample time for the re-solution of silicon from dirt. The conjecture is associated with the position of the station. Actually the island moved east after the second grounding (see Fig. 4d). Consequently the high silicon content at St. 28 may be ascribed to the advected water and to the difference in the position of station. As the stations are located in the vicinity of the Alaskan coast, the effect of the discharges from the rivers and land seems to exist. The silicon content in the subsurface layers at Sts. 20-35 was more than $20 \mu \mathrm{g}$-at $/ 1$, as has already been illustrated in Fig. 19 and Fig. 21 . It was reported that the maximum inflow of Pacific water takes place in the summer. The locations of Sts. 20-35 are not very far from the Bering Strait. Hence the relatively silicon-rich Pacific water with the river waters, largely from the Yukon River, will quite likely have penetrated to the localities of $T-3$ stations on the continental shelf.

The amounts of silicon at Sts. 20 and 21 are between 15 and $20 \mu$ g-at/l down to a depth of about 30 meters. This situation will also suggest that the vertical convection during the winter took place to a depth of about 30 meters. With reference to the vertical distribution of silicon at St. 35, the influence of advected water should be considered. As already mentioned, the pack ice which covered Colby Bay broke off at the end of August. The advection of offshore ice-melt water under the influence of wind action is quite possible.

In summarizing the data taken at $\mathrm{T}-3$ since 1957, the vertical distribution of average values in oxygen, silicon, phosphate-phosphorus and nitrate-nitrogen are presented in Fig. 22. The ratios of the ranges of $\mathrm{Si}, \mathrm{N}$, and $\mathrm{P}$ are $12-15: 2-20: 1$. The relation among these elements in regard to the development of plankton and other 


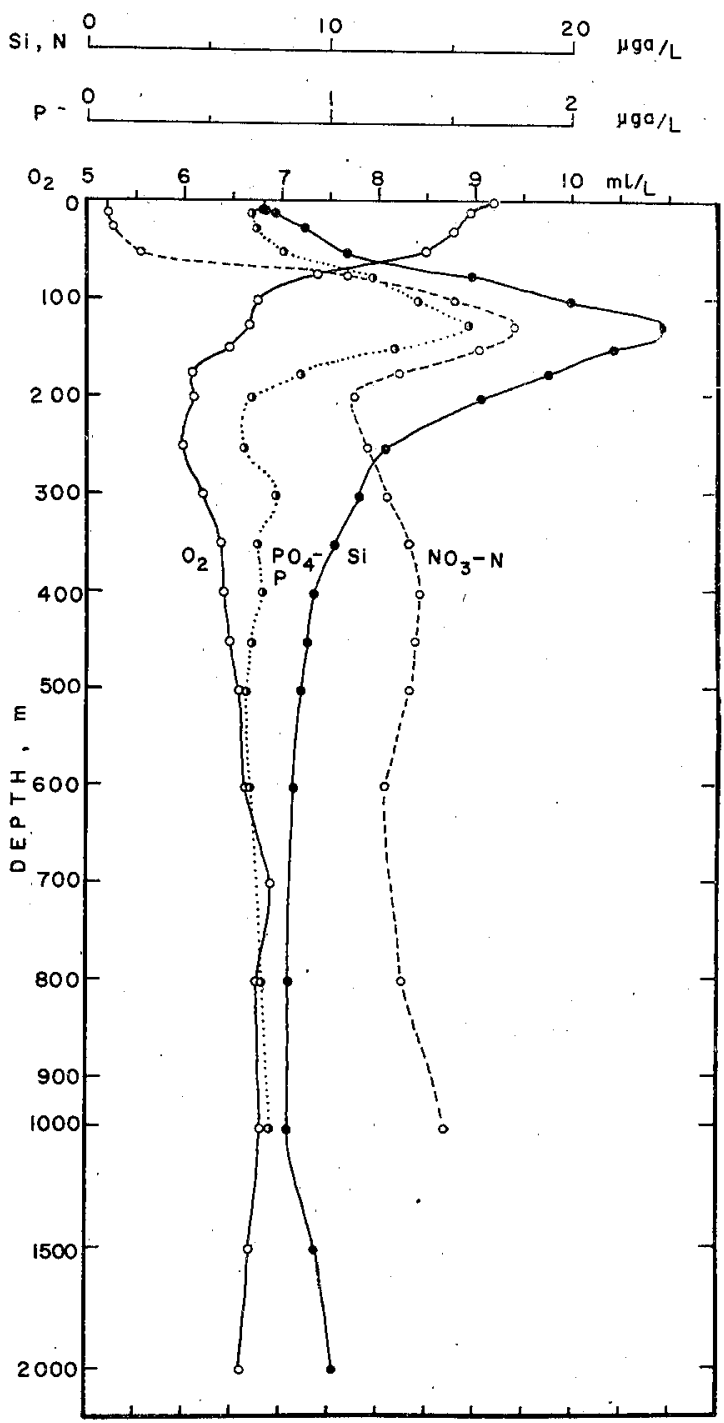

Fig. 22. Vertical distribution of average content of dissolved oxygen, nitrate-N, phosphate- $\mathrm{P}$, and silicate-Si observed at Ice Island $\mathrm{T}-3$.

organisms have been discussed by several researchers (SVERDRUP et al. 1942). It is to be noted that the maxima in phosphate and nitrate occurred as the same depth of 125 meters which depth corresponds to the depth of silicon maximum found at the stations in 1959-1960.

It is to be supplemented that the Russian data from the Atlantic side of the Arctic do not show any marked maxima in silicon, phosphorus, and nitrogen at about 150 
meters, thus no oxygen minimum. This will also suggest the inflow of Pacific water into the Pacific side of Arctic Ocean or the difference in biological activity between the Atlantic and the Pacific side.

In connection with the distribution of silicate-silicon the plots of density-silicon relationship are shown in Fig. 23. The abundance in silicon at Sts. 20-35 will be

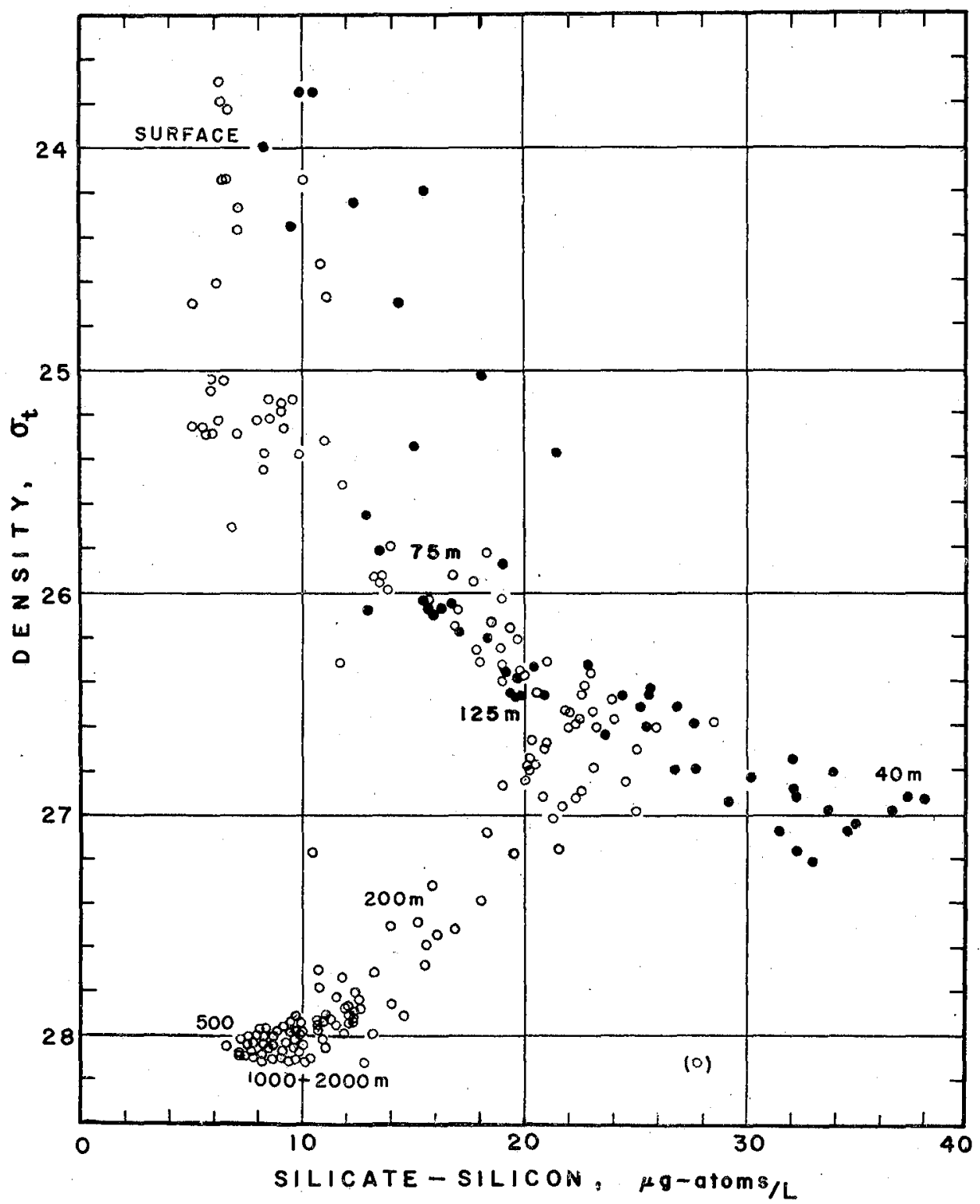

Fig. 23. Density $\left(\sigma_{t}\right)$-silicon relationship for $T-3$ stations.

Closed circles: Sts. 5-18. Open circles: Sts. 20-35. 
interpreted as the results of advection of silicon-rich water from the Pacific and rivers. The waters of the northern Pacific are extrememly rich in silicon, containig amounts comparable to those in the Antarctic waters. If the Pacific waters entered into the Chukchi and Beaufort Seas, a maximum of silicon content should be found at depths of less than 75 meters (average depth of Pacific interlayer). Fig. 23 indicates that the maximum silicon content exists at about 150 meters, where $\sigma_{t}=26.5$. The maximum of silicon content at about 150 meters for off-shore stations as shown in Figs. 19 and 20 is likely associated with the marked pycnocline and vertical mixing. The re-solution of silicon from silicious remains will take place during the settling. If the re-solution rate of silicon is independent of time, an increase of silicon with depth will be observed as shown in Fig. 19, when the settling velocity is retarded by the presence of pycnocline. However the biological productivity at the surface is considered to be very small, so that mixing of silicon-rich Pacific and river water with the Arctic water may contribute to the occurrence of a silicon maximum at about 150 meters.

Fig. 23 indicates the presence of at least four different water masses: the surface water (less than $10 \mu \mathrm{g}$-at $/ \mathrm{l}$ in $\mathrm{Si}$ ), silicon rich off-shore water $\left(\mathrm{Si}=25 \mu \mathrm{g}\right.$-at $\left./ 1, \sigma_{t}=26.5\right)$, silicon rich water on the shelf $\left(\mathrm{Si}=35 \mu \mathrm{g}\right.$-at $/ 1, \sigma_{t}=27.0$ ), and the deep water (about 10 $\mu g$-at/l). Detailed analysis of these water masses will be given in the following.

\section{Water masses in the Arctic Ocean}

Three main water masses have been identified in the Arctic Ocean: the Arctic Surface Water, the Atlantic Water, and the Arctic Bottom Water. The Arctic Surface Water has a low chlorinity ranging from a few per mille to about $18 \%$, particularly in the late summer it becomes nearly fresh. The temperature of this water remains at freezing point even in the summer. In the above chapter on the distribution of temperature, the occurrence of top layer with a temperature of about $0^{\circ} \mathrm{C}$ was reported.

The Atlantic Water is characterized by a positive temperature and a relatively high chlorinity of about $19.3 \%$. Several authors have reported that the Atlantic Water enters the Arctic Ocean north of Svalbard as a subsurface flow at depths between 100 and 1000 meters. This water spreads gradually towards the Pacific side, during which process decrease in temperature and chlorinity has been observed as a result of admixture with the Arctic Surface Water and the Arctic Bottom Water.

The deep water of the Arctic Basin has a uniform chlorinity of about $19.36 \%$ and the minimum temperature of $-0.8^{\circ} \mathrm{C}$ at about 2500 meters in the Atlantic side, and $-0.4^{\circ} \mathrm{C}$ at 2000 meters in the Pacific side (see Table 4) Below these levels the temperature increases in a rate of adiabatic heating.

In the present paper, the term "water mass" is to be used in a broad meaning, that is, some of water masses are local and may be only transient. The water masses defined here may vary to some extent from year to year and may disappear in some certain season of the year. The classification of deep-sea water masses of HellandHansen and Sverdrup may be applicable to the Atlantic Water and the Arctic Bottom 
Water, particularly to the bottom water (SVERDRuP et al 1942).

In order to identify the water masses defined here the plots of temperature and corresponding chlorinity (T-Cl or T-S diagram) provide a convenient means. The plots of various chemical elements against temperature, chlorinity and other properties also give auxiliary assistance in the analysis of water masses. These diagrams shown above have suggested the existence of some water masses.

The T-Cl relationship for the areas covered by the drift of T-3 in 1959-1960 is illustrated in Fig. 24. The water at the surface, usually between 0 and 10 meters, is warmed in summer and extensively desalinified. Therefore, plots of these values with less than $17 \%$ in chlorinity were omitted in preparing Fig. 24 . The values at the

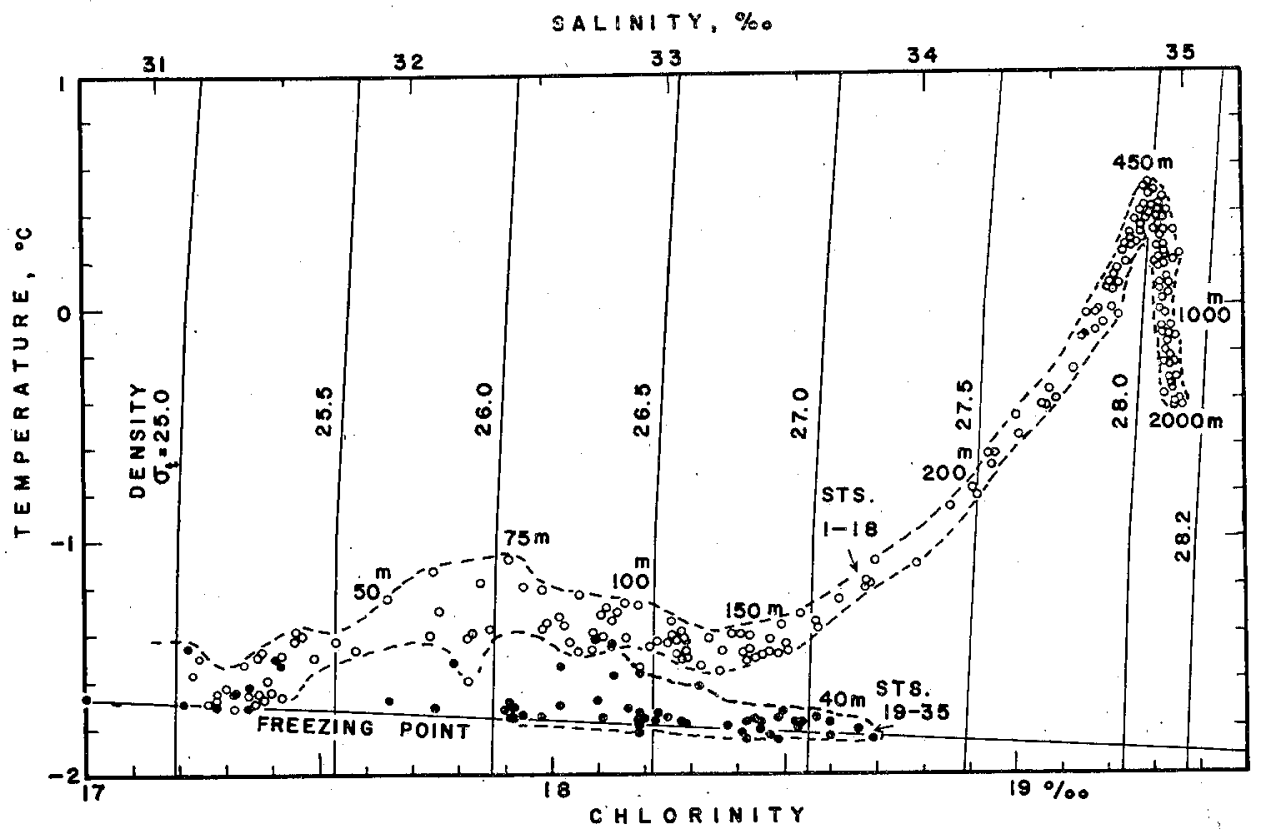

Fig. 24. Temperature-chlorinity diagram for stations at $T-3$ in 1959-1960. Open circles indicate the values at Sts. 19-35, small dots represent the values at Sts. 1-18.

stations occupied on the shelf, shown in closed circles, will undoubtedly suggest the existence of a water mass with relatively low temperature and high chlorinity as compared with the water at a level of 50 meters at off-shore stations. As the waters at surface layers are highly diluted, the values for these waters on the shelf are also not plotted in the diagram. The water found on the shelf is likely to correspond to the Deep Shelf Water or the Modified Deep Shelf Water identified by SAUER et al (1954) and LAFOND (1954).

The water at less than 150 meters has a chlorinity of less than $18.5 \%$ and relatively low temperature. This may be included in the Arctic Surface Water in a broad sense: 
The waters found at about 75 meters, designated here as the "Pacfic Upper Intermediate Water", is of interest for a detailed analysis.

The Atlantic Water is characterized by positive temperatures, having a maximum of $0.42^{\circ} \mathrm{C}$ in summer stations and $0.45^{\circ} \mathrm{C}$ in winter stations at $\mathrm{T}-3$ (Table 2 ). The maxima of temperature occurred at 450 meters in average, where the chlorinity was almost $19.30 \%$. The Atlantic Water observed at $\mathrm{T}-3$, occupying the depths between 250 and 900 meters, is indicated by the upper and lower $0^{\circ} \mathrm{C}$ isotherms. The core of the Atlantic Water existed on the isopycnal surface of 28.0.

It has been reported that the Arctic Bottom Water occurring in the Atlantic side has a uniform chlorinity of about $19.36 \%$ and a minimum temperature of $-0.8^{\circ} \mathrm{C}$ at about 2500 meters. In contrast to this, the deep water in the Pacific side has a relatively high temperature of about $-0.4^{\circ} \mathrm{C}$, in so far as the present observations on $\mathrm{T}-3$ are concerned. And the data collected in other localities in the Pacific side showed similar temperature structure. The chlorinity was $19.36 \%$ in the most part of the Pacific side, thus there was about 28.10 density. In discussing the potential temperatures of deep water, the effective sill depth of 1300 meters on the Lomonosov Range was estimated. This suggests that in the Pacific side the Arctic Bottom Water should be interpreted as the Lower Intermediate Water or transitional water between the warm Atlantic Water and the proper Arctic Bottom Water occupying the Nansen Deep of the Atlantic side. The Lomonosov Range is, of course, the obstruction to the penetration of the Arctic Bottom Water into the Beaufort Deep.

The origin of the Arctic Bottom Water was discussed by Nansen and others; the homogeneous and dense water is formed in the Norwegian Sea due to the complete overturning of water column cooled at the surface. However the recent observations in the Norwegian Sea in the winter season showed that there was no evidence of such overturning as a result from surface cooling (METCALF 1955). It was suggested that a flow of saline (above $35.00 \%$ in salinity or $\mathrm{Cl}=19.38 \%$ ) North Atlantic surface water is taking place along the isopycnal surface of 28.1 and also a very slight downward movement with an angle of inclination of $0.6^{\circ}$ from the horizontal.

The Pacific Upper Intermediate Water characterized by a relatively higher temperature at a level of about 75 meters is next to be discussed. The data taken at T-3 showed that this water persisted on an isopycnal of 26.0. In order to examine the presence of this water in other localities of the Pacific side, the $\mathrm{T}-\mathrm{Cl}$ relations based on the oceanographic data taken by Project Skijump, SP-2, and T-3 in 1957-1958 are plotted in Fig. 25. In this figure the envelopes of the plots of $\mathrm{T}-\mathrm{Cl}$ relationship are represented. The presence of the Pacific Upper Intermediate Water is evidently illustrated at the stations of SP-2 and Project Skijump (see also Table 1). As mentioned earlier, the presence of relatively warm Pacific Upper Intermediate Water was obscure at the stations of T-3 during the I. G. Y. Fig. 25 also indicates supercooling of surface water at the stations occupied at $\mathrm{T}-3$ in $1957-1958$, being supercooled $0.2^{\circ} \mathrm{C}$ in its maximum. 


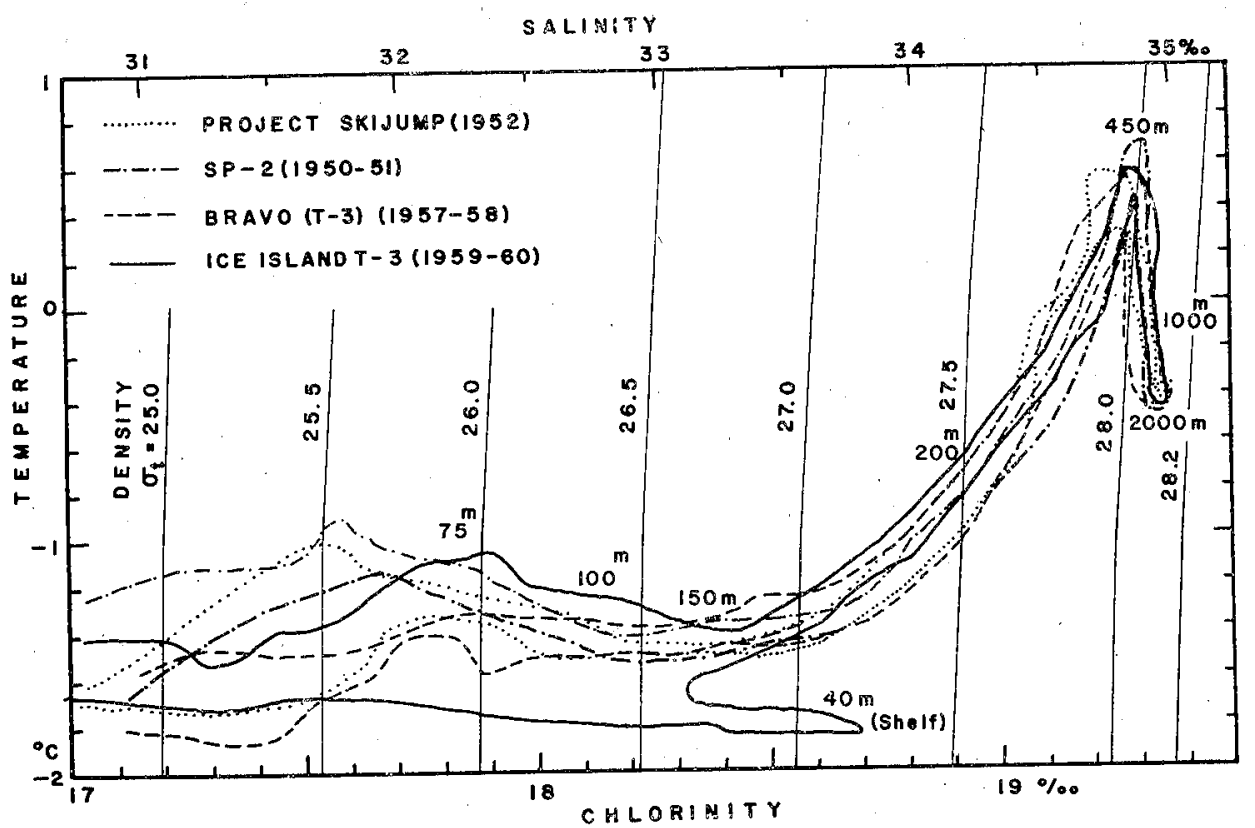

Fig. 25. Temperature-chlorinity diagram for the stations from $\mathrm{T}-3, \mathrm{SP}-2$, and Project Skijump.

The waters in subsurface layers shown in Fig. 25 showed no remarkable difference according to the locality of stations. Data on the waters on the shallow shelf are also illustrated in this figure. According to LAFOND (1954), this water should be called Deep Shelf Water, being characterized by a temperature of $-1.1^{\circ} \mathrm{C}$ and chlorinity of 17.4-18.3\%, thus $\sigma_{t}=25.4$ to 26.6. At the present observations on $\mathrm{T}-3$ the Deep Shelf Water appeared with high values in chlorinity, up to $18.7 \%\left(\sigma_{t}=27.2\right)$. This discrepancy may be attributed to the difference in the location of stations. It should be remarked that the observational data analyzed by LAFOND and others were collected in the midsummer cruises in the southern Chukchi, Beaufort and Bering Seas. In addition to the Deep Shelf Water, the following water masses were identified by LAFOND (1954); Alaskan Coastal Water, North Siberian Coastal Water, Ice Melt Water, Modified Ice Melt Water, Intermediate Water, Modified Shelf Water and the Arctic Basin Water. The values of temperature, chlorinity and corresponding desnity of these water masses are shown in Table 8.

The temperatures of water masses shown in Table 8 are evidently high, because the oceanographic stations were occupied in mid-summer. It is certain that some of these water masses might be modified or even quite lacking in the winter season when vertical convection takes place intensively. The basic water masses among these are the Alaskan Coastal Water, North Siberian Coastal Water, Ice Melt Water and Deep Shelf Water. 
Table 8. Characteristics of water masses in the seas to the west and north of Alaska

(After LAFOND and others, with supplementary data obtained at T-3)

\begin{tabular}{lccc}
\hline $\begin{array}{c}\text { Nomenclature of } \\
\text { water masses }\end{array}$ & $\begin{array}{c}\text { Temperature } \\
\text { in }{ }^{\circ} \mathrm{C}\end{array}$ & $\begin{array}{c}\text { Chlorinity } \\
\text { in } \%\end{array}$ & Sigma- $t$ \\
\hline Alaskan Coastal Water & $7.8-10$ & $11.1-16.6$ & $10-23.4$ \\
Intermediate Water & $4.4-7.2$ & $16.9-17.7$ & $23.8-25.5$ \\
North Siberian Coastal Water & $3.3-6.1$ & $14.4-16.3$ & $20.4-23.5$ \\
Modified Ice Melt Water & 3.3 & 16.6 & 24.0 \\
Modified Deep Shelf water & $1.1-4.4$ & $17.7-18.3$ & $25.4-26.5$ \\
Ice Melt Water & $>-1.1$ & $15.9-16.9$ & $23.0-24.5$ \\
Deep Shelf Water & $<-1.1$ & $17.4-18.3$ & $25.4-26.6$ \\
\hline
\end{tabular}

The Alaskan Coastal Water originates from the Pacific Ocean and is highly diluted by the discharge from the land; the Yukon River is the main source of fresh water supply in the western coast of Alaska. The North Siberian Coastal Water water has low chlorinity due to river discharges along the Siberian coast. The Ice Melt Water is evidently the very diluted surface water due to the melt of ice and snow. This water disapperas in the course of ice formation. Among these basic water masses modification is continually taking place.

The Intermediate Water indicated in Table 8 should not be confused with the previously designated Pacific Upper Intermediate Water. The former appears transiently on the shallow continental shelf in the southern Chukchi and Beaufort Seas. The latter refers to the warm interlayer found at a level of 75 meters. In connection with the Upper Intermediate Water the $\mathrm{T}-\mathrm{Cl}$ relationship was already given in Figs. 24 and 25.

Three water masses among the ones indicated in Table 8 are to be encountered. at offshore stations of T-3; the Ice Melt Water, the Modified Deep Shelf Water, and the Deep Shelf Water. These water masses are found in the upper layers of less than 150 meters at T-3 stations. The Modified Deep Shelf Water should, at present, be included in the summer-heated Upper Intermediate Water. It is pointed out that the Deep Shelf Water observed at T-3 has a relatively higher chlorinity than the one indicated in Table 8.

It is to be remarked that relatively cold water was found in the lower part of the halocline zone between 100 and 200 meters at the stations taken at T-3 in 19591960. This is to be recognized in Figs. 5 (vertical temperature distribution) and $6 \mathrm{a}$, $b, c$ (vertical profiles of temperature and chlorinity). In examining the data taken at T -3 since 1952, the presence of this "Cold Interlayer" is more pronounced at the stations in the region north of Ellesmere Island. The oceanographical elements of Cold Interlayer are presented in Table 9. 
Table 9. Characteristics of Cold Interlayer observed at Ice Island T-3

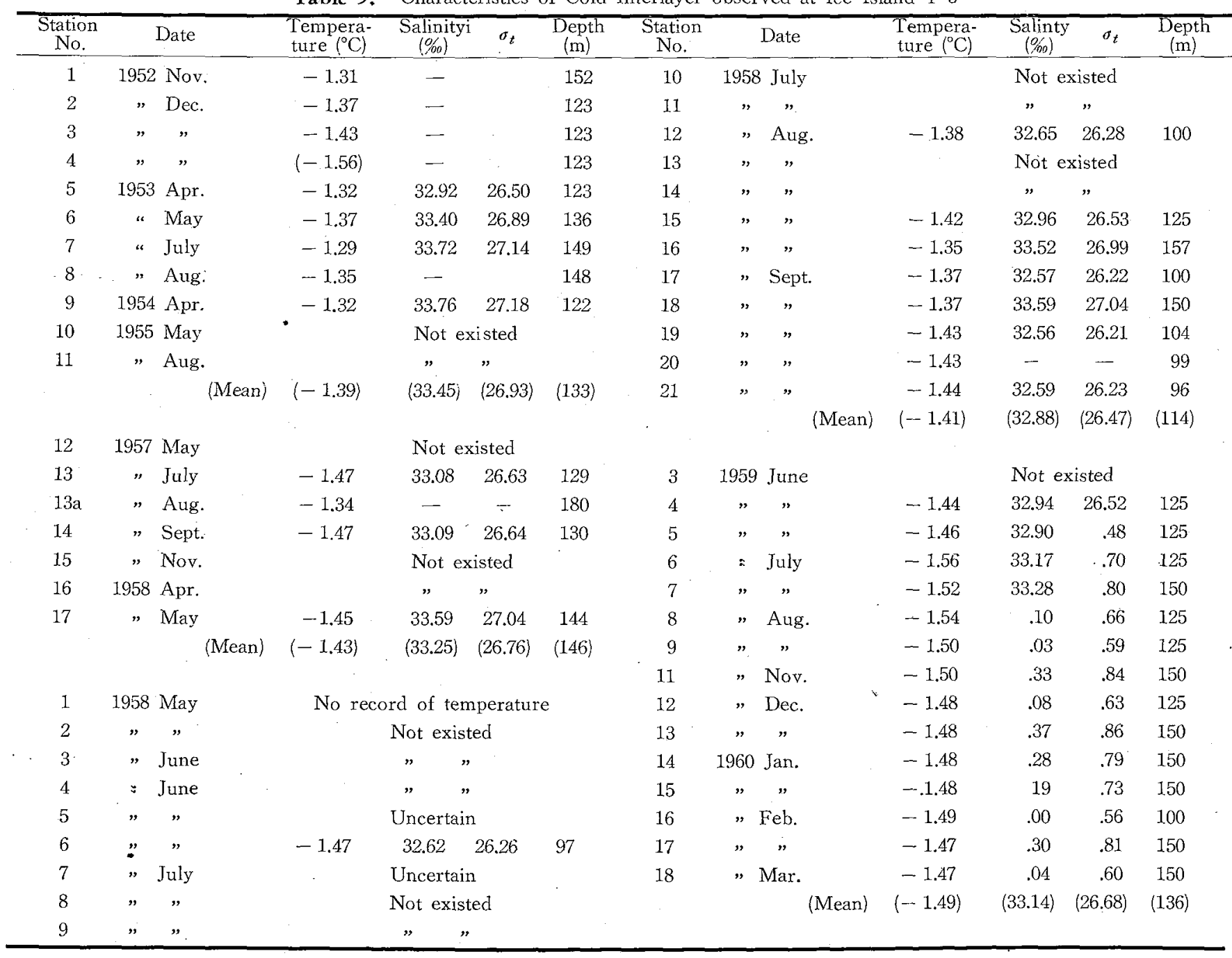


The Cold Interlayer was observed not only at stations of $\mathrm{T}-3$, but also at stations of SP- 2 and Project Skijump as shown in Fig. 25. Very cold environment in the region north of Ellesmere Island may be favorable to the formation of Cold Interlayer. As there exists a large anticyclonic eddy in the Beaufort Sea, this Cold Interlayer may drawn into this eddy when flowing southward along the Canadian Archipelago.

In Table 9 the presence of Cold Interlayer was less pronounced at stations occupied during the summer of 1958 . It is also to be noted that the mean temperature of $-1.49^{\circ} \mathrm{C}$, lower than that in $1952-1955$ off the Ellesmere Island, was obtained at stations taken in 1959-1960 in the southern Beaufort Sea. These seem to be contradictory to postulate that the northern region of Ellesmere Land is the birthplace of Cold Interlayer. It should however be pointed out that the winter temperature changes year to year and that the western costal region along the Canadian Archipelago may be the secondary source of cold water formation. In order to affirm the postulated origin of Cold Interlayer and to give an explanation of the mechanism of its persistency, future observations in this region are indispensable.

With reference to the origin and movement of the water masses in the Arctic Ocean, the plots of $\mathrm{T}-\mathrm{Cl}$ relation for the stations to the north of Bering Strait and some stations in the Atlantic side are introduced in Fig. $26 \mathrm{a}, \mathrm{b}$. Envelopes of $\mathrm{T}-\mathrm{Cl}$

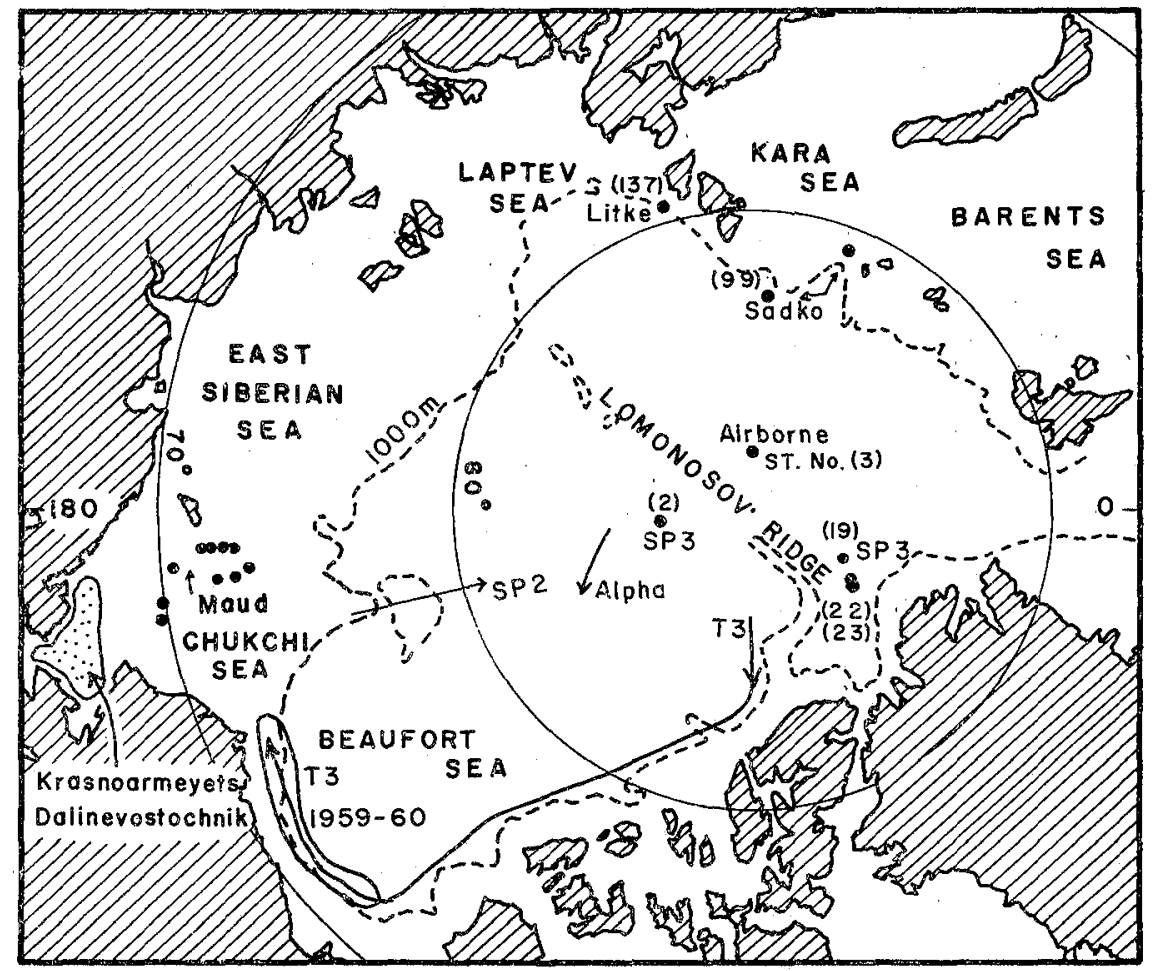

Fig. 26 a. Locations of stations in compiling Fig. 26 b. 


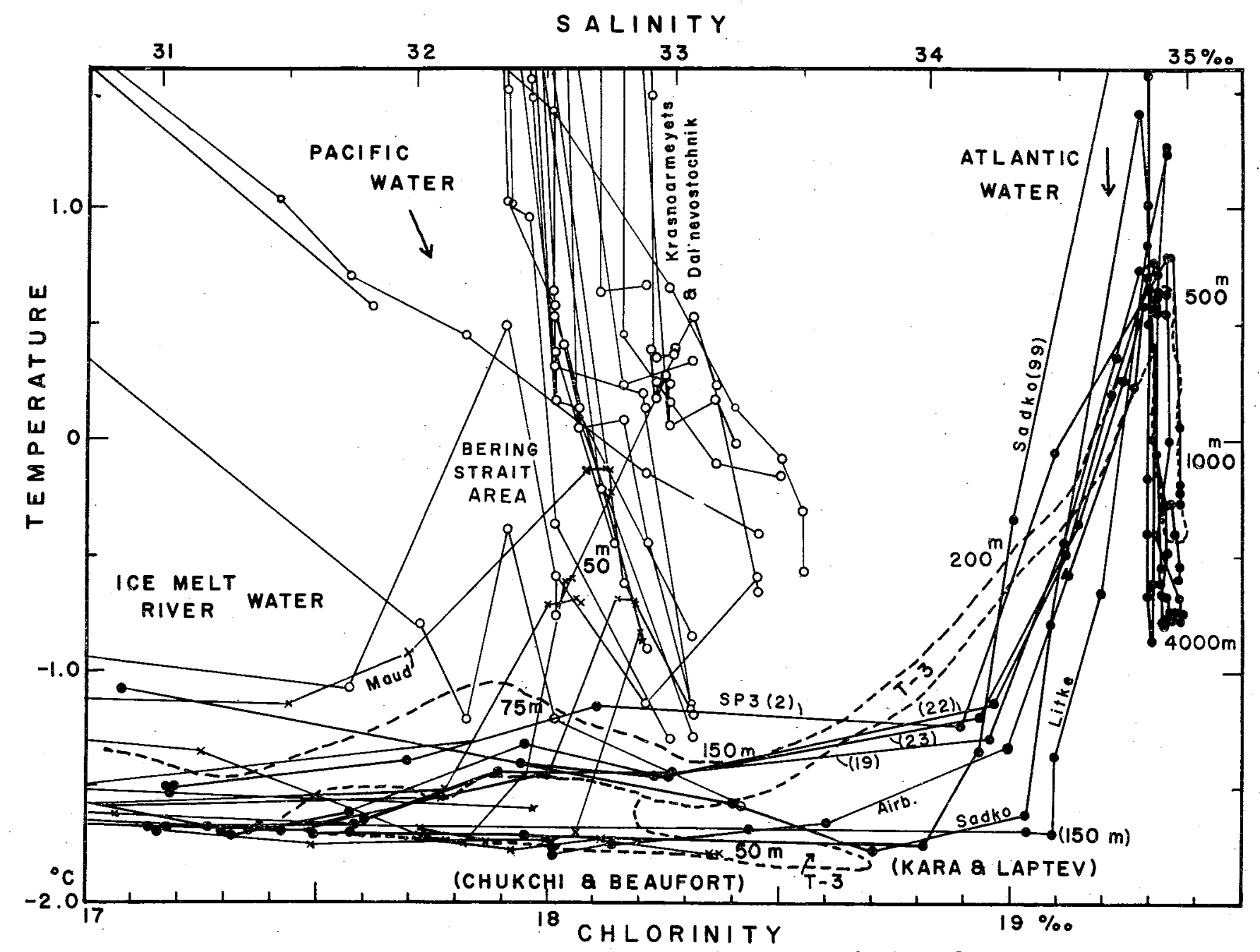

Fig. 26 b. Temperature-chlorinity diagram for the stations in the Arctic Ocean

Crosses: Maud, Open circles: Krasnoarmeyets and Dal'nevostochnik,

Closed circles: Russian stations shown in Table 10 and Fig. 26 a. 
plots for T-3 stations are also indicated in Fig. 26 b. The data sources in compiling Fig. 26 b. are tabulated in Table 10.

Table 10. List of stations in compiling Fig. $26 \mathrm{~b}$ (T-Cl diagram)

\begin{tabular}{|c|c|c|c|}
\hline $\begin{array}{c}\text { Name of Vessel } \\
\text { or } \\
\text { Experdition }\end{array}$ & Year & $\begin{array}{l}\text { Station } \\
\text { No. }\end{array}$ & Locality \\
\hline Maud & 1952 & $1-11$ & Southern Chukchi Sea \\
\hline Dal'nevostochnik & 1932 & $31-34$ & $"$ \\
\hline Krasnoarmeyets & 1933 & $39-58$ & $"$ \\
\hline Sadko & 1935 & 99 & $82^{\circ} 51^{\prime} \mathrm{N}, 87^{\circ} 03^{\prime} \mathrm{E} \quad$ (Kara Sea) \\
\hline Sadko & 1935 & $*$ & $81^{\circ} 08^{\prime} \mathrm{N}, 69^{\circ} 35^{\prime} \mathrm{E} \quad($ Kara Sea $)$ \\
\hline Litke & 1948 & 137 & $79^{\circ} 24^{\prime} \mathrm{N}, 107^{\circ} 59^{\prime} \mathrm{E}$ (Laptev Sea) \\
\hline $\begin{array}{l}\text { High-Altitude } \\
\text { Airborne Expedition }\end{array}$ & 1949 & 3 & $88^{\circ} 24^{\prime} \mathrm{N}, 90^{\circ} 16^{\prime} \mathrm{E}$ (Nansen Deep) \\
\hline $\mathrm{SP}-3$ & 1954 & 2 & $87^{\circ} 01^{\prime} \mathrm{N}, 170^{\circ} 48^{\prime} \mathrm{W}$ (Makarov Deep) \\
\hline $\mathrm{SP}-3$ & 1955 & 19 & $86^{\circ} 30^{\prime} \mathrm{N}, 27^{\circ} 28^{\prime} \mathrm{W}$ (Off Greenland) \\
\hline $\mathrm{SP}-3$ & 1955 & 22 & $86^{\circ} 07^{\prime} \mathrm{N} ; 34^{\circ} 55^{\prime} \mathrm{W}(\quad, \quad)$ \\
\hline $\mathrm{SP}-3$ & 1955 & 23 & $86^{\circ} 02^{\prime} \mathrm{N}, \quad 36^{\circ} 49^{\prime} \mathrm{W}$ \\
\hline
\end{tabular}

* This information was taken from the paper of Musina (1960).

Station number is unknown.

It should be remarked that the waters with a temperature above $1.6^{\circ} \mathrm{C}$ and chlorinity of less than $17 \%$ are not plotted in Fig. 26. These waters are evidently summer surface water. As mentioned before, the characteristic properties of water masses indicated in Table 8 are deduced from the oceanographic results obtained in the Beaufort, Chukchi, and Bering Seas. Accordingly, the data from the Maud, Dal'nevostochnik, and Krasnoarmeyets are shown as supplementary in Fig. 26 b. The plots of these results show prominently the penetration of Pacific water into the Arctic Ocean, following mainly along isopycnal surfaces of 25.5-26.5. Even in the central part of the Arctic Basin the influence of Pacific water was observed, this was verified at the stations of SP-3 occupied off the northern coast of Greenland. At these stations, not only the temperature data of warm interlayer at about 75 meters, but also the microbiological observation supported this conjecture (KRISS 1955). Recently COACHMAN and BARNES (1961) indicated the penetration of Bering Water into the Arctic Ocean, using the shallow temperature maximum at about 75 meters. They also pointed out that the Deep Shelf Water may originate from the Bering Strait in winter.

The greatest depths of the stations taken in the southern Chukchi Sea shown in Fig. 26 were less than 70 meters. The $\mathrm{T}-\mathrm{Cl}$ relations at these stations indicated that the Pacific Upper Intermediate Water appeared with a relatively high temperature of above $-1.0^{\circ} \mathrm{C}$ at an average depth of 50 meters. The bottom layer of Maud stations showed the presence of the Deep Shelf Water, particularly at the stations in higher 
latitudes. The chlorinity of this water was less than that found at $\mathrm{T}-3$ stations on the shelf. This suggests that the waters on the Siberian Shelf are diluted by the river discharges, and that the Pacific water flows northward along the Alaskan side.

The temperature-chlorinity correlation for the stations distributed in the Atlantic side indicated that a fairly cold water, at approximately the freezing point, occupies the levels between the surface and about 100-150 meters. The stations located in the Kara and Laptev Seas showed that his water was present down to 150 meters (Fig. $26 \mathrm{~b}$ ). This water is presumably formed by the thermohaline circulation due to ice formation. But the stable stratification in density above 100-150 meters will intercept the vertical circulation down to the depths. Actually the mean convection depth of 75 meters was computed in the Atlantic side of the Arctic Ocean (TrMOFEYEV 1960). However the vertical convection will develop in the vicinity of islands, banks, and shoals; along the continental slope the descending flow of surface water, becoming denser due to ice formation, will be found. The cold and saline water at a level of 100-150 meters in the Atlantic side is likely to be formed in severe winter, particularly near the islands and banks. This water should be called the "Atlantic Upper Intermediate Water".

The seasonal change of the vertical distribution of density in the surface layer is illustrated in Fig. 27. This figure indicates that the depth of mixing due to thermohaline circulation may be restricted within the levels above 20-30 meters, on some

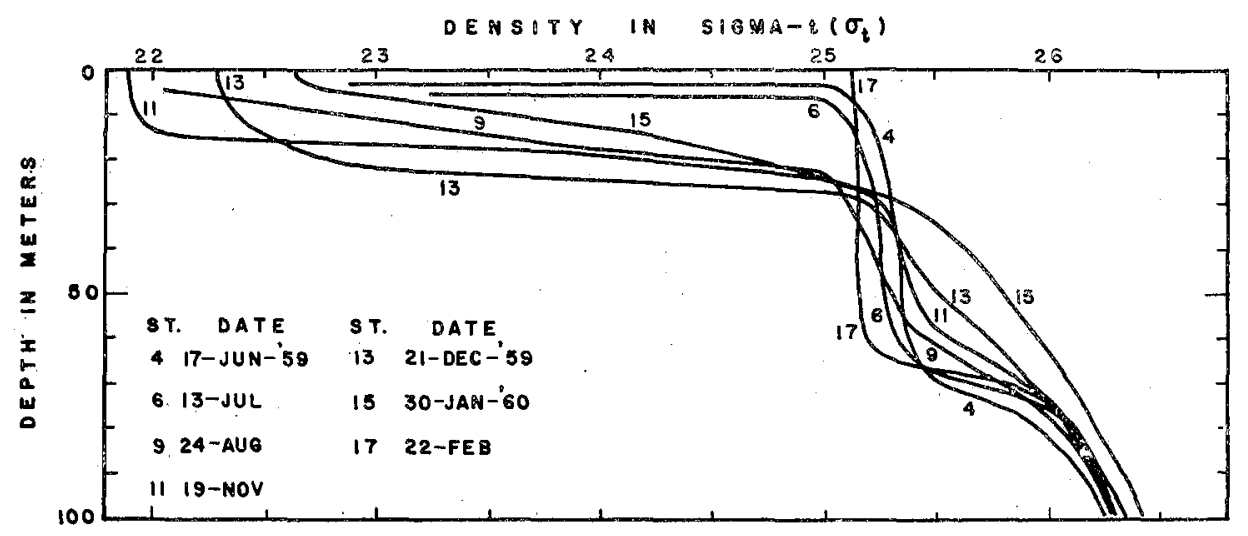

Fig. 27. Annual variation in density $\left(\sigma_{t}\right)$ in the upper layer $(0-100 \mathrm{~m})$ observed at the Ice Island T-3.

occasions the depth will exceed this horizon. However it was reported that the depth of convection was less than 25 meters in the southern Beaufort Sea, assuming a reasonable heat loss of $20 \mathrm{~kg} . \mathrm{cal} / \mathrm{cm}^{2}$ for the ice potential computation (CORTON 1955). Those accounts will be interpreted to mean that the remnant of warmed surface water should be mixed well within this convection layer of 20-30 meters thick. In correspondence to this convective circulation the thickness of winter ice will be estimated by the following simple equation (ZUBOV 1945): 


$$
i=\frac{1.1 z \Delta S}{S_{w}-S_{i}},
$$

where $i$ is the thickness of ice, $z$ the depth of convection, $\Delta S$ the increase in chlorinity (or salinity) due to ice formation, $S_{w}$ the chlorinity sea water at the initiation of ice formation, $S_{i}$ the chlorinity of sea ice.

In order to evaluate the chlorinity increase due to ice formation, the plots of chlorinity and corresponding temperature at a level of 30 meters are shown in Fig. 28. From Fig. 28 the chlorinity of sea water before the ice formation was taken as

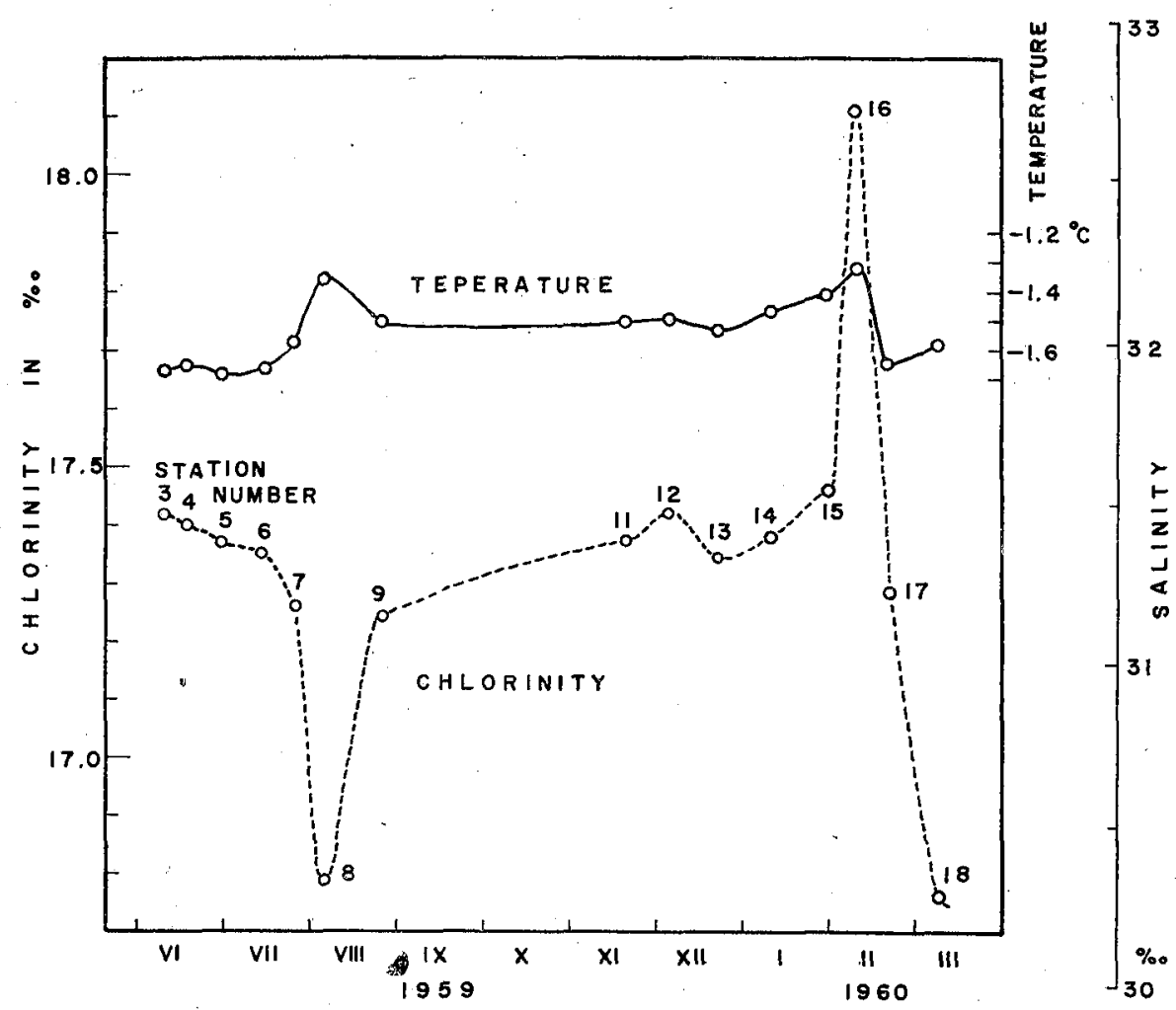

Fig. 28. Seasonal variation of chlorinity and temperature at 30 meters (Ice Island $\mathrm{T}-3$ ).

16.8\% and, after ice formation 17.4\%. An abrupt change in chlorinity at St. 16 has already been mentioned; the vertical mixing took place intensively during and after blizzard. The chlorinity or salinity of sea ice varies both in time and space (KUSUNOKI $1955 \mathrm{~b})$. In considering the chlorinity observations hitherto made in the Arctic and other seas, a value of $2 \%$ was adopted as the average chlorinity of winter ice. Accordingly the winter ice with a thickness of 1.3 meters should be formed with respect to the vertical convection to a depth of 30 meters. It has been reported that the thickness of winter ice in the southern Beaufort Sea is in the range of 1-2 meters. 
If the depth of vertical convection is 60 meters, the thickness of winter ice should be 2.6 meters which exceeds the average actual thickness in this region. Therefore, the reversal of summer heated surface water into the depth of more than 50 meters may not actually happen. That penetration of Pacific water, the Pacific Upper Intermediate Water, into the Arctic Ocean under the thermohaline convective layer becomes very plausible.

It should be added that the tritium analysis made by GIieTTI and KurP (1959) suggested that the sampled water from the offing of northern Ellesmere Island originated from the southern part of the Chukchi Sea with a mean flow rate of $0.05 \mathrm{~cm} / \mathrm{sec}$ or $14 \mathrm{~km} /$ year. As mentioned before, the temperature profile at the SP-3 stations off Greenland showed a minor maximum at about 75-100 meters. Biological evidence on the presence of Pacific water in the central part was reported by BRODSKIY (1956) who did the hydrobiological work on SP-2. The Upper Intermediate Water of Pacific origin found at about 75 meters depth at the $\mathrm{T}-3$ stations has the following characteristics : temperature $=-1.1$ to $-1.4^{\circ} \mathrm{C}$, chlorinity $=17.5$ to $18.2 \%, \sigma_{t}=26.0 \pm 0.5$.

It has already been stated that a relatively cold and saline water exists at about 100-150 meters in the Kara and Laptev Seas (Fig. 26 b). According to TIMOFEYEv (1960) this water is characterized by a temperature of $-1.75^{\circ} \mathrm{C}$ and salinity $34.60 \%$ (chlorinity $19.15 \%$ ). It is apparent that his type of cold and saline water does not appear in the Pacific side (see Fig. 25). The Deep Shelf Water occurs only on the shallow shelf of the Chukchi and East Siberian Seas. The chlorinity of this water is less than $18.7 \%$. Hence, in the Pacific side of the Arctic in the surface layers of less than 150-200 meters there exist the Arctic Surface Water, the Deep Shelf Water, the Pacific Upper Intermediate Water, and the Cold Interlayer, some of which should be subdivided into transitional and local water masses.

The Atlantic Water with positive temperature is found in the whole of the Arctic Basin, more pronounced in the Atlantic side. At the meridian $0^{\circ}$ the mean temperature of Atlantic Water is about $1.5^{\circ} \mathrm{C}$ within the thickness of 840 meters (between 50 and 900 meters depth), while at the meridian of $180^{\circ} \mathrm{E}$ the temperature decreases to $0.34^{\circ} \mathrm{C}$, within the thickness of 560 meters (TIMOFEYEV 1960). The temperature condition of Atlantic water in the Pacific side was mentioned earlier in the present paper: an average maximum temperature of 0.3 to $0.6^{\circ} \mathrm{C}$, and chlorinity 19.1 to $19.35 \%$. The depth of the upper isotherm of $0^{\circ} \mathrm{C}$ in the Atlantic side is at $50-200$ meters, the lower one at $800-900$ meters. The Atlantic water is characterized by a somewhat hightened oxygen content as compared with the surrounding waters (see Figs. 14 and 22). The oxygen content decreases due to mixing and consumption during the eastward flow to the Pacific side.

The Arctic Bottom Water should be interpreted as a water mass with a minimum temperature of -0.8 to $-0.85^{\circ} \mathrm{C}$ and a uniform chlorinity of 19.32 to $19.39 \%$, being found only in the regions on the Atlantic side below a level of 800-1000 meters. A consideration of the temperature distribution, particularly on the potential tempera- 
ture, leads to the conclusion that the deep water in the Pacific side has a character of transitional type between the Atlantic Water and the proper Arctic Bottom Water in the Atlantic side. The ingress of the cold deep water takes place on the sills of the Lomonosov Range. Consequently, the deep water in the Pacific side should be designated the "Lower Intermediate Water" in contrast to the Upper Intermediate Water.

An account on the mechanism of the formation of deep water was given in the foregoing chapter, discussing the potential temperatures of very bottom waters in the Pacific side and the oceanographic conditions of the Norwegian. Sea. It was noted, there, that the convective mixing and vertical circulation would play a considerable part in the formation of bottom water; the surface waters, becoming denser due to ice formation, descend along the bottom slope. This explanation was emphasized by some Russian researchers (GORDIYENKO and LAKTIONOV 1960). However, so far as the $\mathrm{T}-\mathrm{Cl}$ relations shown in Fig. $26 \mathrm{~b}$ are concerned, there is no evidence to support their conjecture. ZUBOV (1945) stated that the creep-up of warm Atlantic Water along the regions on the continental slope is taking place, particularly through the submarine valleys in the Barents, Kara, and Laptev Seas the creep-up is pronounced. This situation does not give a favor of occurrence of vertical convection down to the very bottom of the Arctic Basin. It is evident that the markedly large gradient in density in the surface layers less than 300 meters and the presence of warm Atlantic Water may not assist to develop the intensive vertical convection to the bottom. The oceanographic stations of $\mathrm{T}-3$ were located in the regions on the continental slope of the Canadian Archipelago and Alaska. The temperature-chlorinity relation of these data, some of which are occupied in the autumn-winter cooling season, did not show any evidence to support the vertical circulation theory of bottom water formation.

Accordingly, it is believed that the deep water in the Pacific side of the Arctic has largely a transitional nature; it is called the Lower Intermediate Water.

Figure 26 b suggests that in the Atlantic side mixing is likely taking place among the Arctic Surface Water, the Atlantic Water, and the Atlantic Upper Intermediate Water. At the same time in the Pacific side, the temperature-chlorinity relations between 100 and 500 meters (Figs. 25 and 26 b) indicate that there is a very slight influence of the Atlantic Upper Intermediate Water upon the mixing between the Cold Interlayer and the Atlantic'Water. In this case, the Deep Shelf Water which appeared at shallow T-3 stations does not seem to play an important role in the mixing between the Arctic Surface Water and the Atlantic Water; the Deep Shelf Water is very local.

In summarizing the discussion presented above, the water masses encountered in the Arctic Ocean are schematically illustrated on the $\mathrm{T}-\mathrm{Cl}$ diagram shown in Fig. 29. The representative properties of these water masses are presented in Table 9 , on the basis of results obtained at T-3 during 1959-1960. 
Table 11.

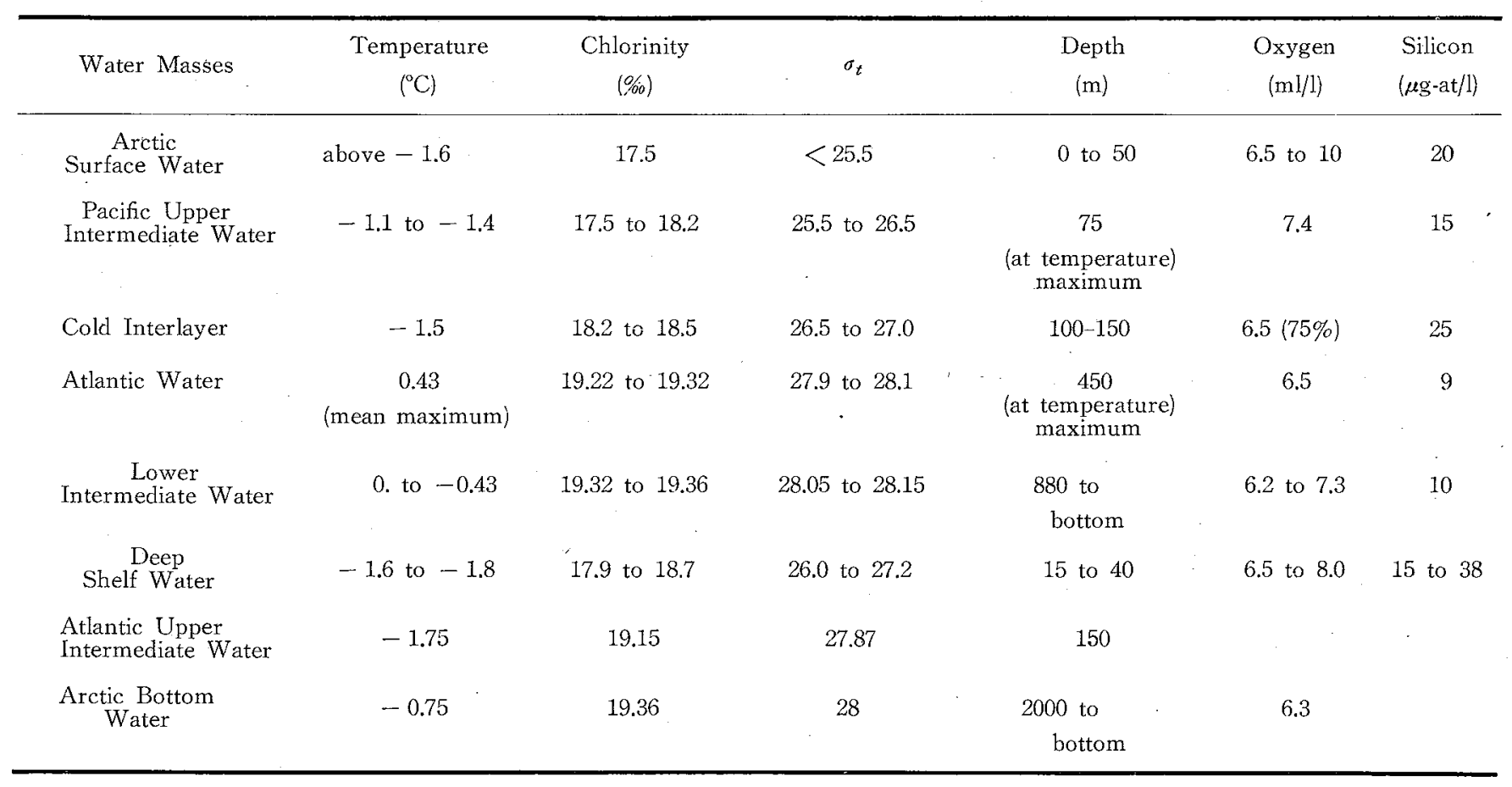




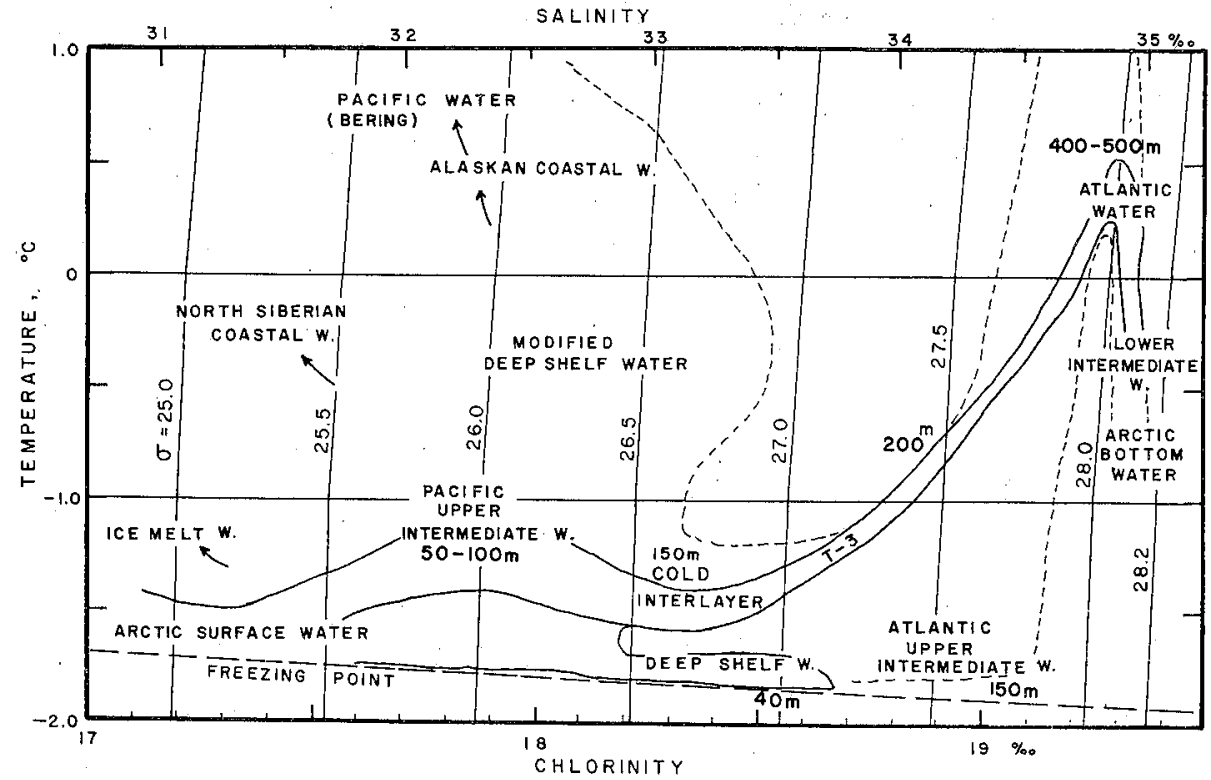

Fig. 29. Temperature-chlorinity relations of the water masses in the Arctic Ocean.

\section{Circulation in the Arctic Ocean}

In connection with the surface curent and the drift of sea ice in the Arctic Ocean, a number of reports have been presented by many investigators. The paths of the drift of vessels and ice islands shown in Fig. 2 will aid in comprehension of the surface circulation of the Arctic Ocean. The main flow is directed from east to west; the outflux through the area between Greenland and Svalbard is conspicuous. It is also characteristic that there is a large anticyclonic circulation with a radius of 500$1000 \mathrm{~km}$ in the Pacific side.

The surface current system of the Arctic Ocean is ruled by the wind system over the Arctic, in conjunction with the influx of Atlantic water and Pacific water and the run-off of land waters. According to BUYNITZKIY (1957), the wind energy is almost consumed in the deformation of ice field (70-80\%), and the export of sea ice from the Arctic Basin to the Atlantic Ocean takes up the remaining energy. A theoretical treatment of steady drift of pack ice was presented by FEL'ZENBAUM (1958). He concluded that the general drift of ice comprises two types: the gradient drift and the wind drift, an average speed of $1.4 \mathrm{~km} /$ day and $1.1 \mathrm{~km} /$ day respectively. For the sake of practical purpose the so-called isobaric drift of pack ice is estimated from the sea-level pressure chart. The following equation proposed by ZUBOV is valid for the Arctic:

$$
V=13000 \Delta P
$$


where $V$ is the speed of ice drift in $\mathrm{km} /$ month and $\Delta P$ is the pressure gradient in millibars per 1 kilometer.

The movement of large ice islands, which have a very deep draught, will be more affected by the ocean currents than the sea ice under the influence of local wind variation. The average drift speed of $\mathrm{T}-3$ over a considerably large distance is indicated below :

Period

$$
\begin{array}{rll}
\text { Apr. } & \text { 1952-Apr. } & 1953 \\
\text { Apr. } & \text { 1953-Apr. } & 1954 \\
\text { May } & 1954-\text { May } & 1955 \\
\text { May. } & 1955 \text {-Sept. } 1955 \\
\text { Apr. } & 1957-A p r . & 1959 \\
& 1959-1960 \\
6 & \text { June-10 } & \\
20 & \text { Sept.-20 } & \text { Nov. } \\
20 & \text { Nov. -10 } & \text { Feb. '60 } \\
10 & \text { Feb. }-4 & \text { May }
\end{array}
$$

\begin{tabular}{|c|c|c|c|c|c|c|c|}
\hline \multicolumn{6}{|c|}{ Intervals of drift } & \multicolumn{2}{|l|}{ Speed } \\
\hline \multicolumn{3}{|c|}{ Start } & \multicolumn{3}{|c|}{ Finish } & nautical miles/day & $\mathrm{cm} / \mathrm{sec}$ \\
\hline \multicolumn{8}{|c|}{1959} \\
\hline $0430 \%$ & Nov. & 14 & 0730 & Nov. & 17 & 6.7 & 14 \\
\hline 0730 & Nov. & 17 & 0400 & Nov. & 19 & 12.5 & 27 \\
\hline 0615 & Nov. & 27 & 0900 & Dec. & 3 & 5.9 & 13 \\
\hline 0430 & Dec. & 4 & 0215 & Dec. & 11 & 3.1 & 6.7 \\
\hline \multicolumn{8}{|c|}{1960} \\
\hline 0415 & Jan. & 20 & 0630 & Jan. & 25 & 3.8 & 8.2 \\
\hline 0630 & Jan. & 25 & 0730 & Jan. & 30 & 2.9 & 6.2 \\
\hline 0730 & Jan. & 30 & 0515 & Feb. & 5 & 4.8 & 10 \\
\hline 0515 & Feb. & 5 & 0615 & Feb. & 7 & 14.6 & 31 \\
\hline 0615 & Feb. & 7 & 0445 & Feb. & 9 & 18.0 & 39 \\
\hline 0715 & Feb. & 18 & 0500 & Feb. & 20 & 16.3 & 35 \\
\hline 0500 & Feb. & 20 & 0530 & Feb. & 22 & 10.3 & 22 \\
\hline 0900 & Mar. & 22 & 0845 & Mar. & 24 & 10.8 & 23 \\
\hline
\end{tabular}

Speed

$\begin{array}{cc}\text { miles/day } & \mathrm{cm} / \mathrm{sec} \\ 0.66 & 1.4 \\ 0.22 & 0.47 \\ 0.21 & 0.44 \\ 0.71 & 1.5 \\ 0.8 & 1.7 \\ & \\ 1.3 & 2.8 \\ 2.5 & 5.4 \\ 1.5 & 3.2 \\ 2.1 & 4.5\end{array}$

The average speed between April 1957 and April 1959 was 0.8 miles/day (1.7 $\mathrm{cm} / \mathrm{sec})$, which is about a half of the drift speed of $1.8 \mathrm{miles} /$ day $(3.8 \mathrm{~cm} / \mathrm{sec})$ during 1959-1960. Exceptionally large fluctuations in drift velocity were noticed during and after the blizzards. These are shown in Table 12 .

Table 12. Drift speed of Ice Island T-3 during blizzards

* Time in GMT. 
The values of drift speed were obtained from the astro-fixed positions of Ice Island T-3. It is, therefore, to be noted that minor fluctuations in velocity should be included in the drift intervals presented in Table 12. At the time of present writing the meteorological data were not available, thus the discussion on the drift of ice island in terms of wind (wind coeffieient and the angle of deviation) could not be developed. The drift of T-3 between 1952 and 1954 was analyzed by BROWNE and CRARY (1958). The wind coefficient during this period was 0.0175 in the area north of $86^{\circ} \mathrm{N}$ and 0.0110 for the area in proximity to northern Ellesmere Island. The angle of deviation was between $30^{\circ}$ and $50^{\circ}$. The rotational motion of the island was also discussed. The present writer analyzed the drift of $T-3$ in $1952-1954$ and indicated the seasonal change in the values of wind coefficient, being 0.02 in summer and 0.01 in winter. With respect to the angle of deviation, the seasonal variation was less pronounced. These seasonal changes may have a close relation to the cencentration of pack ice around T-3 (KusUNOKI 1962).

In Fig. $30 \mathrm{a}, \mathrm{b}$ the vertical distribution of density along the section of longitude $145^{\circ} \mathrm{W}$ and the latitude $80^{\circ} \mathrm{N}$, respectively, are presented from the data obtained in

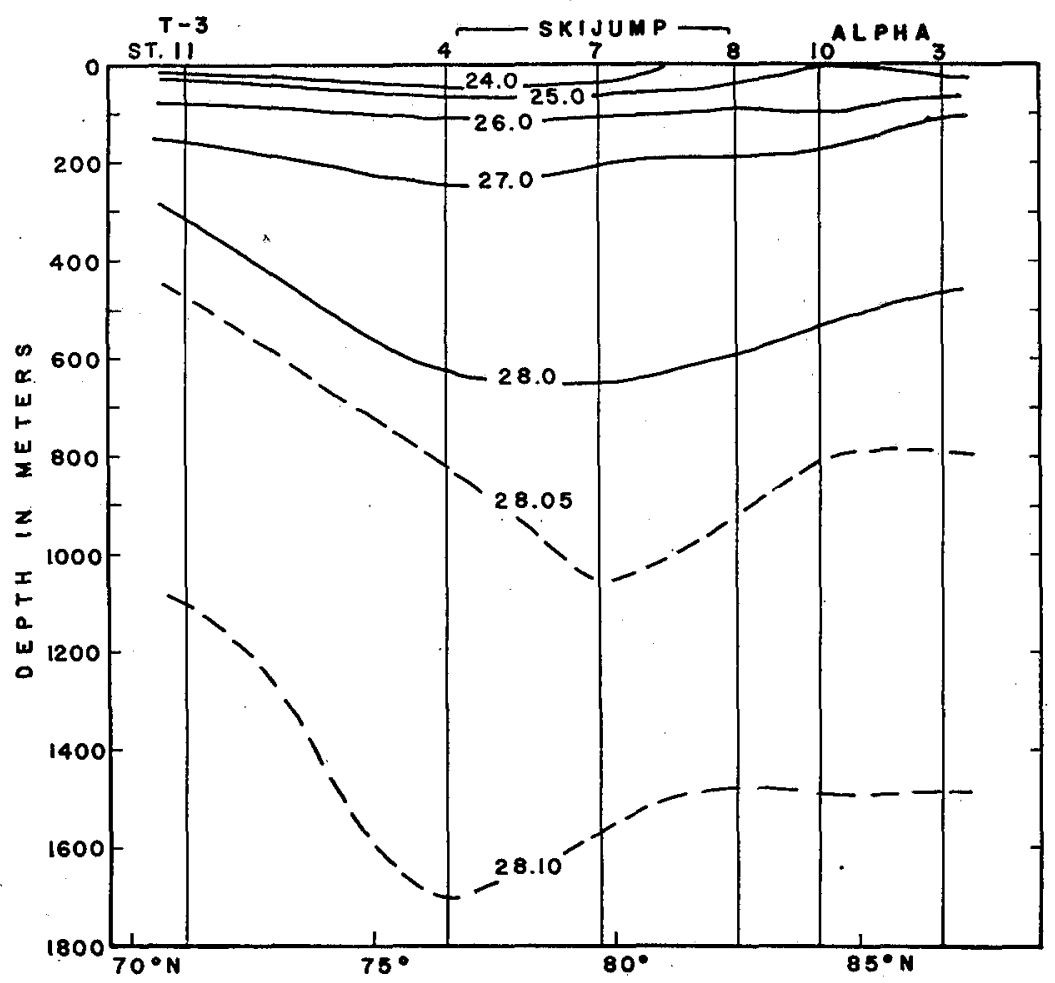

Fig. 30a. Density distribution in a vertical section along the $145^{\circ} \mathrm{W}$ meridian in the Pacific side of the Arctic Ocean. (Locations of stations are shown in Fig. 2). 
the Pacific side of the Arctic Ocean. It will easily be recognized that there exists an anticyclonic circulation in the Beaufort Basin: "Beaufort eddy". It is likely that this large eddy is governed by the relatively stable high pressure area over Northern Canada and Alaska. The considerable shifts in the position of the baric center may correlate with the drift of pack ice, divergence and convergence of ice field, and the outgoing of ice to the Greenland Sea.

The isopycnals in the deep water layers shown in Fig. $30 \mathrm{a}, \mathrm{b}$ do not coincide with level surfaces, which suggests that the anticyclonic eddy is maintained to a considerable depth, even below 1500 meters. HOLMES and WORTHINGTON (1953) pointed out that this eddy is maintained in part by frictional energy in conjunction with the inflow of Atlantic Water between Svalbard and Greenland. In was, however, noted that the inflow of Atlantic Water takes place in a manner of spreading rather than as the relatively narrow flow in the regions of the North Pole. No anticyclonic motion of Atlantic Water to drive the Beaufort eddy was recognized in the charts of horizontal distribution of temperatures of Atlantic Water presented by Russian authors. Recent studies on the drift of sea ice indicate that the atmospheric high pressure over the

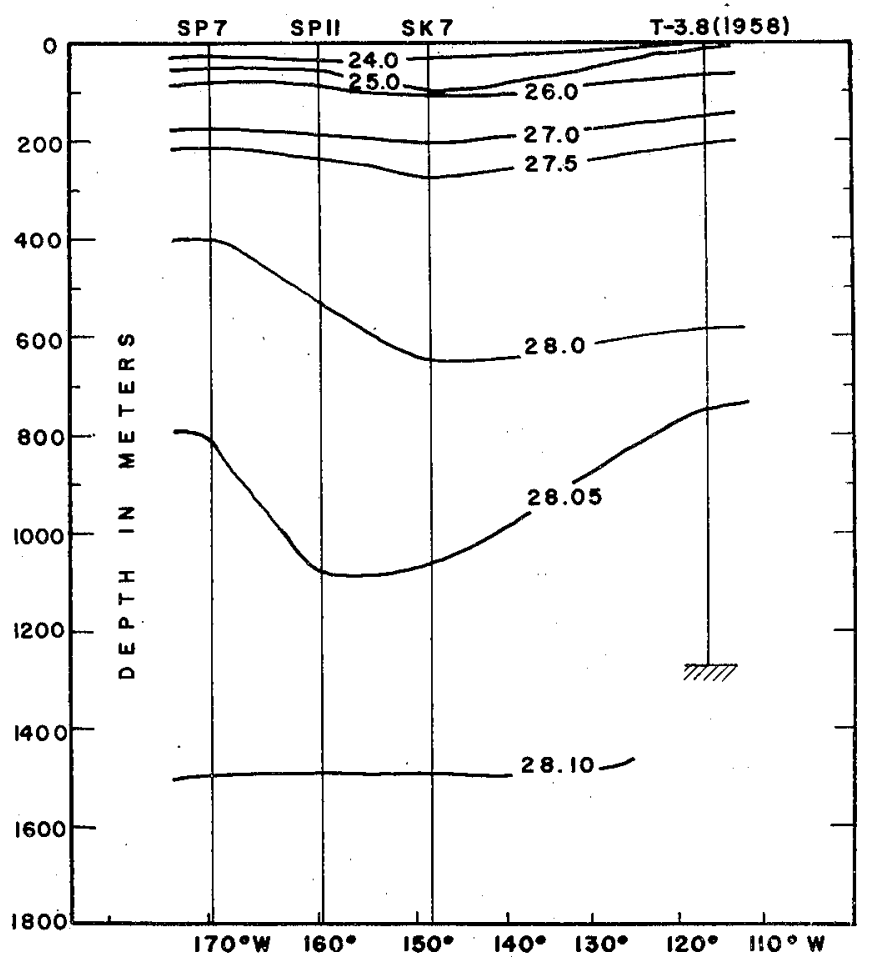

Fig. 30b. Density distribution in a vertical section along latitude $80^{\circ} \mathrm{N}$. (Locations of the atations are shown in Fig. 2). 
Canadian Archipelago has an important part in maintaining this anticyclonic circulation (DROGAYTSEV 1958). In the computation of drif of ice DROGAYTSEV assumed the lateral eddy viscosity of $8 \times 10^{\circ}$ (c.g.s,) and the wind stress curl was computed from the mean annual pressure map. No actual measurement of the movement of very deep water was made in the present observations on T-3 in 1950-1960 and at other part of the Arctic Ocean. According to the estimation of speed by the theorem of circulation, TrMOFEYEV (1960) stated that the speed at 75-250 meters to be $0.4-2.4$ $\mathrm{cm} / \mathrm{sec}$ and below this level $0.03-0.2 \mathrm{~cm} / \mathrm{sec}$, when taking the surface speed in a range of $2-12 \mathrm{~cm} / \mathrm{sec}$. He also computed that the complete renewal of Atlantic Water takes place within $6-7$ years $(3.8 \mathrm{~cm} / \mathrm{sec}$ or $1200 \mathrm{~km} / \mathrm{year}$ along the eastward route on the continental slope from Nansen Sill, Eurasia, America, Greenland to $20^{\circ} \mathrm{W}$ in longitude).

The oceanographic data obtained at T-3 in 1959-1960 have been combined with the data from other drift stations to compile the dynamic topography chart. The 600-dicibar surface was chosen as the motionless level in order to compare with the charts given by BROWNE and CRARY (1958), WORTHINGTON (1959), and BROWNE (1959), although the $\sigma_{t}$ surfaces are not horizontal even at 1800-decibar surface as shown in

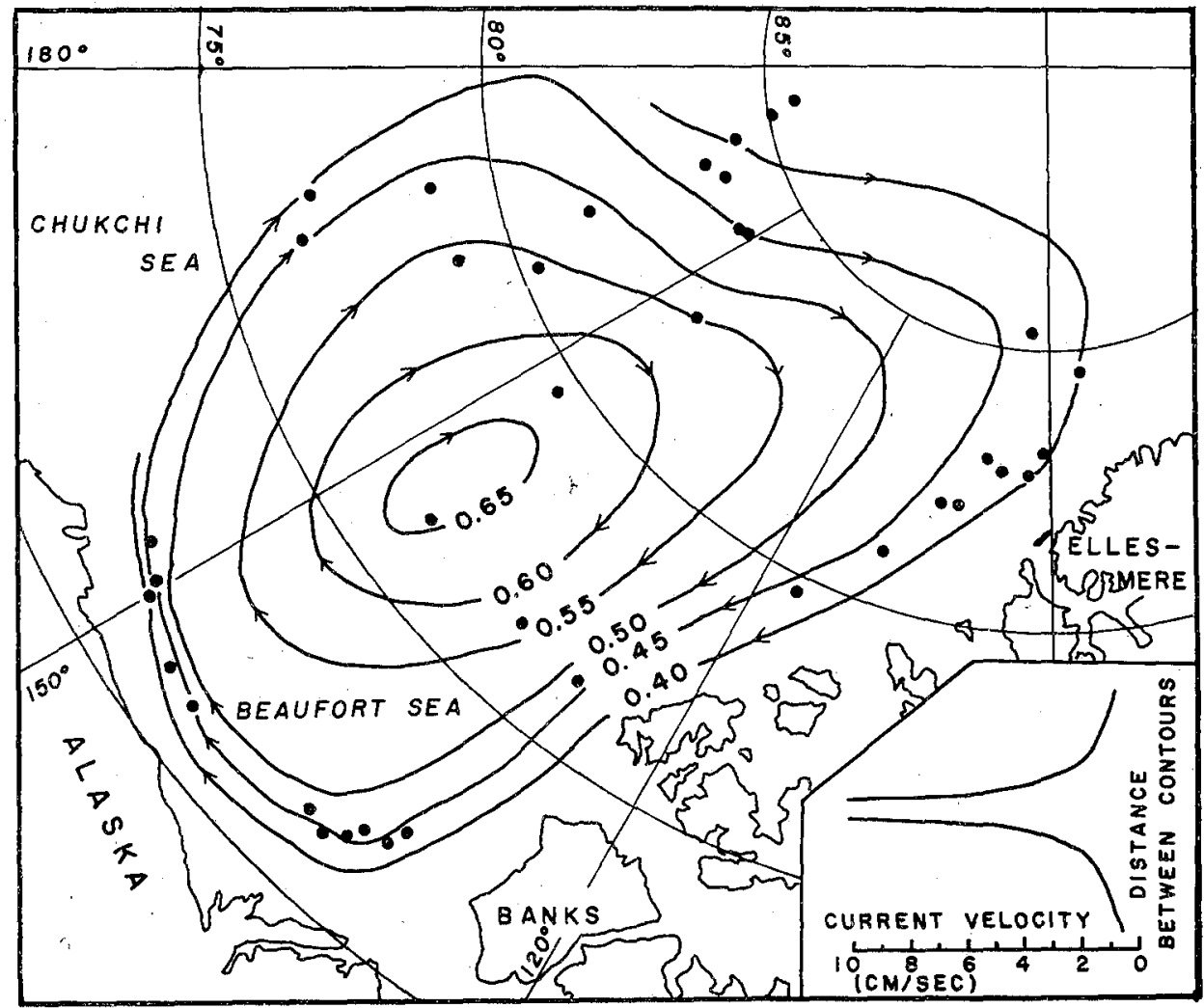

Fig. 31. Topography of the sea surface (dyn m) relative to the 600 -decibar surface. 
Figs. $30 \mathrm{a}$ and $30 \mathrm{~b}$. In Fig. 31 the data from stations at SP-2, Project Skijump, Drift Station Alpha, and T-3 are used.

The current profiles computed by dynamic consideration shows that a sharp decrease in current velocity exists at about 200 meters. In Fig. 32 three emamples of the vertical distribution of currents are presented. The computed current magnitudes normal to the section between St. 7 and St. 8 of T-3 (section $C$ in Fig. 32)

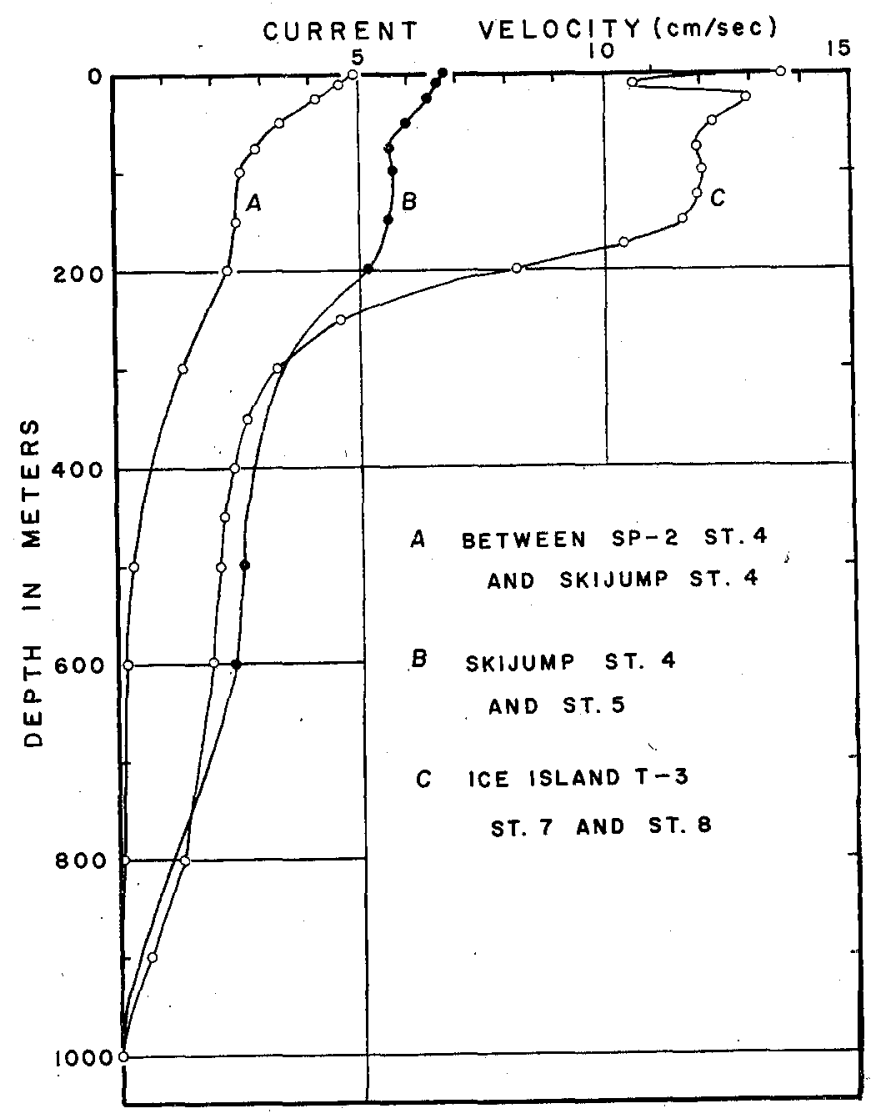

Fig. 32. Examples of the vertical distribution of current magnitude according to the dynamic computation.

are about $13 \mathrm{~cm} / \mathrm{sec}$ at the surface and about $8 \mathrm{~cm} / \mathrm{sec}$ at 200 meters, when the motionless layer was taken at 1000 meters. The surface velocity in the central area of the eddy (section B) is about $6 \mathrm{~cm} / \mathrm{sec}$ which is about half that for T-3. A minor decrease in current velocity between 50 and 100 meters is evident in the section $\mathrm{C}$ of Fig. 32, however, as yet, it is not fully understood whether or not this is due to the penetration of Pacific water at about 75 meters.

The volume transport of the Beaufort eddy through the section A (Fig. 32) is $5.8 \times 10^{6} \mathrm{~m}^{3} / \mathrm{sec}$, and almost the same value of $5.9 \times 10^{6} \mathrm{~m}^{3} / \mathrm{sec}$ was computed for the 
section between St. 16 of T-3 and St. 4 of Project Skijump. This transport of about $6 \times 10^{6} \mathrm{~m}^{3} / \mathrm{sec}$ is nearly equal to the influx of Atlantic Water between Faröe and Shetland. It is to be noted that the clockwise circulation of Beaufort eddy is opposite to the counter-clockwise movement of Atlantic Water deduced from the temperature data. If the latter scheme really exists in the Beaufort Sea, the volume transport of Beaufort eddy should be less than $6 \times 10^{6} \mathrm{~m}^{3} / \mathrm{sec}$.

The water and heat balance of the Arctic Ocean have been discussed by several authors (SVERDRUP et al 1942, ZUBOV 1945, DUNBAR 1960). It is needless to say that the estimation of the balance involves a great deal of uncertainty, not only in regard to the theoretical aspects, but also to the technical difficulties in observations under severe Arctic environment. The recent results presented by TIMOFEYEV (1960)* seem to summarized well the various primay estimates as are shown in Table 13.

Table 13. Annual water and heat balance of the Arctic Ocean (After Timofeyev 1960)

\begin{tabular}{|c|c|c|}
\hline Water Balance & Net Influf & Net Efflux \\
\hline Atlantic waters & $4.82 \times 10^{6} \mathrm{~m}^{3} / \mathrm{sec}$ & \\
\hline Bering Strait & 1.15 & \\
\hline Run-offs & 0.14 & \\
\hline Denmark Strait & & $5.10 \times 10^{6} \mathrm{~m}^{3} / \mathrm{sec}$ \\
\hline Canadian Arctic (residual) & & 1.01 \\
\hline Balances & 6.11 & 6.11 \\
\hline Heat Balance & $\cdot$ & \\
\hline Incoming & $\mathrm{kg} . \mathrm{cal} \times 10^{12}$ & $\%$ \\
\hline Ice formation $\left(2590 \mathrm{~km}^{3}\right)$ & 207,200 & 46 \\
\hline Atlantic water $\left(118,549 \mathrm{~km}^{3}\right)$ & 188,165 & 42 \\
\hline Pacific water $\left(36,125 \mathrm{~km}^{3}\right)$ & 33,490 & 8 \\
\hline \multirow[t]{2}{*}{ Run-off $\left(3700 \mathrm{~km}^{3}\right)$} & 17,102 & 4 \\
\hline & 445,957 & 100 \\
\hline \multicolumn{3}{|l|}{ Outgoing } \\
\hline $\begin{array}{l}\text { To atmosphere in peripheral seas } \\
\text { (assumed) }\end{array}$ & 259,891 & 58 \\
\hline $\begin{array}{l}\text { To atmosphere in the central } \\
\text { Arctic Basin }\end{array}$ & 133,359 & 30 \\
\hline To Greenland Sea & 52,707 & 12 \\
\hline & 445,957 & 100 \\
\hline
\end{tabular}

* Recently a well-summarized report on the water and heat balance of the Arctic Ocean was published by E. VowINCKEL and S. ORviG (Water balance and heat flux of the Arctic Ocean, Publ. in Meteorol. No. 44, Arctic Meteorology Research Group, McGill University 35 pp., .1961). 
The heat balance of the Arctic Ocean as was shown in Table 13 involves a variable factors to be estimated. It should be remarked that the heat exchange in the marginal seas along the Eurasian and American continents is left as the residual in Table 13. It should also be noted that the heat exchange between the water and the atmosphere is computed by a simple formula given by SHULEYKIN (1953): $q=0.03\left(t_{w}-t_{n}\right)$ $\mathrm{kg} . \mathrm{cal} / \mathrm{cm}^{2} /$ day, where $t_{r}$ is the temperature of sea water, and $t_{a}$ the air temperature. Hence the distribution of air temperature and the area of open water, as well as the formation and export of ice, should be accurately investigated.

The oceanographic observations made at $\mathrm{T}-3$ in $1959-1960$ are not sufficiently comprehensive to infer the mass and heat balance of the Arctic Ocean. It is believed, however, that these observations will greatly contribute to the construction of a more precise balance sheet when assembled with other pertinent data. Sufficient hydrometeorological data in order to evaluate the water and heat balance have been collected both spottily and sporadically, so that simultaneous and properly-spred oceanographic and meteorological observations in the Arctic Ocean must be carried out in order to amplify these data. In the light of recent activity of atomic icebreaker and submarines in the Arctic Ocean, the oceanographic work may be undertaken in the area unhumpered by the difficult accessibility of the former days.

\section{Conclusions}

The analysis of oceanographic data of the Arctic Ocean, particularly of the material collected on the Ice Island T-3 in 1959-1960, has been presented in this report. The data collected in the winter period at Ice Island $\mathrm{T}-3$ are of value in discussing the seasonal change of oceanographic conditions. In summarizing the description and discussions offered in the preceding chapters the following will be noted:

1. The temperature and chlorinity of the Arctic Ocean shows small change with respect to both locality and season, with the exception of the top layer.

2. The distribution of temperature showed the existence of relatively cold Surface Water, warm Atlantic Water with positive temperatures between 250 and 850-900 meters, and relatively cold deep water with negative temperatures at the stations taken on $\mathrm{T}-3$.

3. The surface water is heated in the summer season, sometimes the temperature exceeded $0^{\circ} \mathrm{C}$ and desalinification occurred due to the melting of snow and ice, partly influenced by the run-offs from the land. The advection and vertical convection within the surface layer at less than $30-50$ meters were discussed in relation to the ice formation and wind mixing during blizzards.

4. The penetration of Pacific Water, designated Pacific Upper Intermediate Water, was recognized in the southern and central parts of the Pacific side, being less pronounced in the offings of the Canadian Archipelago.

5. The distribution of chlorinity and density indicated stable stratification within 
the layers of less than 200-300 meters. Notwithstanding the penetration of warm Atlantic Water at subsurface layers, the vertical stability was almost positive through the water column from the surface to 2000 meters.

6. The oxygen content at the surface was in a range of $8-10 \mathrm{ml} / \mathrm{l}$ and decreased with depth. A minimum of $6.0 \mathrm{ml} / 1(74 \%)$ was characteristic at about 225 meters. A minor maximum of about $6.9 \mathrm{ml} / \mathrm{l}(85 \%)$ was recognized at 800 meters, even below this level the amount was more than $6 \mathrm{ml} / \mathrm{l}$ which is considerably larger than that in the Pacific and Atlantic Oceans. The oxygen content measured on the shallow continental shelf showed seasonal variation. A discussion was presented on the biological and physical factors which exert some influence upon the distribution of oxygen.

7. The content of silicate-silicon was considerably less than that in the seas of middle latitiudes. The surface water contained less silicon, with the exception of shallow shelf water. A pronounced maximum occurred at about 150 meters with an average value of $25 \mu \mathrm{g}$-atoms $/ \mathrm{l}$. On the basis of the concept of dynamic equilibrium, the presence of maximum and the vertical distribution of silicon were explained. The advective effect upon the distribution of silicon was attributed to the penetration of silicon-rich Pacific water. Annual variation in silicon in the euphotic layer was recognized at the stations on the continental shelf.

8. In summarizing the data of nutrient salts observed at $T-3$ since 1957 , the ratios of the amount of $\mathrm{Si}, \mathrm{N}$, and $\mathrm{P}$ are $12-15: 2-20: 1$.

9. Withe reference to the temperature, chlorinity, and other oceanographic elements, several correlation diagrams were presented for the analysis of water masses. In the Pacific side of the Arctic Ocean the following basic and local, and in some cases transitional, water masses are identified.

Arctic Surface Water: chracterized by low temperature at nearly freezing point and low chlorinity. The top layer is only summer-heated and tends to becomes fresh. This water is found at the levels less than 50 meters, with a range in chlorinity between 0 and $17.5 \%(\mathrm{~S}=31.6 \%)$. The increase in chlorinity within this layer is very remarkable, while the temperature remained near the freezing point. This water is originated by the run-off and precipitation in part, and is mixed with the Atlantic and Pacific water lying underneath.

Atlantic Water: found at about 450 meters in the southern Beaufort Sea with an average maximum temperature of $0.43^{\circ} \mathrm{C}$; the chlorinity was in a range of 19.22 $19.32 \%(\mathrm{~S}=34.72-34.90 \%)$. In analyzing temperature, counter-clockwise movement of Atlantic water was deduced.

Lower Intermediate Water: occupied the levels below 800-900 meters and is characterized by the negative temperatures between $0^{\circ}$ and $-0.4^{\circ} \mathrm{C}$. The chlorinity of this water ranged $19.32-19.36 \%(S=34.90-34.98)$, with the density of $28.1 \pm 0.05$. A minimum temperature of about $-0.4^{\circ} \mathrm{C}$ was observed at about 2000 meters. In contrast to the bottom water in the Atlantic side bounded by the Lomonosov Range, the temperature in the deep layers of the Pacific side is exceedingly high. Hence the 
waters occupying the Beaufort Deep are deduced to be transitional in nature between the Atlantic Water and the proper Arctic Bottom Water in the Atlantic side. The effective sill depth of the Lomonov Range was estimated to be 1300 meters.

Pacific Upper Intermediate Water: distinct at a depth of 75 meters has relatively warm temperatures. The temperature-chlorinity correlation of waters in Bering Strait, Chukchi and Beaufort Seas indicated the penetration of Pacific water into the Arctic Ocean, particularly directed to the North Pole, along the quasi-isentropic surface of $26.0 \pm 0.5$.

Cold Interlayer: occupies the lower part of the halocline zone between 100 and 150 meters. Its temperature minimum of -1.3 to $-1.5^{\circ} \mathrm{C}$ occurs at about 150 meters $\left(\mathrm{Cl}=18.2-18.5, \sigma_{t}=26.5-27.0\right)$. This layer presumably originates in the region north of Ellesmere Island, flowing southward along the periphery of Beaufort eddy.

Deep Shelf Water: found at the bottom of the stations occupied on the continental shelf. This water has a.low temperature of nearly freezing point and a chlorinity of $17.9-18.7 \%(\mathrm{~S}=32.34-33.78 \%)$. This is interpreted as winter-cooled Arctic Surface Water and the increase in chlorinity is attributed to the thermohaline convection due to ice formation.

Atlantic Upper Intermediate Water: observed in the Eurasian shelf waters has a temperature of $-1.75^{\circ} \mathrm{C}$ and a relatively high chlorinity of $19.15 \%(\mathrm{~S}=34.60 \%)$. This water may have originated from the winter cooling and may be admixed with haline Atlantic Water.

The sub-classification of Arctic Surface Water presented by LAFOND and others is applicable to the regions covered by the drift of $T-3$ in 1959-1960, where the Ice Melt Water and the Modified Deep Shelf Water were found during the course of the present observations.

The Water masses mentioned above are to be found for the most part in the central Arctic Basin, with the exception of the marginal shallow seas.

10. The drift of Ice Island T-3 during 1959-1960 was in a clockwise direction along the continental slope of North American Continent. The speed of drift should be taken as the average surface current existing permanently; the speed ranged 1.9 to $5.5 \mathrm{~cm} / \mathrm{sec}$ between. June 1959 and May 1960. The rapid drift of $40 \mathrm{~cm} / \mathrm{sec}$ was encountered during a strong blizzard in the winter season.

11. The presence of large Beaufort eddy in the Pacific side of the Arctic Ocean was indicated in compiling the dynamic anomaly chart relative to 600 -decibar surface. The role of atmospheric pressure distribution over the Arctic Ocean should not be ignored in sustaining the Beaufort eddy, carrying a volume of about $6 \times 10^{6} \mathrm{~m}^{3} / \mathrm{sec}$ or $190,000 \mathrm{~km}^{3} /$ year estimated by dynamic computation. The dynamic computation shows that the main fiow of the Beaufort eddy is limited to the upper layers of less than 200 meters, when the level of no-motion is taken at 1000 meters.

12. Survey of the literature on the water and heat budget of the Arctic Ocean suggests that the total balances are $6.1 \times 10^{6} \mathrm{~m}^{3} / \mathrm{sec}$ or $193,000 \mathrm{~km}^{3} / \mathrm{year}$ and $450,000 \times$ 
$10^{12} \mathrm{~kg} . \mathrm{cal} /$ year respectively.

\section{Acknowledgments}

The author is deeply indebted to the late Professor Ukichiro Nakaya for his encouragement. The useful suggestion and encouragement of Professor Takaharu Fukutomi of the Department of Geophysics at Hokkaido University are gratefully acknowledged. Special thanks are due to Dr. Keiji Higuchi and Mr. Jiro Muguruma for their untiring collaboration and companionship at the Drift Station on Ice Island T-3. Thanks are also due to many civilian and military personnel at the station, for their cooperation and assistance. Appreciation is expressed to the Terrestrial Sciences Laboratory, Geophysics Research Directorate, AFCRL, and to the Arctic Institute of North America.

\section{References}

AnTonov, V. S. 1958 Rol' materikovogo stoka v rezhime techeniy Severnogo Ledovitogo okeane. Problemy Severa, 1, 52-64.

Apollonio, S. 1958 Hydrobiological measurements on T3, 1957-1958. Woods Hole Ocean. Inst., $7 \mathrm{pp}$. (unpublished report).

BRodskry, K. A. 1956 Zhizn' v tolshche vody polyarnogo basseyna. Priroda, 45, No. $5,41-48$.

BROWNE, I. M. 1959 Ice drift in the Arctic Ocean. IGY Bulletin, 24, 5-10.

BROWNE, I. M. and CRARY, A. P. 1958 The movement of ice in the Arctic Ocean. Arctic Sea Ice (NAS-NRC Pub. 598), 191-208.

Bushnell, V. C. Ed. 1959- Scientific studies at Fletcher's Ice Island, T-3, 1952-1955. Geophysical Research Papers, No.63, Vol. I. 220 pp. (1959): Vol. II, 117 pp. (1959): Vol. III, 114 pp. (1960).

BuÝNITSKIY, V. Kh. 1957 O dreyfe l' dov v Arkticheskom basseyne. Geograf. sbornik, 12, 83-94.

Coachman, L. K. and Barnes, C. A. 1961 The contribution of Bering Sea water to the Arctic Ocean. Arctic. 14, No. 3, 147-161.

Collin, A. E. 1959 Canadian oceanographic activities on IGY Drift Station "Bravo". Fish. Res. Bd. Canada, Man. Rep. Series, No. 40, 34 pp.

CORTON, E. L. 1955 Climatology of the ice potential as applied to the Beaufort Sea and adjacent waters. U. S. Hydro. Office, Tech. Rep. No. 30, 16 pp.

CRARY, A. P. 1956 Arctic ice island research. Advances in Geophysics, 3, 1-42.

CRARY, A. P. 1958 Arctic ice island and ice shelf studies. Part I. Arctic, 11, No. 1, 3-42.

CRARY, A. P. 1960 Ibid. Part II. Arctic, 13, No. 1; 32-50.

CRARY, A. P. COTELl, R. D. and SeXton, T. F. 1952 Preliminary report on scientific work on "Fletcher's Ice Island", T3. Arctic, 5, No. 4, 211-223.

Drogartsev, D. A. 1958 Vetrovyye techeniya v Severnom Ledovitom okeane. Problemy Severa, 2, 5-15.

DUnbar, M. J. 1960 On the Bering Strait scheme. Polar Notes, No. 2, 1-18.

FARLOW III, J. S. 1958 Project Ice Skate oceanographic data. Woods Hole Ocean. Inst. 
Ref. No. 58-28, 18pp.

FEL'zenbaum, A. I. 1958 Teoriya ustanovivshegosya dreyfa l'dov i raschet srednego mnogoletnego dreyfa $\mathrm{v}$ tsentral'noy chasti Arkticheskogo basseyna. Problemy Severa, 2, 16-46.

Fukutomi, T., Kusunoki, K. and Tabata, T. 1950) Study of sea-ice (8): On the vertical distribution of temperature and salinity of sea water under the coastal ice at Abashiri and Monbetsu, Teion-kagaku (Low Temperature Science), 3, 193-206. (In Japanese).

GiletTi, B. J. and KuLP, J. L. 1959 Tritium observations. In: Scientific studies at Fletcher's Ice Island, T-3 (1952-1955). Geophys. Res. Pap. No. 63, I, 153-158.

GORDIYENKo, P. A. and LAKTIONOV, A. F. 1960 Glavnyye rezul'taty noveyshikh okeanograficheskikh issledovaniy v Arkticheskom basseyne. Izv. Akad. Nauk SSSR, Ser. Geogr., 5, 22-33.

Gudkovich, Z. M. 1955 Results of a preliminary analysis of the deep-water hydrological observations. In: Materialy nablyudeniy nauchno-issledovatel'skoy dreyfuyushchey stantsii 1950/51 goda, ed. M. M. Somov, Leningrad, Izdat. Morskoi Transport, 1954-1955, Vol. I, 41-46. (Transl. by Amer. Met. Soc.).

Holmes, J.F., and Wortitington, L. V. 1953 Oceanographic studies on Project Skijump II. Woods. Hole Ocean. Inst., Ref. No. 53-23, 11 pp.

Koenig, L. S., Greenaway, K. R., Moira Dunbar, and Hattersley-Smith, G. 1952 Arctic ice islands. Arctic, 5, No. 2, 66-103.

KRISS, A. Ye. 1955 Novyye mikrobiologicheskiye issledovaniya $v$ tsentral'noy arktike. Vestn. Akad. Nauk SSSR, 48, No. 9, 31-34.

KusUnOKI, K. 1955a Recent advances in the study of sea ice. Teion-kagaku, Ser. A, 14, 155-184. (In Japanese).

KUSUNOKI, K. $1955 \mathrm{~b}$ Observations on the horizontal and vertical distribution of chlorinity of sea ice. J. Oceanogr. Soc. Japan, 11, No. 4, 179-183.

KUSUNOKI K. 1960a Oceanographic observations on Ice Island $T-3$ in the summer of 1959. Arctic Inst. North Amer, Res. Pap. No. 10, 18 pp.

KUSUNOKI, K., $1960 \mathrm{~b}$ Ice islands in the Arctic Ocean. Kagaku (Science), 30, No. 2, 72-78. (In Japanese).

Kusunoki, K. 1962 On the drift of ice islands. Teion-Kagaku, A, 21 (In press).

Kusunoki, K. Muguruma, J. and Higuchi, K. 1962 Oceanographic observations at Ice Island ( $\mathrm{T}-3)$ in the Arctic Ocean in 1959-1960. Arctic Inst. North Amer., Res. Pap. No. 22, 110 pp.

IAFOND, E. C. 1954 Physical oceanography and submarine geology of the areas to the west and north of Alaska. Arctic, 7, No. 2, 93-101.

LAKTionov, A. F. 1959 Rel'yef dna Grenlandskogo morya v rayone poroga Nansena. Priroda, 48, No. 10, 95-97.

METCAIF, W. G. 1955 On the formation of bottom water in the Norwegian Basin. Trans. Amer. Geophys. Un., 36, No. 4, 596-600.

MoHr, J. L. 1959 Marine biological work. In : Scientific studies at Fletcher's Ice Island, T-3 (1952-1955). Geophys. Res. Pap. No. 63, I, 83-103.

MugurumA, J. 1961 Oceanographic observations on Fletcher's Ice Island (T-3), winter 1959-1960. Arctic Inst. North Amer., Res. Pap. No. 6, 18 pp. 
Musina, A. A. 1960 Gidrokhimicheskaya kharakteristika Arkticheskogo basseyna. Trud. Arkt. Antarkt. Nauch.-Issled. Inst., 218, 5-64.

Musina, A. A. and Avdeyevich, O. A. 1960 Sootnosheniye mezhdu solenost'yu i khlornost'yu $\mathrm{v}$ vode arkticheskikh morey. Trud. Arkt. Antarkt. Nauch.-Issled. Inst., 218, 110-124.

NAnSEn, F. 1902 The oceanography of the North Polar Basin. Norwegian North Polar Expedition 1893-1896, Sci. Res., 3, No. 9, 427 pp.

SaUer, J, F. T., TUliy, J. P. and LAFond, E. C. 1954 Oceanographic cruise to the Bering and Chukchi Seas, summer 1949: Pt. IV, Physical oceanographic studies. U. S. Navy Electronics Lab., Res, Rep. 416, Vol. 1, 31 pp.

Shuleykin, V. V. 1953 Fizika Morya. Moskva, Izdat. Akad. Nauk, 989 pp.

Sverdrup, H. U. 1950 Physical oceanography of the North Polar Sea. Arctic, 3, No. $3,178-186$.

Sverdpup, H. U., Jorinson, M. W. and Fleming, R. H. 1942 The Oceans. New York, Prentice-Hall. 1087 pp.

Trmofeyev, V. T. 1960 Vodnyye massy Arkticheskogo basseyna. Leningrad, Gidrometeoizdat. $190 \mathrm{pp}$.

U. S. Navy Hydrographic Office. 1958 Oceanographic Atlas of the Polar Seas, Part II : Arctic. Pub. No. 705, 149 pp.

Wortifington, L. V. 1953 Oceanographic results of Project Skijump I and II in the Polar Sea, 1951-1952. Trans. 'Amer. Geophys. Un., 34, No. 4, 543-551.

Worthington, L. V. 1959 Oceanographic observations. In: Scientific studies at Fletcher's Icc Island, T-3 (1952-1955). Geophys. Res. Pap. No. 63, I, 31-35.

ZuBov, N. N. 1945 L'dy Arktiki. Moskva. Izdat. Glavsevmorputi, 360 pp. 